\title{
AISLAMIENTO Y CARACTERIZACIÓN DE BACTERIAS LÁCTICAS ENOLÓGICAS PRODUCTORAS DE AMINAS BIÓGENAS
}

\section{TESIS}

QUE PARA OBTENER EL GRADO DE

MAESTRO EN BIOTECNOLOGÍA

PRESENTA

I. A. Luis Alberto Villarreal Sánchez

DIRECTOR

Dr. José Ramón Verde-Calvo

México, D. F., Septiembre 2014 
AISLAMIENTO Y

CARACTERTZACION DE BACTERTAS

LACTICAS ENOLOGICAS

BRODUCTORAS DE AMTNAS

BIOGENAS

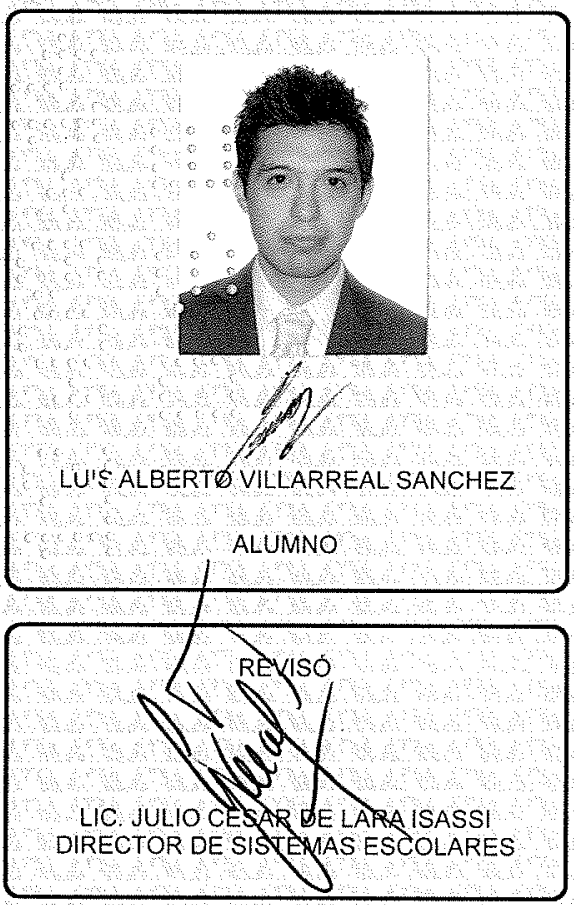

En México, D.F., se presentaron a las 10:00 horas del día 8 del mes de septiembre del año 2014 en la Unidad Iztapalapa de la. Universidad Autónoma Metropolitana, los suscritos miembros del jurado:

DR. FRANCISCO RUIZ TERAN

DR. HECTOR BERNARDO ESCALONA BUENDIA

M. EN E.P. FRIDA PURA MALPICA SANCHEZ

DRA. GABRIELA MARIANA RODRIGUEZ SERRANO

Bajola presidencia del primero y con caracter de Secretaria la última, se reunieron para proceder al Examen de Grado cuya denominación aparece al margen, para la obtención del grado de:

MAESTRO EN BIOTECNOLOGIA

$\mathrm{DE}:$ LUIS ALBERTO VILLARREAL SANCHEZ

y de acuerdo con el artículo 78 fracción III del Reglamento de Estudios Supexiores de la Universidad Autonoma Metropolitana, los miembros del jurado resolvieron

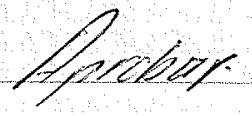

Acto continuo, el presidente del jurado comunicóal interesado el resultado de la evaluación y, en caso aprobatorio, le fue tomada la protesta.

DIRECTORA DE LA DIVISIOON DE CBS
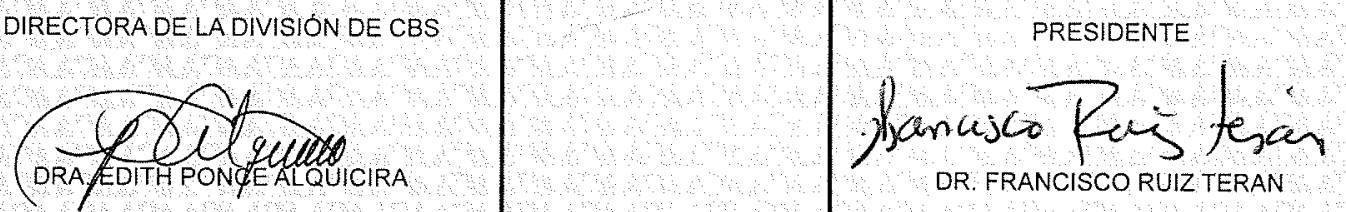

DR. FRANCISCO RUIZ TERAN
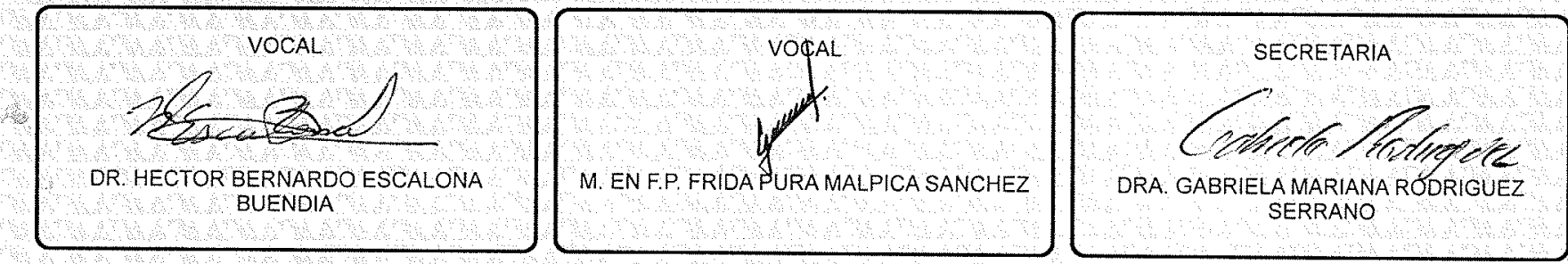



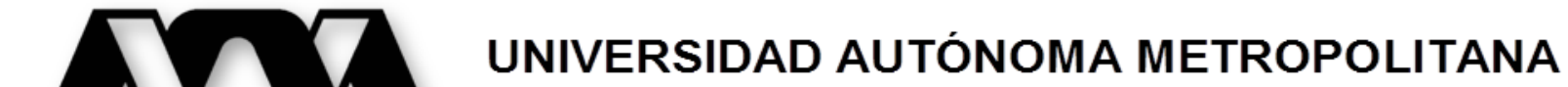 IZTAPALAPA}

DIVISIÓN DE CIENCIAS BIOLÓGICAS Y DE LA SALUD

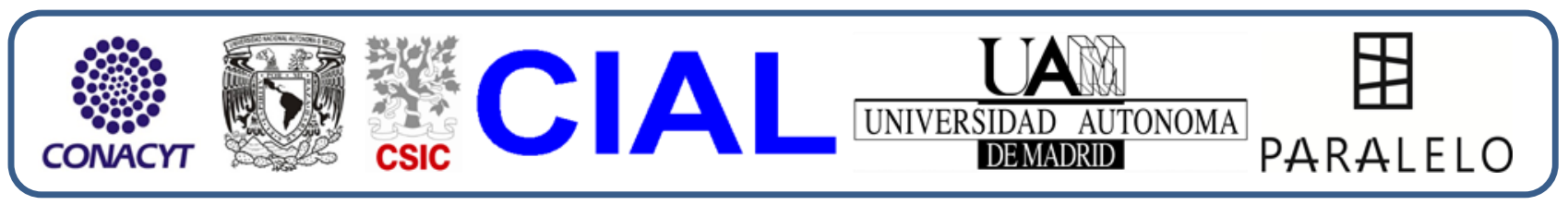

Agradezco al Consejo Nacional de Ciencia y Tecnología (CONACYT) por el apoyo otorgado en la realización del proyecto de Maestría en Biotecnología de la Universidad Autónoma Metropolitana, incluida en el Padrón Nacional de Posgrado de Calidad con No. de referencia 001465.

El presente trabajo se realizó en el Laboratorio de Enología del Departamento de Biotecnología de la Universidad Autónoma Metropolitana - Iztapalapa, haciendo mención especial a la Universidad Nacional Autónoma de México - Facultad de Química y la Universidad Autónoma de Madrid - Instituto de Investigaciones en Ciencias de la Alimentación por el agradecido respaldo durante el tiempo de estancia académica, así como a la bodega vinícola "Paralelo" por el apoyo en la obtención de muestras. 

México D.F., a 08 de septiembre de 2014

El jurado designado por la

División de Ciencias Biológicas y de la Salud de la Unidad Iztapalapa aprobó la tesis AISLAMIENTO Y CARACTERIZACIÓN DE BACTERIAS LÁCTICAS
ENOLÓGICAS PRODUCTORAS DE AMINAS BIÓGENAS

\author{
Que presentó \\ Luis Alberto Villarreal Sánchez \\ Comité Tutoral \\ Director: Dr. José Ramón Verde-Calvo (UAM - Dpto. Biotecnología) \\ Asesor: $\quad$ Dr. Héctor Escalona-Buendía (UAM - Dpto. Biotecnología) \\ Asesor: $\quad$ Dr. Francisco Ruiz-Terán (UNAM - Facultad de Química) \\ Jurado
}

Presidente: Dr. Francisco Ruiz Terán

Secretario: Dra. Gabriela Mariana Rodríguez Serrano

Vocal: $\quad$ Dr. Héctor Bernardo Escalona Buendía

Vocal: $\quad$ M. en F. P. Frida Pura Malpica Sánchez 

¿En qué reino, en qué siglo, bajo qué silenciosa conjunción de los astros, en qué secreto día que el mármol no ha salvado, surgió la valerosa y singular idea de inventar la alegría?

Con otoños de oro la inventaron. El vino fluye rojo a lo largo de las generaciones como el río del tiempo y en el arduo camino nos prodiga su música, su fuego y sus leones.

En la noche del júbilo o en la jornada adversa exalta la alegría o mitiga el espanto y el ditirambo nuevo que este día le canto otrora lo cantaron el árabe y el persa. Vino, enséñame el arte de ver mi propia historia como si ésta ya fuera ceniza en la memoria. 

A Cointa y Juan 



\section{AGRADECIMIENTOS}

Durante los dos años de posgrado tuve la oportunidad de conocer muchas personas que fueron un pilar para la elaboración de esta tesis;

Primeramente agradezco al Dr. Ramón por tenerme la confianza y el apoyo en este trabajo,

Al Dr. Héctor y al Dr. Francisco por asesorarme en cada obstáculo por pequeño que fuese,

A la Maestra Frida y a la Dra. Gabriela por sus observaciones y sugerencias,

A mis compañeros de generación por hacer más amenas las clases,

A mis compañeros de laboratorio (y de laboratorios vecinos), con quienes siempre puedo disfrutar mi día,

A mis compañeros de la UNAM; Jorge y Ana, quienes me enseñaron el mundo de la biología molecular,

A la Dra. Victoria, por brindarme la oportunidad de emprender una aventura inolvidable trabajando en el CIAL,

A Carol por asesorarme en cada paso durante mi trabajo en España,

A Irene y Ade, quienes con su carisma hacían mis días más amenos,

A Begoña, Ana, Fer, Tomás y todas las personas que conocí en el CIAL por su apoyo, consejos y enseñanzas,

A Susana Sierra y Thomas Egli por el apoyo para conseguir las muestras con las que se trabajó,

Y principalmente a mi familia, a Miriam y a mis amigos, quienes siempre han creído en mí y han estado apoyándome durante mi progreso profesional y personal. 



\section{RESUMEN}

Las aminas biógenas son compuestos orgánicos (bases nitrogenadas) de bajo peso molecular, frecuentemente encontradas en bebidas y alimentos fermentados, como quesos, embutidos, vegetales, pescados, cerveza, vino, entre otros. Su presencia se debe principalmente a bacterias ácido lácticas con capacidad para descarboxilar ciertos aminoácidos. Las características fisiológicas de las aminas son muy variadas, ya que son esenciales en las funciones biológicas del ser humano, sin embargo, su consumo en concentraciones altas puede producir algunos efectos perjudiciales a la salud.

Las aminas biógenas que se encuentran en mayor abundancia en el vino son la histamina, tiramina y putrescina, presentes en concentraciones que van desde trazas hasta decenas de $\mathrm{mg} / \mathrm{L}$, pudiendo causar algunas alteraciones fisiológicas (e. g. náuseas, sudoración, dolor de cabeza, enrojecimiento de piel, entre otras) principalmente en personas sensibles o intolerantes a dichos compuestos.

Este trabajo tuvo como objetivo detectar bacterias lácticas enológicas que fueran capaces de producir aminas biógenas identificándolas mediante espectrometría de masas MALDI-TOF. Como etapa inicial se aislaron 36 bacterias lácticas, caracterizando, a nivel de especie, diez de ellas y dos más de diferente origen; seis cepas del genero Lactobacillus (cuatro L. paracasei y dos L. brevis) y seis del género Enterococcus (E. faecium).

De 23 cepas lácticas estudiadas (entre las cuales cuatro L. paracasei y una $L$. brevis), ninguna presentó el gen $b d c$ A o sufI, responsables de producir y degradar histamina, respectivamente. Por otra parte, sobre las doce bacterias caracterizadas, se evaluó in vitro (i. e. medio de cultivo) la capacidad productora de aminas biógenas (histamina, tiramina y putrescina) detectando por RPHPLC que ninguna cepa produce histamina ni putrescina, sin embargo se encontró que las cepas de E. faecium y de L. brevis pueden llegar a ocasionar ciertos riesgos toxicológicos debido a su producción de tiramina.

Poco a poco diversos países han recomendado ciertos límites para aminas biógenas en vinos, lo cual puede llegar a interferir sobre las transacciones internacionales, es importante que México cuente con las bases científicas que le permitan sugerir y regir niveles de aminas seguros para el consumidor, por tal motivo se describe el primer trabajo sobre aminas biógenas en vino mexicano, con lo cual se pretende impulsar la investigación sobre este tema a nivel nacional y poder cumplir con las exigencias globales de calidad que se presentan día a día en el sector enológico. 



\begin{abstract}
Biogenic amines are organic compounds (nitrogen bases) of low molecular weight, frequently found in fermented beverages and foods such as cheese, sausage, vegetables, fish, beer and wine, inter alia. Their presence is mainly due to lactic acid bacteria capable to decarboxylate certain amino acids. The physiological characteristics of the amines are varied, as they are essential for the biological functions of the human being, however, its consumption in high concentrations can cause some adverse health effects.

Biogenic amines that found in greater abundance in wine are histamine, tyramine and putrescine, present in concentrations ranging from trace amounts to tens of $\mathrm{mg} / \mathrm{L}$, which may cause some physiological disorders (e. g. nausea, sweating, headache and hyper or hypotension, inter alia) mainly in sensitive or intolerant people to such compounds.

This study aimed to detect oenological lactic acid bacteria able to produce biogenic amines identifying them by mass spectrometry MALDI-TOF. As an initial step, 36 lactic acid bacteria were isolated, characterizing, at the species level, ten of them and two others from different sources; six strains of the genus Lactobacillus (four L. paracasei and two L. brevis) and six of the genus Enterococcus (E. faecium).

None of 23 lactic strains studied (among which four $L$. paracasei and $L$. brevis) presented the $b d c \mathrm{~A}$ or sufI gene responsible for producing and degrade histamine, respectively. Moreover, the producing ability of biogenic amines (histamine, tyramine and putrescine) of the twelve bacteria characterized was evaluated in vitro (i. e. growth medium), it was detected by RP-HPLC that no strain occurs histamine and putrescine, however it was found strains of $E$. faecium and $L$. brevis can potentially cause certain toxicological risks due to their production of tyramine.

Gradually several countries have recommended limits for biogenic amines in wines, which can interfere on international transactions, it is important for Mexico to have the scientific basis to enable it to suggest and rule safe levels of amines to the consumer, by this reason the first work on biogenic amines in Mexican wine is described, which is designed to promote research on this issue nationally and to meet global quality requirements are presented daily in the field of oenology.
\end{abstract}





\section{CONTENIDO}

INTRODUCCIÓN ......................................................................................... 1

CAPÍTULO 1 MARCO TEÓRICO _............................................................................... 5

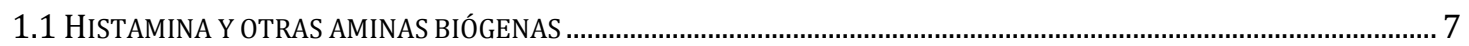

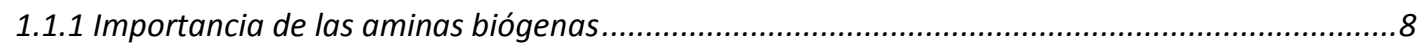

1.1.1.1 Funciones fisiológicas de la histamina y su intolerancia ............................................................ 9

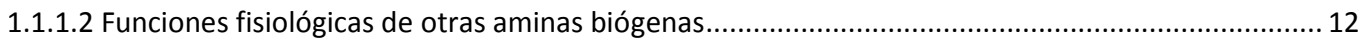

1.1.2 Antecedentes de aminas biógenas en alimentos y bebidas ..................................................12

1.1.3 Antecedentes de histamina y otras aminas biógenas en vino...................................................

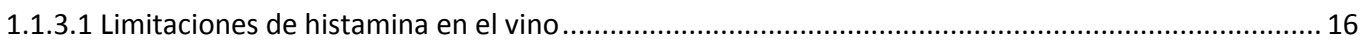

1.1.3.2 Factores enológicos que afectan la presencia de aminas biógenas................................................. 16

1.1.3.3 Técnicas para la detección de aminas biógenas en vinos ................................................................17

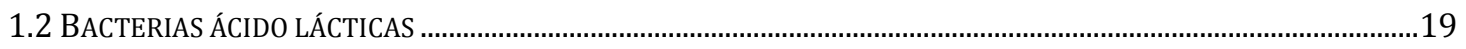

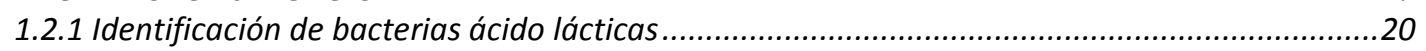

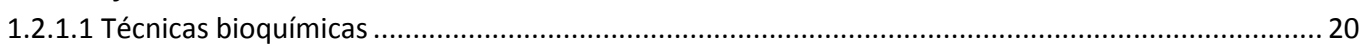

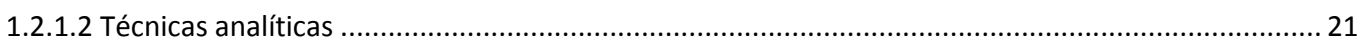

1.2.2 Importancia de bacterias ácido lácticas en la enología ..........................................................24

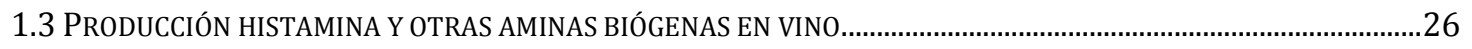

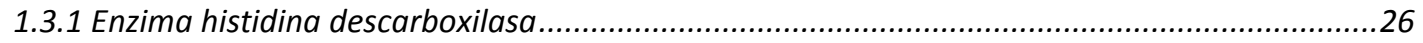

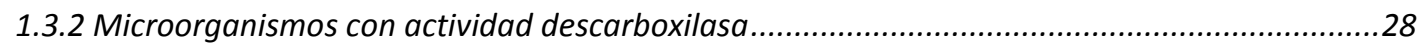

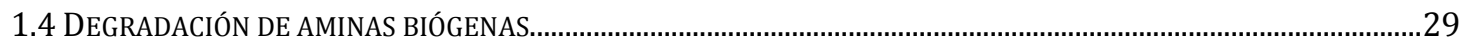

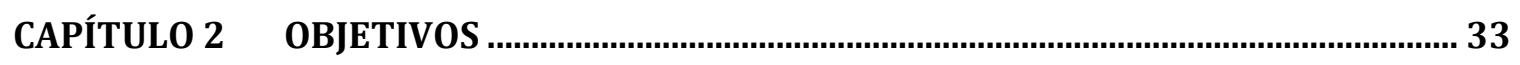

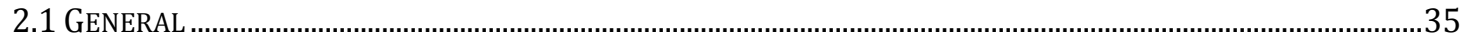

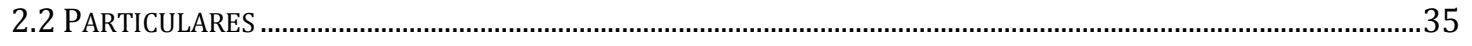

CAPÍTULO 3 JUSTIFICACIÓN .................................................................................... 37

CAPÍTULO 4 MATERIALES Y MÉTODOS …….................................................................. 41

4.1 AISLAMIENTO DE BACTERIAS ÁCIDO LÁCTICAS ………….................................................................................. 43

4.2 IDENTIFICACIÓN DE BACTERIAS ÁCIDO LÁCTICAS.............................................................................................45

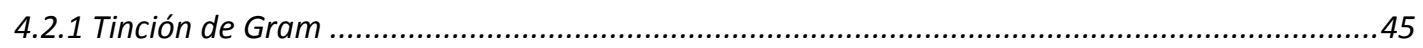

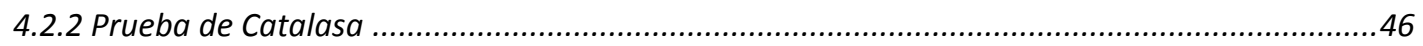

4.3 CARACTERIZACIÓN DE BACTERIAS ÁCIDO LÁCTICAS (MALDI-TOF/MS) …………......................................... 46

4.4 ESTUDIO DE LA INFLUENCIA SOBRE LA PRESENCIA DE AMINAS BIÓGENAS ..........................................................49

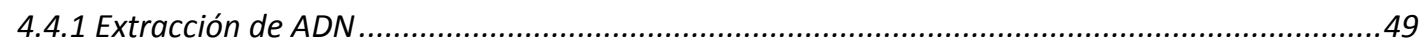

4.4.2 Detección de genes que influyen en la presencia de histamina ...............................................50

4.4.3 Producción de aminas biógenas en medio de cultivo .............................................................51

4.4.4 Determinación de aminas (RP-HPLC-Fluorescencia) ............................................................52

CAPÍTULO 5 RESULTADOS/ DISCUSIÓN .................................................................. 55

5.1 AISLAMIENTO E IDENTIFICACIÓN DE BACTERIAS ÁCIDO LÁCTICAS........................................................................57

5.2 CARACTERIZACIÓN DE BACTERIAS ÁCIDO LÁCTICAS...........................................................................................59

5.3 INFLUENCIA DE BACTERIAS ÁCIDO LÁCTICAS SOBRE LAS AMINAS BIÓGENAS....................................................61

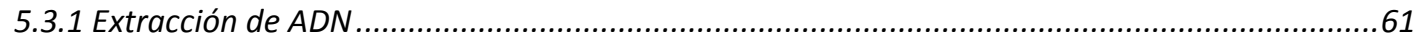

5.3.2 Detección de genes que influyen en la presencia de histamina ................................................62

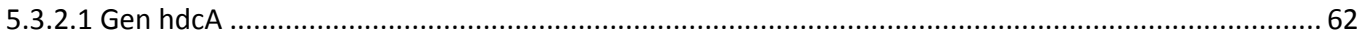

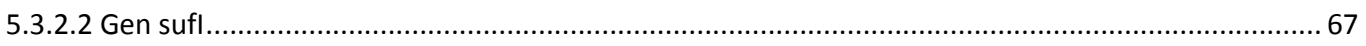

5.3.3 Producción de aminas biógenas en medio de cultivo ...............................................................69

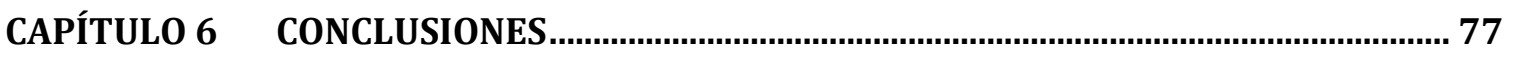

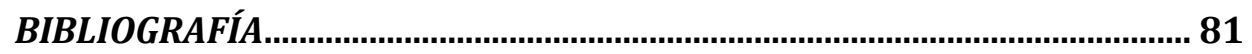





\section{ÍNDICE DE TABLAS}

TABLA 1. EFECTOS CLÍNICOS DE ACUERDO A LA CONCENTRACIÓN DE HISTAMINA EN PLASMA..................................................11

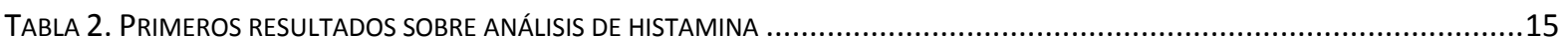

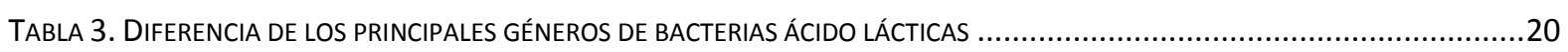

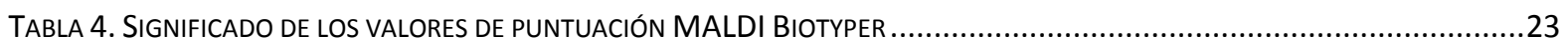

TABLA 5. BACTERIAS ELEGIDAS PARA CARACTERIZACIÓN MEDIANTE MALDI-TOF/MS .................................................46

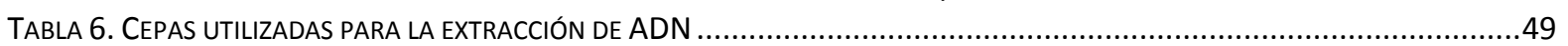

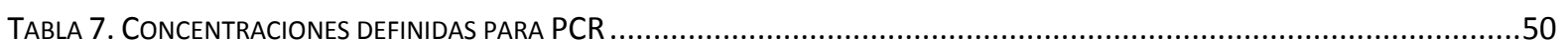

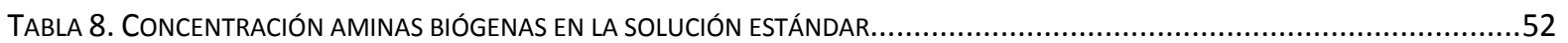

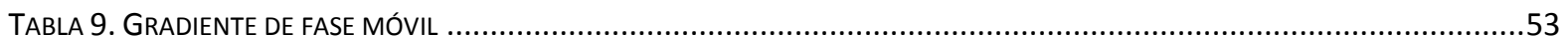

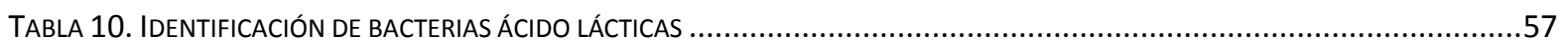

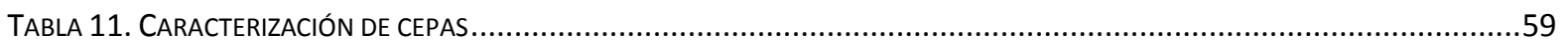

TABLA 12. PUBLICACIONES CON CEPAS ENOLÓGICAS DE L. BREVIS, L. PARACASEI Y E. FAECIUM ...........................................60

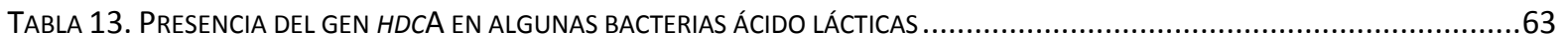

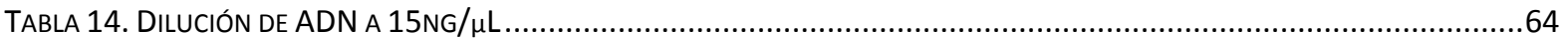

TABLA 15. PRIMERS PARA LA DETECCIÓN DE BACTERIAS ENOLÓGICAS CAPACES DE PRODUCIR HISTAMINA .................................65

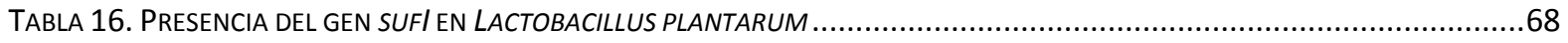

TABLA 17. PARÁMETROS CROMATOGRÁFICOS DE AMINAS BIÓGENAS .......................................................................69

TABLA 18. COLECCIÓN DE CEPAS CARACTERIZADAS Y SU ACTIVIDAD PRODUCTORA DE AMINAS BIÓGENAS .................................72 



\section{ÍNDICE DE FIGURAS}

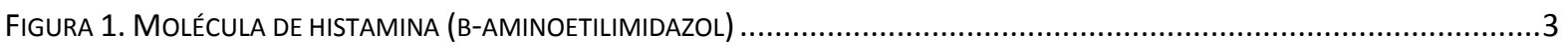

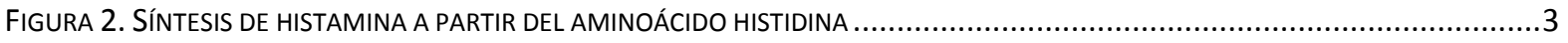

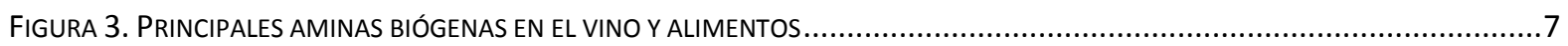

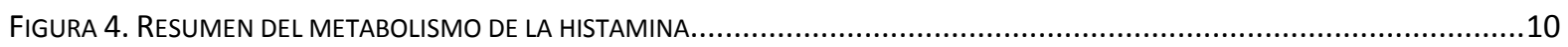

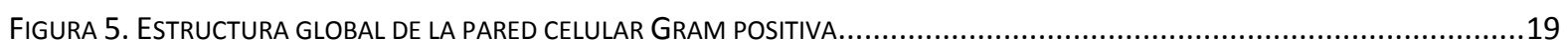

FIGURA 6. PRUEBAS BIOQUÍMICAS PARA LA DETECCIÓN DE BACTERIAS ÁCIDO LÁCTICAS...................................................21

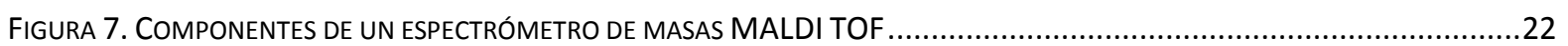

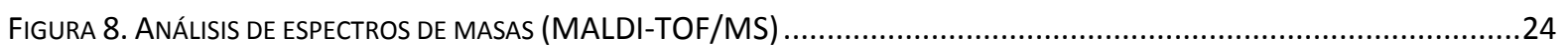

FIGURA 9. CINÉTICA DE LEVADURAS Y BACTERIAS ÁCIDO LÁCTICAS DURANTE LA VINIFICACIÓN .............................................25

FIGURA 10. ESQUEMA DE LA FERMENTACIÓN MALOLÁCTICA POR BACTERIAS ÁCIDO LÁCTICAS ..............................................25

FIGURA 11. MECANISMO DE REACCIÓN PROPUESTO PARA LA DESCARBOXILACIÓN DE HISTIDINA.........................................27

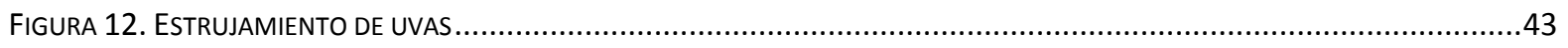

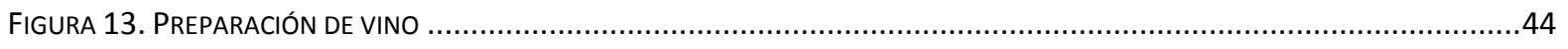

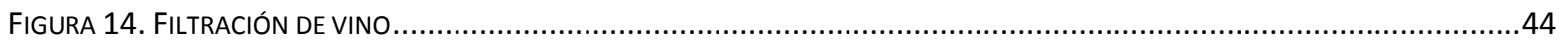

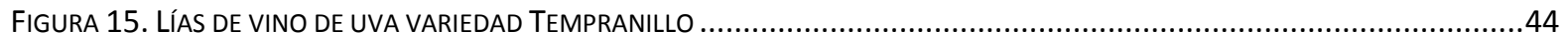

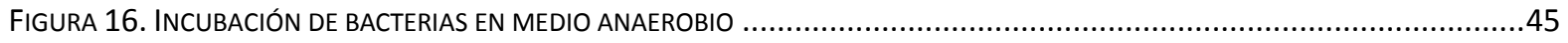

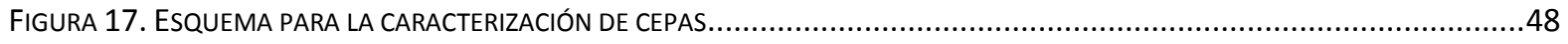

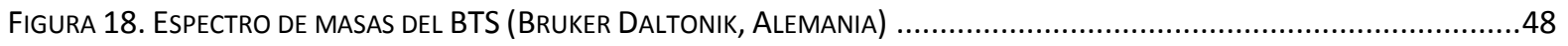

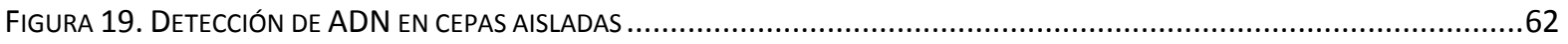

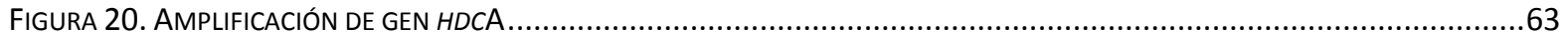

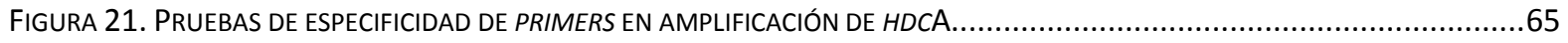

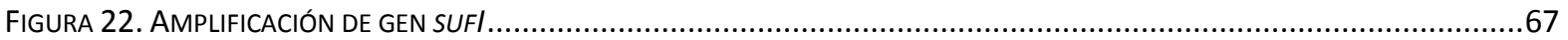

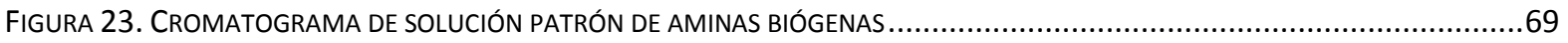

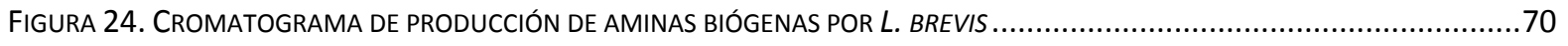

FIGURA 25. CROMATOGRAMA DE PRODUCCIÓN DE AMINAS BIÓGENAS POR E. FAECIUM..................................................71 



\section{ABREVIATURAS Y ACRÓNIMOS}

$\mathrm{AB}$

ADN

ARN

BAL

CECT

$\mathrm{DAO}$

EMP

EDTA

FML

GRAS

HDC

hdc

HNMT

HPLC

MALDI

MCE

MRS

MS

ODC

odc

OIV

OPA

PCR

PLP

RP-HPLC

TDC

tdc

TOF

UFC

UV
Amina(s) Biógena(s)

Ácido Desoxirribonucleico

Ácido Ribonucleico

Bacterias Ácido Lácticas

Colección Española de Cultivos Tipo

Diamino Oxidasa(s)

Vía Embden-Meyerhof-Parnas

Ácido etilendiaminotetraacético/Etbylenediaminetetraacetic acid

Fermentación Maloláctica

Generalmente Reconocido Como Seguro/Generally Recognized as Safe

Enzima Histidina Descarboxilasa/Histidine Decarboxylase Enąyme

Gen Histidina Descarboxilasa/Histidine Decarboxylase Gene

Histidina N-metil-transferasa

Cromatografía de Líquidos de Alta Eficacia/High Performance Liquid Chromatography

Desorción-Ionización Láser Asistida por Matriz/Matrix Assisted Laser DesorptionIonization

Mercaptoetanol/Mercaptoethanol

Medio de cultivo Man, Rogosa y Sharpe, para bacterias ácido lácticas

Espectrometría de Masas/Mass Spectrometry

Ornitina descarboxilasa

Gen Ornitina Descarboxilasa/Ornithine Decarboxylase Gene

Organización Internacional de la Viña y el Vino

Ortoftalaldehído/Ortho-phthalaldebyde

Reacción en Cadena de la Polimerasa/Polymerase Chain Reaction

Piridoxal-5-Fosfato

Cromatografía de Líquidos de Alta Eficacia en Fase Inversa/Reverse Phase High

Performance Liquid Chromatography

Enzima Tirosina Descarboxilasa/Tyrosine Decarboxylase Ensyme

Gen Tirosina Descarboxilasa/Tyrosine Decarboxylase Gene

Tiempo de Vuelo/Time of flight

Unidad(es) Formadora(s) de Colonia(s)

Ultra Violeta/Ultra Violet 



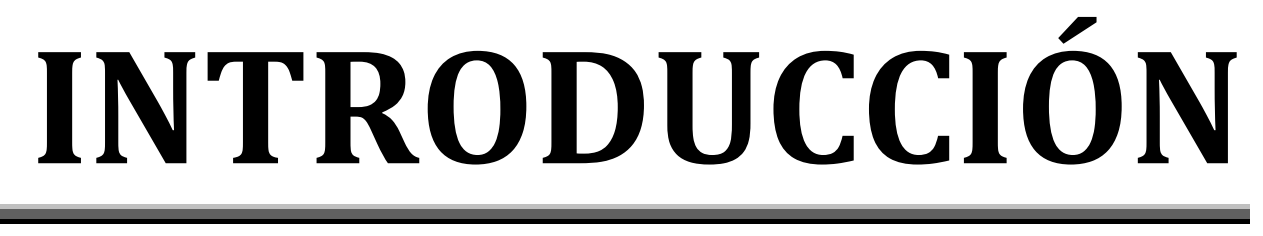



En años recientes se ha considerado retomar investigaciones dedicadas al estudio de aminas biógenas de carácter exógeno, las cuales se encuentran en diferentes alimentos y bebidas fermentadas. Éste tipo de compuestos pueden estar presentes de forma natural o pueden ser formados por microrganismos como consecuencia de la descarboxilación de aminoácidos presentes (Zee et al. 1983; Izquierdo-Pulido et al. 1989; Moret et al. 2005; Restuccia et al. 2011).

Las aminas biógenas son bases orgánicas de bajo peso molecular, tienen al menos un grupo amino y su origen es biológico a través de la acción enzimática, pueden ser de composición aromática, alifática o heterocíclica (Silla Santos 1996; Önal et al. 2013). Cuando estos compuestos químicos se encuentran en altas concentraciones pueden producir efectos fisiológicos indeseables en el consumidor como náuseas, dolores de cabeza, alteraciones respiratorias, enrojecimiento de la piel, palpitaciones cardíacas, híper o hipotensión y fenómenos de alergia. La mayoría de las intoxicaciones alimentarias se relacionan principalmente con la histamina (Marquardt \& Werringloer 1965; Landete 2005; Maintz \& Novak 2007; Garcia-Moruno \& Muñoz 2012), sin embargo también se ha estudiado la influencia organoléptica de otras aminas como la putrescina y cadaverina (Palacios et al. 2005). La histamina o $\beta$-aminoetilimidazol, amina heterocíclica, es una molécula hidrófila compuesta de un anillo imidazol y un grupo etilamina (Figura 1).

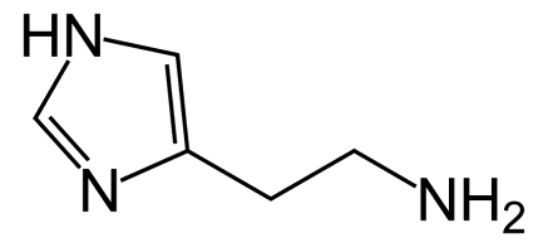

Figura 1. Molécula de histamina ( $\beta$-aminoetilimidazol)

La concentración de histamina en el vino depende de varios factores tales como la presencia de precursores aminoácidos (Soufleros et al. 1998), microorganismos que posean enzimas amino-descarboxilasas (Costantini et al. 2013) y condiciones ambientales específicas ( $\mathrm{pH}$, temperatura, presencia de $\mathrm{O}_{2}$, $\mathrm{SO}_{2}$, etc.) que favorezcan la descarboxilación del aminoácido histidina por la enzima histidina descarboxilasa y así producir histamina (Figura 2) (Schelp et al. 2001).
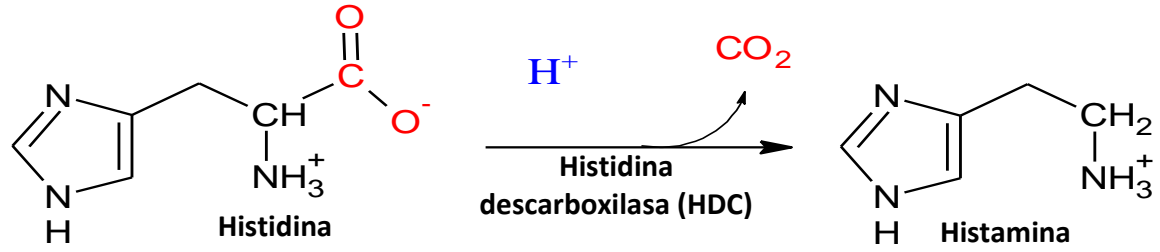

Figura 2. Síntesis de histamina a partir del aminoácido histidina 
Todos aquellos factores que afectan al crecimiento de los microorganismos enológicos (especialmente a aquellos que presentan actividad descarboxilasa) van a influir en la concentración de aminas presentes en el vino. Así, a $\mathrm{pH}$ bajos, concentraciones elevadas de $\mathrm{SO}_{2}$ y de etanol, además de la inoculación de cultivos seleccionados seguros van a limitar el desarrollo de estos microorganismos. Por el contrario, temperaturas elevadas, presencia de nutrientes en el mosto o vino (azúcares, aminoácidos, ácidos orgánicos metabolizables) y deficientes prácticas higiénicas potencian el crecimiento microbiano y aumentan el riesgo de elevadas concentraciones de aminas (Landete 2005). Los microorganismos autóctonos del vino son principalmente los responsables de la presencia de aminas biógenas, ya que se ha demostrado que los cultivos iniciadores malolácticos exógenos no poseen los genes codificantes a la histidina descarboxilasa y pueden controlar la producción de aminas biógenas durante la elaboración industrial del vino (Smit et al. 2013).

Principalmente la producción de aminas se lleva a cabo por microorganismos vivos de manera intracelular, sin embargo según (Coton, Rollan, Bertrand, et al. 1998), una vez que las células mueren y se lisan, las enzimas (amino descarboxilasas) son esparcidas al exterior siendo aún capaces de seguir produciendo aminas biógenas durante el envejecimiento del vino.

Conjuntamente con los efectos fisiológicos que se pueden presentar en las personas que ingieran vino, según Palacios et al. (2005), el desarrollo sin control de bacterias lácticas en el vino puede producir alteraciones en su calidad organoléptica, acción que causa el desagrado y rechazo de la bebida. 


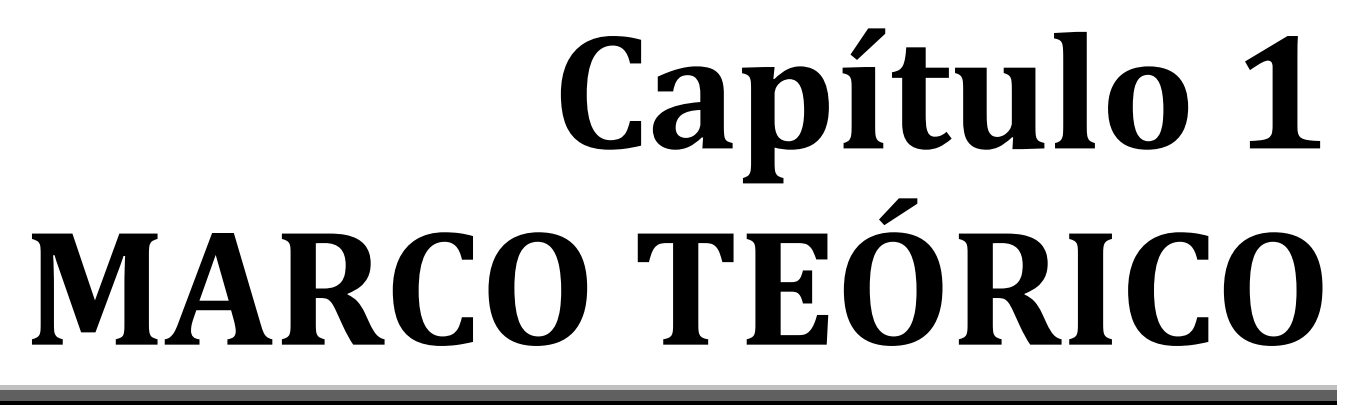





\subsection{Histamina y otras aminas biógenas}

Las aminas biógenas (AB) son bases nitrogenadas de bajo peso molecular, tienen al menos un grupo amino y su origen es biológico a través de la acción enzimática, pueden ser de composición aromática tales como la tiramina y la feniletilamina, alifática como putrescina y cadaverina o heterocíclica como la histamina y triptamina (Figura 3)(Silla Santos 1996; Önal et al. 2013), según el número de grupos amino se pueden clasificar como monoaminas (tiramina y feniletilamina), diaminas (putrescina y cadaverina) o poliaminas (espermina y espermidina) (Linares et al. 2011) y se pueden encontrar de manera exógena en algunos vegetales, alimentos y bebidas fermentadas, tales como quesos curados, pescados, embutidos, sidra, cervezas y vinos, produciéndose principalmente por la descarboxilación de los correspondientes aminoácidos precursores mediante microorganismos implicados en el proceso de fabricación (fermentación) (Zee et al. 1983; Izquierdo-Pulido et al. 1989; Silla Santos 1996; Moret et al. 2005; Restuccia et al. 2011).

(a)<smiles>NCCc1ccc(O)cc1</smiles>

(b)

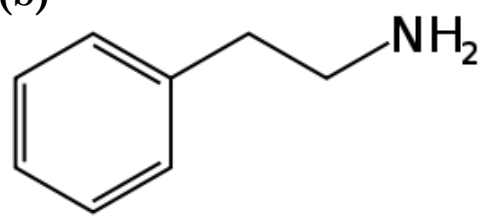

(c)<smiles>NCCCCN</smiles>

(d)<smiles>NCCCCCN</smiles>

(e)

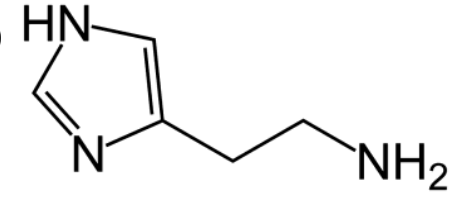

Figura 3. Principales aminas biógenas en el vino y alimentos

(a) Tiramina, (b) Feniletilamina, (c) Putrescina, (d) Cadaverina, (e) Histamina

Las investigaciones de la histamina, comenzaron desde los inicios del siglo $\mathrm{XX}$, cuando fue descubierta y denominada como $\beta$-Iminazolil etilamina por Dale \& Laidlaw (1910), dicha amina se produce cuando se desprende una molécula de dióxido de carbono de la histidina.

La histamina es un importante mediador en numerosas reacciones biológicas-fisiológicas, entre las cuales se encuentran la secreción de ácido en el estómago, actúa como neurotransmisor en el sistema nervioso y como mediador en los fenómenos alérgicos debido a su unión con receptores específicos (H1R, H2R, H3R y H4R) (Álvarez 1992; Jørgensen et al. 2007; Maintz \& Novak 2007; Díaz 2012). 
Por otra parte, la descarboxilación de la tirosina por ciertas bacterias ácido lácticas (BAL) mediante la enzima tirosina descarboxilasa (TDC) conduce a la presencia indeseable de tiramina en alimentos fermentados (Fernández et al. 2007). La mayoría de las intoxicaciones alimentarias se relacionan fundamentalmente con la histamina y la tiramina causando algunos síntomas como alteraciones en la presión arterial, dolor de cabeza, urticaria, náuseas y vómitos (Marquardt \& Werringloer 1965; Shalaby 1997; Landete 2005; Maintz \& Novak 2007; Garcia-Moruno \& Muñoz 2012), sin embargo un aspecto importante que también se ha estudiado es la influencia organoléptica de otras aminas, como la putrescina y cadaverina (Palacios et al. 2005).

\subsubsection{Importancia de las aminas biógenas}

Se ha dicho que las $\mathrm{AB}$ exógenas son encontradas principalmente en pescados, mariscos, vegetales fermentados, quesos y embutidos madurados, cervezas y vinos, generalmente indicando el deterioro del producto.

En los vinos, las $\mathrm{AB}$ no volátiles (histamina y tiramina, principalmente) se producen como sales sin aroma, sin embargo debido al $\mathrm{pH}$ que prevalece en la boca (6-7), son parcialmente liberadas y su sabor puede hacerse evidente (Lehtonen 1996). Por otra parte, las aminas volátiles (cadaverina y putrescina) que se encuentren en exceso modifican el equilibrio aromático y gustativo del vino, incluyendo la fase retronasal del mismo (Palacios et al. 2005).

Además de su papel biológico como fuentes de nitrógeno y precursores para la síntesis de hormonas, alcaloides, ácidos nucleicos y proteínas, las aminas también son importantes componentes de aroma de alimentos y precursores potenciales para la formación de compuestos N-nitroso cancerígenos (Silla Santos 1996; González-Marco \& Ancín-Azpilicueta 2006).

Las AB son esenciales, a bajas concentraciones, para las funciones normales metabólicas y fisiológicas en animales, plantas y microorganismos. Sin embargo, aminas como histamina o tiramina pueden tener efectos adversos en concentraciones altas, produciendo dolores de cabeza, dificultad respiratoria, náuseas, palpitaciones cardiacas, híper-hipotensión y varios trastornos alérgicos que presentan un riesgo para la salud principalmente para personas sensibles (Bauzaa et al. 1995; Silla Santos 1996; Moreno-Arribas \& Polo 2009), además la presencia de etanol en el cuerpo promueve y aumenta su toxicidad ya que se ha demostrado que existe una amplia relación entre la ingestión de bebidas alcohólicas y un aumento de la concentración de histamina en el plasma, conjuntamente con la presencia de estornudos, enrojecimiento, dolor de cabeza, ataques de asma, entre otras reacciones, esto debido a la capacidad de 
inhibición que tiene el etanol sobre las amina oxidasas (Marquardt \& Werringloer 1965; Soufleros et al. 1998; Maintz \& Novak 2007).

Los estudios publicados sobre los efectos toxicológicos en humanos son contradictorios, algunos autores consideran que la presencia de $\mathrm{AB}$ en el vino podría ser un importante problema de seguridad alimentaria debido a una cierta implicación de estos compuestos en los casos de intolerancia, otros mencionan que no hay correlación entre la concentración de $\mathrm{AB}$ en muestras de vino y la aparición de los síntomas. Por ejemplo, Kanny et al. (2001) menciona que el vino tinto no contiene suficiente cantidad de compuestos que producen dolor de cabeza (histamina y tiramina), sin embargo Silla Santos (1996), asegura que cuando las rutas catabólicas normales de aminas se inhiben o una gran cantidad de $\mathrm{AB}$ en alimentos se ingieren, pueden ocurrir varios cambios fisiológicos.

La histamina y otras $\mathrm{AB}$ están presentes en muchos alimentos y su presencia aumenta con la maduración. La formación de $\mathrm{AB}$ requiere disponibilidad de aminoácidos libres, la presencia de enzimas descarboxilasas en microorganismos y condiciones que permitan el crecimiento bacteriano y la actividad de dichos catalizadores. Los aminoácidos libres se producen como tal en los alimentos o pueden ser liberados por proteólisis durante el procesamiento y/o el almacenamiento. Las altas concentraciones de histamina se encuentran principalmente en productos de fermentación, tales como queso añejo, chucrut, vino y carne procesada o en mal estado.

La histamina juega un papel especial como indicador sanitario en la familia de las $\mathrm{AB}$, algunos autores han sugerido su determinación como método de evaluación de la frescura y calidad de los alimentos (Battaglia \& Fröhlich 1978; Lehtonen 1996).

\subsubsection{Funciones fisiológicas de la histamina y su intolerancia}

En humanos, la histamina es sintetizada en el aparato de Golgi por Lhistidina descarboxilasa y la acción de la vitamina B-6 (Fosfato piridoxal) como cofactor. La histamina es un importante mediador en numerosas reacciones biológicas; regula la secreción de ácido en el estómago, actúa como neurotransmisor en el sistema nervioso y actúa como mediador en los fenómenos alérgicos. Los efectos que se llevan a cabo son por la unión de sus 4 receptores sobre las células de diversos tejidos (H1R, H2R, H3R, y H4R), esto puede provocar vasodilatación, incrementar la permeabilidad muscular y la secreción de la mucosa, taquicardia, alteraciones en la presión de la sangre y arritmia (Maintz \& Novak 2007; Jones \& Kearns 2011). 
La histamina es capaz de modular la actividad celular en muchos tejidos, incluyendo la dermis, intestino delgado, estómago, pulmón y cerebro (Jones \& Kearns 2011). Sin embargo, una vez que se libera la histamina, el fin de su acción en varias áreas del cuerpo se debe a la biotransformación y a la saturación de los receptores. La histamina se metaboliza rápidamente (vida media de $\approx 1 \mathrm{~min}$ ), por dos principales enzimas, la histamina- $\mathrm{N}$-metiltransferasa (HNMT) y la DAO, en función de su ubicación (Figura 4):

- Desaminación oxidativa catalizada por la DAO (Extracelular Membrana plasmática)

- Metilación en el anillo catalizada por la HNMT (Intracelular - Citosol)

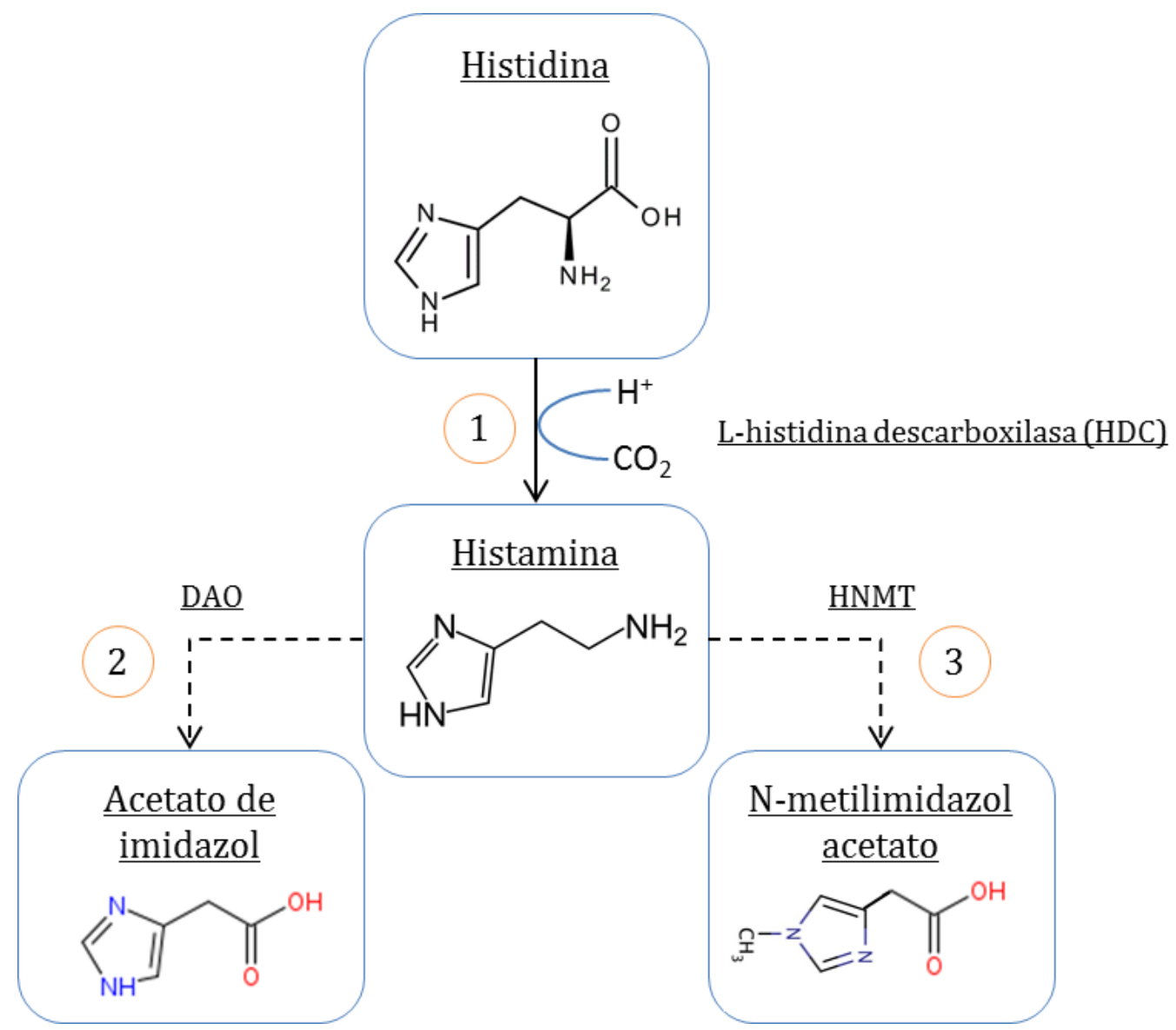

Figura 4. Resumen del metabolismo de la histamina

La histamina se sintetiza por descarboxilación de la histidina por HDC (1). Se metaboliza mediante la desaminación oxidativa extracelular por DAO (2) o la metilación intracelular por HNMT (3). Modificado de Maintz \& Novak (2007)

La afinidad que tiene HNMT hacia la histamina es ligeramente mayor que la de $\mathrm{DAO}$, con una $k_{M}$ : 6-13 $\mu \mathrm{mol} / \mathrm{L}$ y $20 \mu \mathrm{mol} / \mathrm{L}$, respectivamente. Sin embargo debido a la ubicación de cada una, no existe competencia por sustrato. 
En mamíferos, la expresión de la DAO es restringida a tejidos específicos, las actividades más altas mostradas se encuentran en el intestino delgado, colon, plasma y riñón. La HNMT es ampliamente expresada en los tejidos humanos, sin embargo la mayor actividad encontrada está en el hígado y riñón, seguido del bazo, colon, próstata, ovarios, bronquios y tráquea.

La principal causa de intolerancia a la histamina se debe a un daño genético que afecta la actividad enzimática de la DAO y la HNMT, lo cual provoca que las personas intolerantes sufran algunas patologías en intervalos de concentración que para otras sean normales. También algunos daños gastrointestinales pueden causar un decremento en la producción de la DAO, así como la excesiva cantidad de aminas, alcohol y algunas drogas ingeridas, que pueden tener un efecto inhibitorio de su actividad. Afortunadamente, estos procesos pueden ser reversibles si se eliminan o reducen las causas.

Las concentraciones de histamina consideradas normales en el plasma están entre 0.3 y $1.0 \mathrm{ng} / \mathrm{mL}$, al exceder la tolerancia individual puede llegar a causar diversos síntomas (Tabla 1).

Tabla 1. Efectos clínicos de acuerdo a la concentración de histamina en plasma

\begin{tabular}{c|l}
\hline Histamina (ng/mL) & \multicolumn{1}{c}{ Efecto Clínico } \\
\hline $0.3-1$ & Ninguno (Concentración en plasma necesaria) \\
\hline $1-2$ & $\begin{array}{l}\text { Aumento en la secreción de ácido gástrico } \\
\text { Aumento en el ritmo cardiaco }\end{array}$ \\
\hline $3-5$ & $\begin{array}{l}\text { Taquicardia, dolor de cabeza, urticaria, enrojecimiento, } \\
\text { prurito }\end{array}$ \\
\hline $6-8$ & Disminución de la presión arterial \\
\hline $7-12$ & Broncoespasmo \\
$\approx 100$ & Paro cardiaco \\
\hline
\end{tabular}

Fuente: Maintz \& Novak (2007)

Los síntomas típicos de la intolerancia a la histamina, ya sea por causas exógenas o genéticas, incluyen trastornos gastrointestinales, estornudos, rinorrea, congestión nasal, dolor de cabeza, arritmias, urticaria, prurito, enrojecimiento y asma.

El dolor de cabeza inducido por histamina es causado principalmente por monóxido de nitrógeno $(\mathrm{NO})$, la histamina al estimular el receptor $\mathrm{H} 1 \mathrm{R}$ que se encuentra en las arterias intracraneales, activa la NO-sintasa que produce NO, provocando su acumulación y dilatación de los vasos sanguíneos (Thomsen \& Olesen 2001; Jørgensen et al. 2007; Maintz \& Novak 2007; Alstadhaug 2014). 
Enfermedades gastrointestinales, como dolor de estómago, cólicos, flatulencia y diarrea son unos de los síntomas principales de la intolerancia a la histamina ya que se ha relacionado con varias enfermedades inflamatorias y neoplásicas (Maintz \& Novak 2007).

Durante o inmediatamente después de la ingestión de alimentos ricos en histamina, la obstrucción nasal o rinorrea puede ocurrir en pacientes con intolerancia a la histamina, en casos extremos, los ataques de asma también pueden ocurrir (Maintz \& Novak 2007).

\subsubsection{Funciones fisiológicas de otras aminas biógenas}

La tiramina es considerada una molécula vasoactiva ya que tiene efectos vasoconstrictores sobre los vasos cerebrales y sistémicos, tiene la función de liberar noradrenalina del sistema nervioso simpático, lo que en exceso da lugar a un incremento en la presión sanguínea, dolor de cabeza, hipertensión y dilatación de pupilas, también provoca lagrimeo, salivación e incremento de la respiración (Shalaby 1997; Landete, Ferrer, Polo, et al. 2005).

La putrescina y cadaverina son responsables de regular la función de los ácidos nucleicos y la síntesis de proteínas, sin embargo una incontrolada ingesta de estas aminas puede provocar hipotensión, disnea y paresia de extremidades, además de potenciar los efectos negativos causados por otras aminas (Shalaby 1997).

\subsubsection{Antecedentes de aminas biógenas en alimentos y bebidas}

Se ha demostrado que el origen de la histamina y tiramina es consecuencia de la actividad microbiana descarboxilasa sobre sus aminoácidos precursores provenientes de los alimentos y bebidas fermentados, es decir, se puede esperar su presencia en casi todos los alimentos que contienen proteínas o aminoácidos libres y están sujetos a las condiciones que permitan la actividad microbiana.

La mayoría de los alimentos fermentados, tales como queso, embutidos fermentados y cervezas, que son consumidos con más frecuencia que los vinos, tienen un contenido de AB superior (Izquierdo-Pulido et al. 2000; Fernández et al. 2007). Sin embargo, la presencia de alcohol en el vino puede aumentar la actividad de las aminas ya que inhibe las enzimas que metabolizan las $\mathrm{AB}$ en el cuerpo (N-metil-transferasas y amino oxidasas) (ten Brink et al. 1990).

En 1989, Izquierdo-Pulido et al., determinaron el contenido de histamina y tiramina en 65 cervezas europeas que se consumen en España, ambas aminas 
fueron detectadas en todas las muestras, el $94 \%$ de las cervezas tuvo menos de $2 \mathrm{mg} / \mathrm{L}$ de histamina, sin embargo, sólo el $8 \%$ mostraron valores inferiores a dicho valor de tiramina, también observaron que el $10 \%$ tuvo más de $10 \mathrm{mg} / \mathrm{L}$ de tiramina. Los contenidos de ambas aminas fueron mayores en cervezas con valores altos de acidez total y de $\mathrm{pH}$. También observaron que las cervezas con menos tiempo de fermentación tenían el mayor contenido de histamina.

En un estudio posterior sobre cerveza, se observó una clara formación de tiramina durante la fermentación (de 2.5 a $40.5 \mathrm{mg} / \mathrm{L}$ ), sin embargo la formación de histamina fue insignificante en este mismo periodo (IzquierdoPulido et al. 1991).

Kalač et al. (2002) determinaron algunas $\mathrm{AB}$ en puré de espinacas congeladas, salsa de tomate, pasta de tomate concentrado en lata y chícharo congelado; se observó putrescina y espermidina en la mayoría de las muestras, las concentraciones de histamina y espermina fueron bajos, y los de cadaverina y triptamina bajos o medios. Los niveles máximos encontrados en la salsa de tomate fueron 33.6 y $52.5 \mathrm{mg} / \mathrm{kg}$ de tiramina y putrescina, respectivamente, $\mathrm{y}$ $46.6 \mathrm{mg} / \mathrm{kg}$ de espermidina en chícharo. Según los autores, con el estudio determinan la presencia de $\mathrm{AB}$ en dichos vegetales, sin embargo concluyen que la concentración no es de riesgo para consumidores sanos según los niveles aceptables propuestos por Nout (1994), que van desde 100 hasta 200 ppm.

Otro estudio relacionado a la presencia de aminas en vegetales fue el realizado por Moret et al. (2005), quienes analizaron AB en algunos vegetales frescos y en conserva. Los autores encontraron que, a excepción de la muestra de chucrut, la putrescina y espermidina fueron las aminas más representativas con intervalos de 0.2-0.5 mg/100 g y 0.4-4.5 mg/100 g de peso fresco, respectivamente. En contraste, el nivel de tiramina fue de $4.9 \mathrm{mg} / 100 \mathrm{~g}$ de chucrut en lata, mientras que la muestra de espinaca mostró el más alto contenido de histamina $(2.0 \mathrm{mg} / 100 \mathrm{~g})$.

Estudios como el de Novella-Rodríguez et al. (2002) y el de Restuccia et al. (2011), demostraron la presencia y generación de AB durante la maduración de quesos. Por otra parte, en quesos Pecorino, se detectó el contenido de AB, además de las bacterias que mostraron actividad descarboxilante. En la mayoría de las muestras de dicha variedad de queso, el contenido de $\mathrm{AB}$ resultó elevado, con una prevalencia de histamina y tiramina (Schirone et al. 2013).

Ensayos realizados por Barba et al. (2012) tuvieron como objetivo evaluar el contenido de histamina y la calidad microbiológica de pescados de las especies Sierra del Pacífico, Lisa y Dorado, comercializados en el puerto de Mazatlán, 
Sinaloa, México. Los autores determinaron la calidad microbiológica determinando la presencia de bacterias con actividad descarboxilasa sobre la histidina. La histamina se cuantificó por fluorometría y espectrofotometría, dando una concentración máxima de 10.6, 10.7 y $13.9 \mathrm{mg} / \mathrm{kg}$ para Sierra, Lisa y Dorado, respectivamente. La prueba que realizaron para comprobar la existencia de bacterias con actividad descarboxilasa sobre la histidina fue positiva en todos los casos. Ellos concluyeron que estas tres especies de pescado analizadas no representan algún tipo de riesgo para la salud de un consumidor sano, sin embargo recomiendan implementar buenas prácticas de higiene y sanidad para reforzar la condición inocua de este tipo de alimento.

Un estudio más reciente realizado por Buňka et al. (2013) también evaluó el contenido de $8 \mathrm{AB}$ (histamina, tiramina, feniletilamina, triptamina, putrescina, cadaverina, espermidina y espermina) en 112 muestras de pescado (ofrecidos en restaurantes de República Checa). Encontraron que en 6 muestras de pescado, la concentración de histamina fue superior a los límites indicados en la Comisión de Regulación de dicha región (más de $200 \mathrm{mg} / \mathrm{kg}$ ). La alta concentración sugiere la necesidad de mantener las condiciones de conservación (refrigeración y/o congelación en la cadena de frio) hasta la distribución de productos a los consumidores.

\subsubsection{Antecedentes de histamina y otras aminas biógenas en vino}

Según Lehtonen (1996) se han encontrado más de 20 AB diferentes en el vino, y de acuerdo a lo reportado por diversos autores, la putrescina, histamina y tiramina son las predominantes, siendo putrescina la más abundante e histamina la más peligrosa debido a su actividad biológica (Buteau et al. 1984; Lehtonen 1996; Glória et al. 1998; Soufleros et al. 1998; Vázquez Lasa et al. 1998; Marcobal et al. 2005; Proestos et al. 2008; Henríquez-Aedo et al. 2012).

Debido a los riesgos fisiológicos que puede causar la ingesta excesiva de histamina, ésta $\mathrm{AB}$ ha sido estudiada extensamente durante varios años, siendo encontrada por primera vez en el vino por Tarantola (1954), quien impulsó a desarrollar investigaciones sobre la formación de $\mathrm{AB}$ en vinos.

Uno de los primeros trabajos fue el realizado por Marquardt \& Werringloer (1965), quienes encontraron hasta $22 \mathrm{mg} / \mathrm{L}$ de histamina en vino, al analizar jugo de uva sin fermentar, no encontraron presencia de esta amina.

Las investigaciones que reportan la presencia de histamina se muestran en la Tabla 2, donde se resumen los primeros resultados de las determinaciones realizadas principalmente en vinos Europeos, así como el método utilizado. 
Tabla 2. Primeros resultados sobre análisis de histamina

\begin{tabular}{|c|c|c|c|c|c|}
\hline \multirow{2}{*}{ Año } & \multicolumn{2}{|c|}{ Histamina [mg/L] } & \multirow{2}{*}{$\begin{array}{l}\text { Número } \\
\text { de } \\
\text { muestras }\end{array}$} & \multirow{2}{*}{ Materia Prima } & \multirow[b]{2}{*}{ Método } \\
\hline & Rango & Promedio & & & \\
\hline$(1965)$ & $0-22$ & --- & 100 & $\begin{array}{l}\text { Vinos Europeos, Norafricanos y } \\
\text { Chilenos }\end{array}$ & Cromatografía \\
\hline (1966) & --- & 1.7 & 13 & Vinos Europeos tintos y blancos & Cromatografía de Capa Fina \\
\hline$(1967)$ & $0-10$ & 0.85 & 33 & Vinos Alemanes & Fisicoquímico \\
\hline (1968) & $0.05-9.3$ & 1.8 & 12 & Vinos Franceses & Fluorescencia \\
\hline (1968) & $0.6-20$ & --- & 7 & Vinos Europeos & Fisicoquímico \\
\hline$(1969)$ & $7-8$ & --- & 2 & Vinos Suizos tintos y blancos & Electroforesis en gel \\
\hline$(1969)$ & $0.1-30$ & 5.4 & 60 & Vinos Franceses & Fisicoquímico \\
\hline
\end{tabular}

La concentración de aminas reportada a finales de los años 90 estaba en un intervalo de trazas hasta más de $130 \mathrm{mg} / \mathrm{L}$ (Soufleros et al. 1998).

Debido a las posibles consecuencias fisiológicas al consumidor, desde hace más de 50 años se han realizado diferentes estudios sobre la presencia de histamina y otras $\mathrm{AB}$ en vinos de varias regiones del mundo, así como analizado los diversos factores que intervienen en su concentración, principalmente países de Europa tales como España (Vidal-Carou et al. 1990; Iñiguez Crespo \& Vázquez Lasa 1994; Vázquez Lasa et al. 1998; MorenoArribas et al. 2003; Landete, Ferrer, Polo, et al. 2005; Marcobal et al. 2005; Martín-Álvarez et al. 2005; Moreno-Arribas \& Polo 2008; Izquierdo Cañas et al. 2009; García-Ruiz et al. 2011), Francia (Zee et al. 1983; Lucas et al. 2005; Nannelli et al. 2008; Romano et al. 2012), Portugal (Herbert et al. 2005; Leitão et al. 2005), Grecia (Pramateftaki et al. 2006; Soufleros et al. 2007) e Italia (Martuscelli et al. 2013).

Por otra parte, han sido pocos los estudios publicados sobre vinos de origen Americano; Ough (1971), presentó el primer ensayo en vinos de California, EE.UU., posteriormente Glória et al. (1998), evaluaron el contenido de AB en muestras de Pinot Noir y Cabernet Sauvignon producidos en Oregon, EE.UU., Henríquez-Aedo et al. (2012) determinó un perfil de AB en vinos chilenos, sin embargo aún no existen reportes en los que se hayan evaluado vinos de origen mexicano. 


\subsubsection{Limitaciones de histamina en el vino}

Quevauviller \& Mazière (1969) reportaron que con sólo $8 \mathrm{mg} / \mathrm{L}$ de histamina era posible inducir dolores de cabeza cuando se ingerían grandes cantidades de vino, algo similar a lo reportado por Battaglia \& Fröhlich (1978), quienes señalan que a una concentración de $5 \mathrm{mg} / \mathrm{L}$ de histamina puede provocar dolores de cabeza después del consumo de $0.5 \mathrm{~L}$ de vino. Sin embargo, actualmente existen algunos trabajos que toman como referencia a la Autoridad Europea de Seguridad Alimentaria (EFSA, por sus siglas en inglés, European Food Safety Authority) (EFSA 2011), quienes mencionan que una cantidad por debajo de $50 \mathrm{mg}$ de histamina consumida es tolerante para personas sanas (Arrieta \& Prats-Moya 2012; Coloretti et al. 2013).

Debido a los riesgos que puede causar la histamina ingerida a causa del consumo de vino, Suiza ha establecido un nivel máximo para la histamina de 10 $\mathrm{mg} / \mathrm{L}$, habiendo también recomendaciones en Alemania $(2 \mathrm{mg} / \mathrm{L})$, Holanda (3.5 $\mathrm{mg} / \mathrm{L})$, Bélgica (5-6 mg/L), Finlandia $(5 \mathrm{mg} / \mathrm{L})$ y Francia $(8 \mathrm{mg} / \mathrm{L})$ (Lehtonen 1996; Martín-Álvarez et al. 2005).

\subsubsection{Factores enológicos que afectan la presencia de aminas biógenas}

Diversos autores que han evaluado $\mathrm{AB}$ en diferentes tipos de vinos (tintos, blancos y rosados) han coincidido que la mayor cantidad de aminas se encuentra presente en los vinos tintos (Zee et al. 1983; Lehtonen 1996; Vázquez Lasa et al. 1998; Leitão et al. 2005; Bartowsky \& Stockley 2010; Martuscelli et al. 2013).

El hecho de que este tipo de vino contenga más histamina que los demás se debe a que la vinificación en tinto se lleva a cabo usualmente la maceración del hollejo junto con el jugo de uva, aumentando la cantidad de aminoácidos (precursores) disponibles en el mosto (Quevauviller \& Mazière 1969; Cilliers \& Van Wyk 1985; Martuscelli et al. 2013).

Por otra parte, se ha encontrado que no existe producción significante de $\mathrm{AB}$ durante la fermentación alcohólica, por lo que las levaduras no parecen ser las responsables de su síntesis (Marquardt \& Werringloer 1965; Buteau et al. 1984; Vidal-Carou et al. 1990; Marcobal, de las Rivas, et al. 2006).

Soufleros et al. (1998), encontraron que un gran número de aminas pueden ser formadas a partir de sus aminoácidos precursores, principalmente durante y después de la fermentación maloláctica, lo que concuerda con otros estudios (Herbert et al. 2005; Pramateftaki et al. 2006; Hernández-Orte et al. 2008). 
Según Soufleros et al. (2007), cantidades altas de AB coincide con niveles altos de ácido láctico, por lo que la formación de aminas está relacionada con la microflora de la fermentación maloláctica (BAL), lo cual concuerda con diversos autores (Lonvaud-Funel \& Joyeux, 1994; Coton et al. 1998; MorenoArribas et al. 2000; Guerrini et al. 2002; Landete, Ferrer et al. 2005a).

Además de los aminoácidos como precursores y las bacterias capaces de producir aminas biógenas, otro factor importante en la síntesis de $\mathrm{AB}$ son los parámetros enológicos (Martín-Álvarez et al. 2005).

Se ha encontrado que la adición de $\mathrm{SO}_{2}$ presenta un cierto poder inhibitorio para la producción de AB (Vidal-Carou et al. 1990), debido a que dicho compuesto, entre otras funciones, es un agente antimicrobiano que controla el desarrollo de bacterias principalmente (Blouin \& Peynaud 2003).

Algunos autores han detectado que con valores enológicos de $\mathrm{pH}$ bajos (3.0-3.4), se evita la producción de $\mathrm{AB}$, mientras que valores por encima de 3.7 propicia su formación (Cilliers \& Van Wyk 1985; Lonvaud-Funel \& Joyeux 1994; Landete, Ferrer, Polo, et al. 2005).

La región vitivinícola y el tipo de uva también son factores determinantes para la presencia de $\mathrm{AB}$, ya que el clima, ubicación (latitud y altitud) y metabolismo propio de cada variedad de uva, influye en la concentración de aminoácidos presentes en el hollejo, los cuales, como se ha mencionado, son los precursores para la síntesis de AB (Herbert et al. 2005; Leitão et al. 2005; Landete, Ferrer, Polo, et al. 2005; Marques et al. 2008).

La interacción del mosto con las lías del vino durante el almacenamiento propicia mayor formación de $\mathrm{AB}$, ya que las proteínas celulares de las levaduras se hidrolizan aumentando la cantidad de aminoácidos en el medio (Marques et al. 2008).

Se han realizado varios ensayos sobre la relación que tiene la inoculación de BAL comerciales en la vinificación y la presencia de $\mathrm{AB}$, encontrando que los cultivos comerciales minimizan la cantidad de $\mathrm{AB}$ en el vino debido a que no cuentan con la capacidad de producirlas (Marques et al. 2008; Hernández-Orte et al. 2008; Smit \& du Toit 2011).

\subsubsection{Técnicas para la detección de aminas biógenas en vinos}

Previo a los años 90, la mayoría de las determinaciones de $\mathrm{AB}$ en vinos se realizaban utilizando métodos fisicoquímicos, cromatografía en capa fina o espectrofluorométricos con los que sólo se valoraban algunas aminas de forma 
individual, además de requerir procesos de extracción elaborados (Ough 1971; Zee et al. 1981; Zee et al. 1983; Vidal-Carou et al. 1989; Vidal-Carou et al. 1991).

Sin embargo, uno de los primeros estudios que utilizó HPLC y un detector UV junto con un proceso de derivación con ortoftalaldehído (OPA), fue el realizado por Subden et al. (1979), quienes analizaron vinos canadienses, los cuales presentaron un intervalo de concentración de 0.09 a $6.11 \mathrm{mg} / \mathrm{L}$.

La Organización Internacional de la Viña y el Vino (OIV), tiene propuesto un método oficial para la determinación de $\mathrm{AB}$ en vinos, el cual se realiza mediante RP-HPLC en una columna $\mathrm{C} 18$, previa generación de derivados con OPA capaces de ser detectados por fluorescencia. La técnica fue validada de acuerdo a los resultados y reproducibilidad favorables obtenidos por varios autores (Glória et al. 1998; Herbert et al. 2005; Leitão et al. 2005; Landete, Ferrer, Polo, et al. 2005; Marcobal et al. 2005; Yildirim et al. 2007; MorenoArribas \& Polo 2008; García-Ruiz et al. 2011; Arrieta \& Prats-Moya 2012).

Sin embargo, otro agente para generar el derivado ha sido el cloruro de dansilo, con el cual los compuestos pueden ser detectados mediante fluorescencia o UV-vis (Anlı et al. 2004; Zhijun et al. 2007; Soufleros et al. 2007; Proestos et al. 2008).

Un método enzimático fue descrito por Landete et al. (2004), el cual permite la determinación directa de la concentración de histamina sobre medios de cultivo sintéticos, mosto de uva o vino (blanco, rosado o tinto). La prueba enzimática se basa en la actividad secuencial de dos enzimas: DAO, que cataliza la degradación de histamina (produciendo acetaldehído imidazol, amoniaco, y peróxido de hidrógeno), y la peroxidasa que, en presencia de peróxido de hidrógeno, produce un cambio de color. Este método se comparó frente a la técnica de RP-HPLC, mostrando una alta correlación $\left(\mathrm{R}^{2}=0.9987\right)$.

Un nuevo método analítico optimizado para la detección y cuantificación de aminas biógenas fue el propuesto por Bach et al. (2012), el cual tiene las ventajas de obtener fácilmente los derivados para la cuantificación de aminas biógenas, además de una degradación completa del reactivo de derivación en exceso durante la preparación de la muestra con el fin de preservar la columna. Los autores realizaron una adaptación del método que fue inicialmente desarrollado para el análisis de aminas biógenas, aminoácidos e iones amonio en vinos y cervezas por Gómez Alonso et al. (2007). Consiste en una separación por RP-HPLC y detección UV-vis del producto formado por derivación con etoximetilen-malonato de dietilo. El método está siendo valorado para ser un método de referencia por la OIV. 


\subsection{Bacterias ácido lácticas}

Las BAL son organismos procariotas, de morfología variada, pudiendo ser bacilos, cocos o coco-bacilares agrupándose en parejas, cadenas o tétradas, no son formadoras de endoesporas y carecen de un mecanismo de movilidad por parte de flagelos, son consideradas Gram positivas debido a que no poseen una membrana externa conformada por lipopolisacáridos y proteínas, cuentan con una capa de peptidoglicano (mureína) que corresponde cerca del 90\% de la pared celular y una membrana plasmática (Figura 5) (Schlegel 1997; Madigan et al. 2003; Suárez \& Íñigo 2004; Landete 2005).

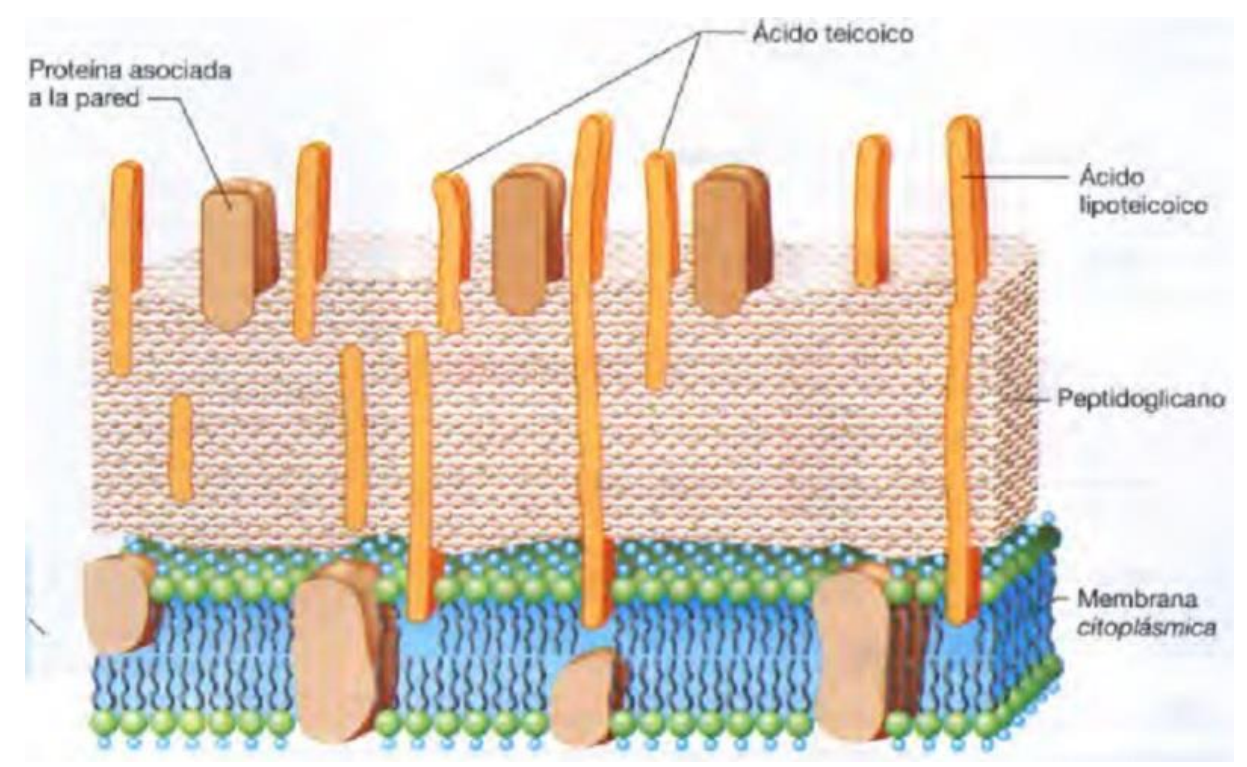

Figura 5. Estructura global de la pared celular Gram positiva

Fuente: Madigan et al. (2003)

Éste tipo de bacterias generan ácido láctico como producto de fermentación, carecen de catalasa, además tienen la capacidad de poder crecer en medios anaerobios sin ser sensibles al oxígeno, por lo que se consideran microorganismos anaerobios aerotolerantes (Blouin \& Peynaud 2003; Madigan et al. 2003; Suárez \& Íñigo 2004).

Los medios para cultivar preferentemente son complejos, contienen cantidades relativamente altas de extracto de levadura, jugo de tomate, suero e incluso sangre (Schlegel 1997; Madigan et al. 2003).

La principal clasificación de este grupo se debe a los productos de fermentación generados a partir de los azúcares, los que generan únicamente ácido láctico se denominan homofermentativos, mientras que los heterofermentativos, producen otros compuestos como etanol o dióxido de carbono. 
Con la excepción del género Bifidobacterium, el resto de bacterias ácido lácticas están filogenéticamente relacionados y son miembros de la flora nativa de la materia prima de los alimentos y de uso directo en la tecnología de los alimentos (Kandler 1983).

Los diversos géneros de bacterias ácido lácticas se pueden definir con base en su morfología celular y tipo de fermentación (Tabla 3):

Tabla 3. Diferencia de los principales géneros de bacterias ácido lácticas

\begin{tabular}{c|cl}
\hline Género & Morfología y agrupación & Fermentación \\
\hline Streptococcus & Cocos en cadenas & Homofermentativo \\
Leuconostoc & Cocos en cadenas & Heterofermentativo \\
Oenococcus & Cocos en cadenas & Heterofermentativo \\
Pediococcus & Cocos en tétradas & Homofermentativo \\
Lactobacillus & Bacilos en cadenas & Homofermentativo \\
& Bacilos en cadenas & Heterofermentativo \\
Enterococcus & Cocos en cadenas & Homofermentativo \\
\hline
\end{tabular}

Fuentes: Kandler (1983); Ough (1996); Madigan et al. (2003); König et al. (2009)

\subsubsection{Identificación de bacterias ácido lácticas}

\subsubsection{Técnicas bioquímicas}

Tinción de Gram

La tinción de Gram, en microorganismos enológicos, se usa para diferenciar las BAL (Gram positivas) de las bacterias acéticas (Gram negativas), además de poder observar su morfología, la diferencia de color presente en los diferentes grupos se basa en la estructura y composición química de las paredes celulares. Las paredes celulares de las Gram negativas, ricas en lípidos, tienen muy poca cantidad de peptidoglicano, esto permite la penetración de alcohol y la eliminación del complejo cristal violeta-Iodo, dejando la célula sin color, que se vuelve a teñir de rojo con safranina (Figura 6a). Por otro lado, las paredes celulares de las bacterias Gram positivas contienen mucho peptidoglicano y una baja concentración de lípidos, lo que hace que dicha pared y la deshidratación provocada por el alcohol no permitan la eliminación del color violeta o azul oscuro del complejo cristal violeta-Iodo (Figura 6b). 


\section{Prueba de Catalasa}

Con esta prueba se pretende distinguir entre las bacterias acéticas y las lácticas. Las bacterias acéticas tienen una reacción positiva (Figura 6c), mientras que las bacterias ácido lácticas ofrecen una respuesta negativa. La prueba de catalasa se basa en la propiedad que tienen los microorganismos aeróbicos para descomponer el peróxido de hidrógeno liberando oxígeno.

(a)

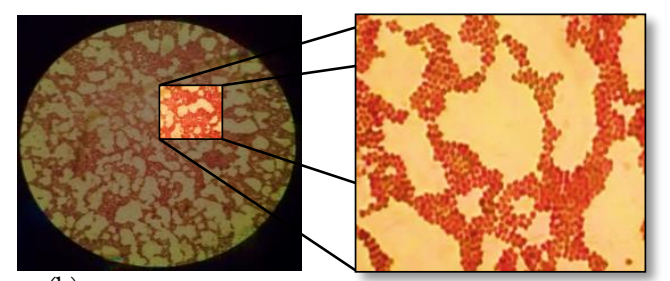

(b)
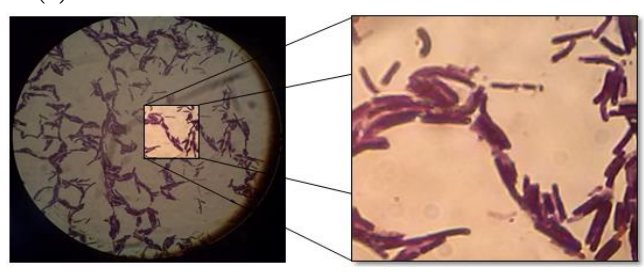

(c) $\quad 2 \mathrm{H}_{2} \mathrm{O}_{2} \rightleftharpoons 2 \mathrm{H}_{2} \mathrm{O}+\mathrm{O}_{2}$

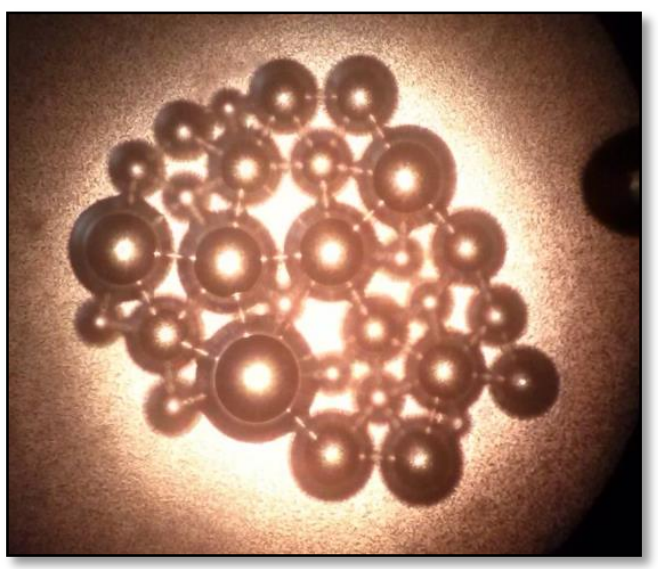

Figura 6. Pruebas bioquímicas para la detección de bacterias ácido lácticas

(a) Bacterias Gram negativas aisladas de vino con morfología de cocos

(b) Bacterias Gram positivas aisladas de vino con morfología bacilar

(c) Prueba de catalasa positiva en bacterias aisladas de vino

\subsubsection{Técnicas analíticas}

\section{MALDI-TOF/MS}

La técnica de MALDI-TOF MS, por sus siglas en inglés matrix-assisted laser desorption/ionization time-of-flight mass spectrometry, ha sido utilizada desde hace varios años para la identificación de proteínas y péptidos, sin embargo la identificación de microorganismos basada en la espectrometría de masas ha tomado mayor importancia en los últimos años como un método de rutina rápido y preciso.

El espectrómetro de masas produce, separa y detecta iones en fase gaseosa requiriendo de tres elementos principalmente: una fuente de ionización/ desorción (láser asistido por matriz), un analizador de masas (tiempo de vuelo) y un detector (Figura 7).

La técnica requiere de dos pasos previos, la obtención de una colonia aislada y la adición de una matriz que se cristaliza al contacto con el aire (generalmente una solución saturada de ácido ciano-hidroxicinámico (HCCA), acetonitrilo y 
ácido trifluoroacético) la cual tiene como propósito exponer las proteínas intercelulares mediante la ruptura celular y facilitar la desorción/ionización.

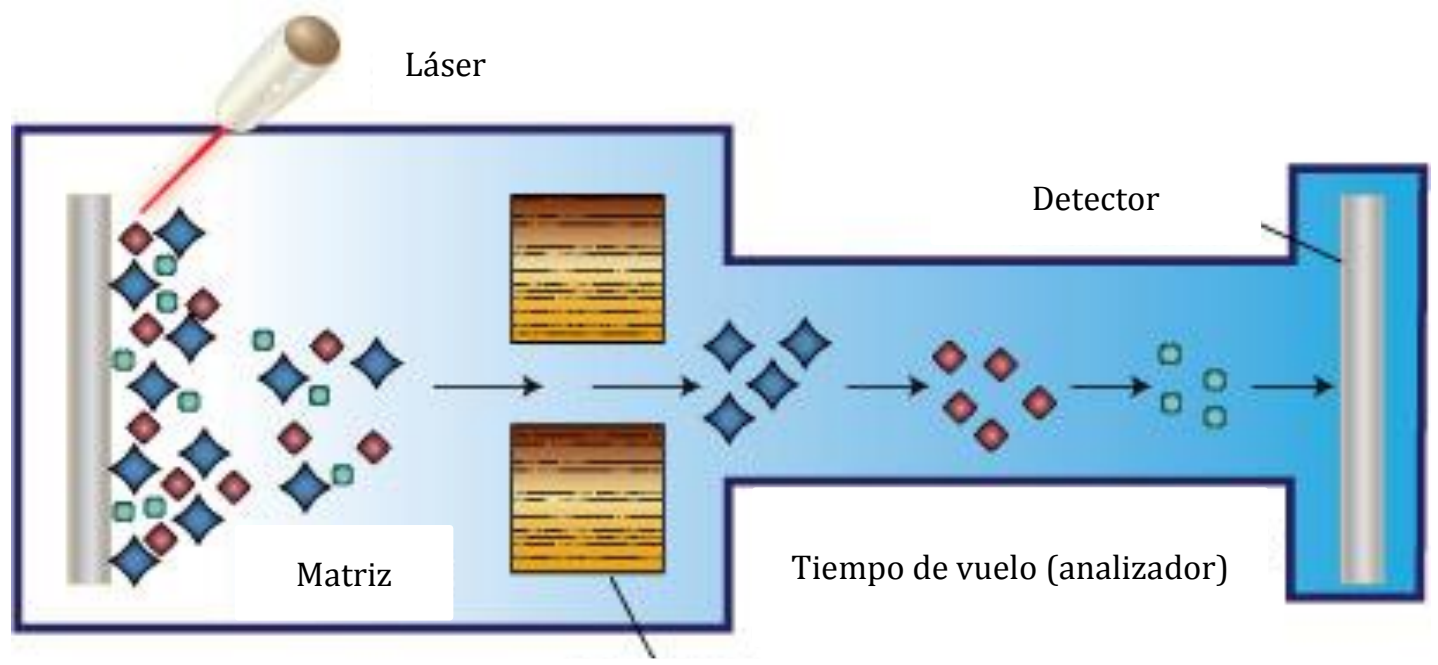

Generador de campo eléctrico

Figura 7. Componentes de un espectrómetro de masas MALDI TOF

La espectrometría de masas (MS) MALDI TOF consiste en el rompimiento de la matriz cristalizada generando una nube de iones, los cuales son atraídos por un campo eléctrico y viajan por una estructura delimitada (analizador) separándose según su masa en relación a su carga $(\mathrm{m} / \mathrm{z})$, lo que permite determinar el periodo de tiempo que tarda cada ion en llegar al detector, denominado tiempo de vuelo (TOF). Al atravesar la zona de vuelo, los iones son captados por el detector, el cual registra la información obteniendo un espectro de masas, dado que un microorganismo analizado en el MALDI-TOF MS entrega siempre el mismo espectro de masas, se han diseñado archivos con los espectros de la fragmentación de péptidos y proteínas que presentan los distintos microorganismos para una misma emisión del láser y una misma distancia de migración.

La identificación se realiza a través de la comparación del resultado de una bacteria con todos los espectros de masas que contiene la base de datos MALDI Biotyper (Bruker Daltonik, Alemania), el cual arroja un puntaje que representa su correlación, la confiabilidad de dicho valor para la identificación de microorganismos se determina de acuerdo a lo establecido por el fabricante (Bruker Daltonik 2011), estipulando que un puntaje mayor a 2.000 indica una identificación altamente confiable a nivel género y especie (color verde), mientras que puntajes menores representan una probable o nula identificación, tal y como se muestra en la Tabla 4. 
Tabla 4. Significado de los valores de puntuación MALDI Biotyper

\begin{tabular}{cccc}
\hline \multicolumn{1}{c}{ Intervalo } & Descripción & Símbolos & Color \\
\hline $\mathbf{2 . 3 0 0 - 3 . 0 0 0}$ & Identificación altamente probable a nivel especie & $(+++)$ & Verde \\
\hline $\mathbf{2 . 0 0 0 - 2 . 2 9 9}$ & Identificación segura de género, probable a nivel especie & $(++)$ & Verde \\
\hline $\mathbf{1 . 7 0 0 - 1 . 9 9 9}$ & Identificación altamente probable a nivel género & $(+)$ & Amarillo \\
\hline $\mathbf{0 . 0 0 0 - 1 . 6 9 9}$ & Ninguna identificación segura & $(-)$ & Rojo \\
\hline
\end{tabular}

Fuente: Bruker Daltonik (2011)

El MALDI Biotyper (Bruker Daltonik, Alemania) identifica microorganismos usando MALDI-TOF/MS para obtener una huella molecular única de cada organismo midiendo las proteínas más abundantes. Los patrones característicos de estas proteínas se utilizan para determinar, de forma fiable y precisa, la identidad de un microorganismo hasta el nivel de especie.

La base de datos almacena espectros principales (MSP), los cuales se basan en múltiples mediciones de una cepa definida, los espectros desconocidos se comparan con la biblioteca MSP basándose en un análisis estadístico multivariable; incluyendo posiciones de los picos, intensidades y frecuencias que garantiza los más altos niveles de precisión y reproducibilidad en toda la gama completa de microorganismos. La biblioteca está constantemente en mantenimiento y actualizada con contribuciones de muchos colaboradores de todo el mundo (Bruker Daltonik 2011).

Los datos de la muestra pueden ser analizados y comparados contra diferentes cepas de referencia. En la Figura 8 se ejemplifica la comparación de los espectros, donde el espectro de la muestra se observa sobre el eje, mientras que los datos de referencia por debajo en azul. Los emparejamientos perfectos entre los datos de la muestra y el patrón de referencia se indican en verde, por el contrario las diferencias entre datos se resaltan en rojo. Los picos azul claro se encuentran en la referencia, pero no la muestra. A partir de éste análisis se determina una puntuación que engloba la similitud de todo el espectro sobre las posiciones de los picos, sus intensidades y frecuencias.

Existen varios trabajos recientes que reportan el uso de dicha técnica de manera satisfactoria (Haag et al. 1998; Demirev et al. 1999; Lay 2002; Hsieh et al. 2008; Sauer et al. 2008; Ho \& Reddy 2010; Sauer \& Kliem 2010; García et al. 2012; Jordana-Lluch et al. 2012; Legarraga et al. 2013) validando las ventajas siguientes: 
- Los tiempos cortos de análisis comparados con otras técnicas

- Permite analizar de 96 a 384 muestras en una misma corrida

- Alta precisión

- Técnica económica de acuerdo a la relación costo/tiempo

Sin embrago, se debe tomar en cuenta que existen microorganismos bastante similares en cuanto a su composición proteínica lo que podría llegar a dificultar el análisis además de que se requiere una concentración mínima de $10^{5}-10^{6}$ células (Jordana-Lluch et al. 2012).

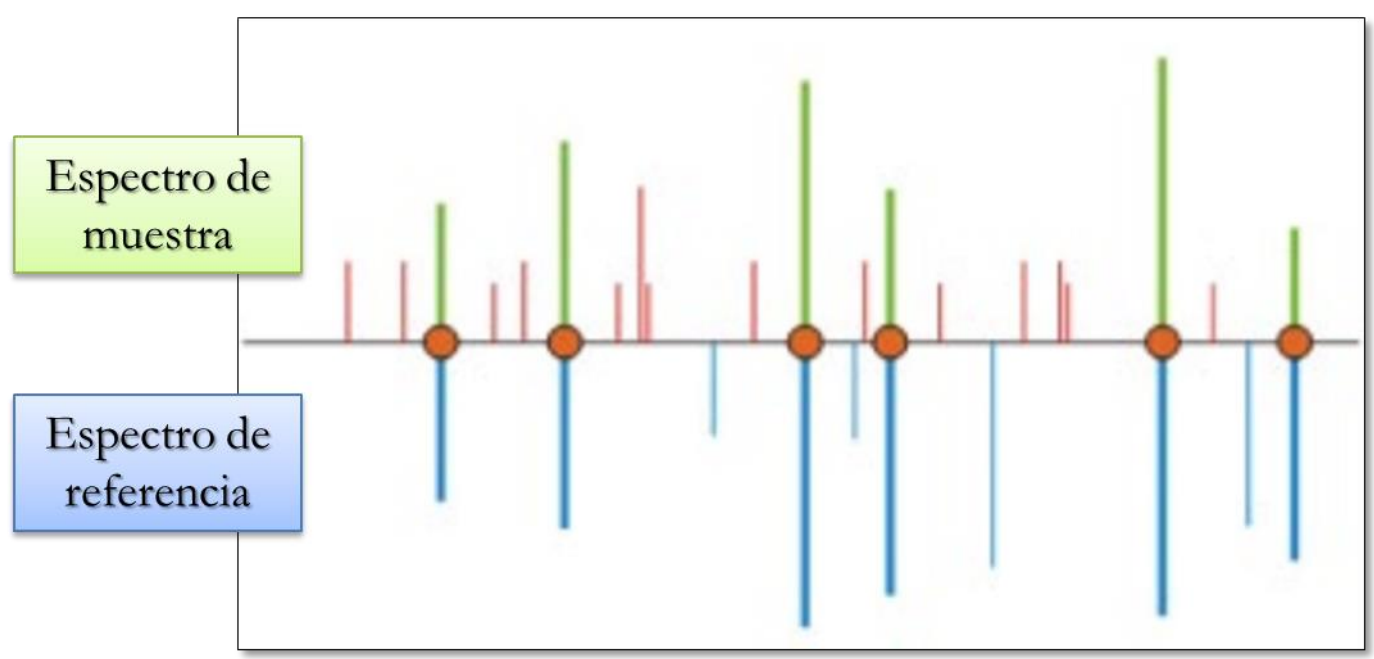

Figura 8. Análisis de espectros de masas (MALDI-TOF/MS)

Modificado de Bruker Daltonik (2011)

\subsubsection{Importancia de bacterias ácido lácticas en la enología}

Los mostos y vinos son medios muy selectivos, que pueden apoyar el crecimiento de sólo unas pocas especies de bacterias del ácido láctico. Cuatro géneros son los más representativos: Lactobacillus, Pediococcus, Leuconostoc y Oenococcus (Ough 1996; Moreno-Arribas et al. 2003).

Las BAL se encuentran ya presentes en la uva en una concentración cercana a 100 células/g, inferior a la de bacterias acéticas y levaduras (Peynaud 1977; Lafon Lafourcade 1983), a lo largo de la fermentación alcohólica la concentración de bacterias disminuye ya que compite con otro tipo de microorganismos como las levaduras, además son más sensibles a la presencia del $\mathrm{SO}_{2}$ adicionado al mosto y al etanol producido en la fermentación alcohólica. Terminada ésta, el número de BAL puede aumentar hasta $10^{7}-10^{8}$ $\mathrm{ufc} / \mathrm{mL}$ favoreciendo una segunda fermentación (Figura 9). 


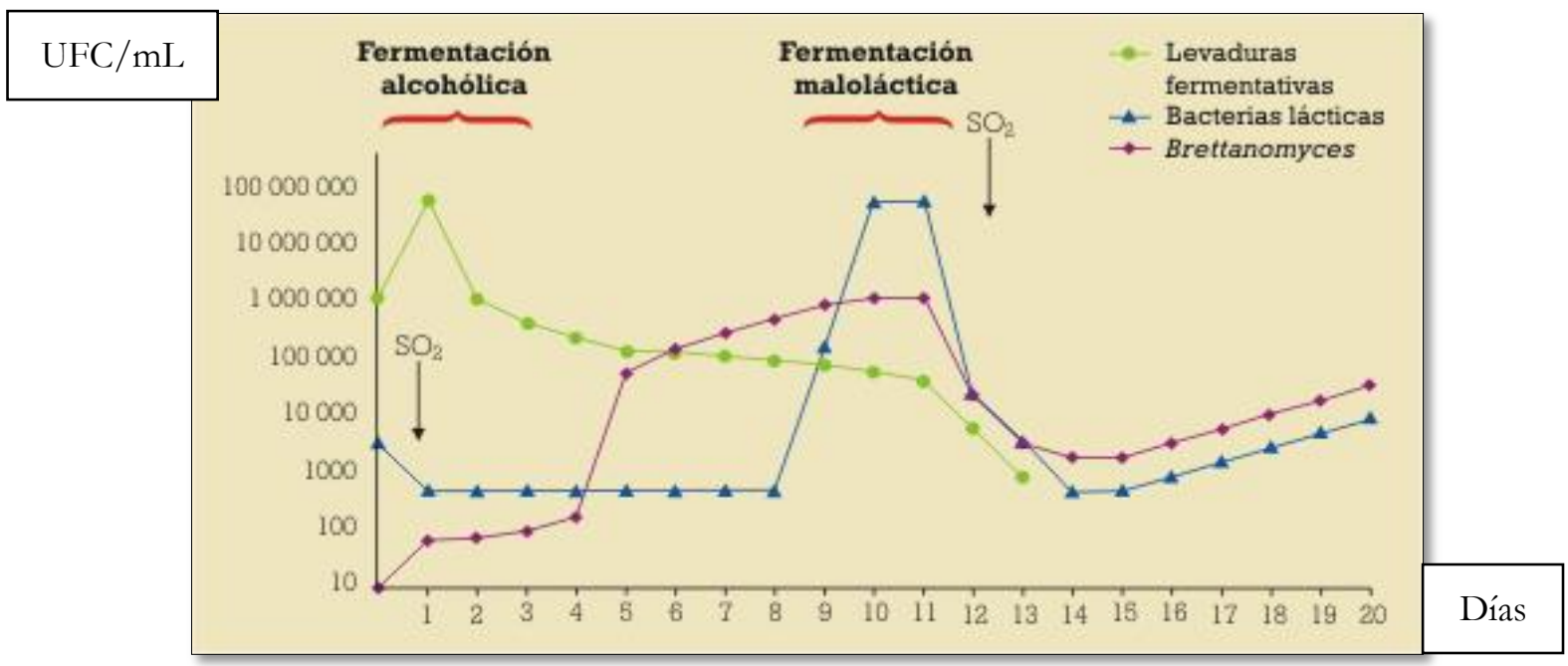

Figura 9. Cinética de levaduras y bacterias ácido lácticas durante la vinificación Fuente: López (2007)

El ácido málico es uno de los ácidos predominantes en la uva y su concentración se ve afectada por la variedad, tipo de suelo, características climáticas y prácticas culturales de la vid. En general, el mosto de las uvas contiene una cantidad de ácido málico entre 1 y $8 \mathrm{~g} / \mathrm{L}$, dándole un sabor muy ácido, por lo que se requiere disminuirlo, la función principal de las BAL en el proceso de vinificación es transformar el ácido málico del mosto en ácido láctico teniendo como subproducto gas carbónico, esto se realiza mediante una segunda fermentación llamada fermentación maloláctica, dando lugar a la desacidificación del vino (Blouin \& Peynaud 2003)

La Figura 10 esquematiza la reacción intracelular llevada a cabo por las BAL para producir ácido láctico a partir del ácido málico mediante la enzima maloláctica (EML).

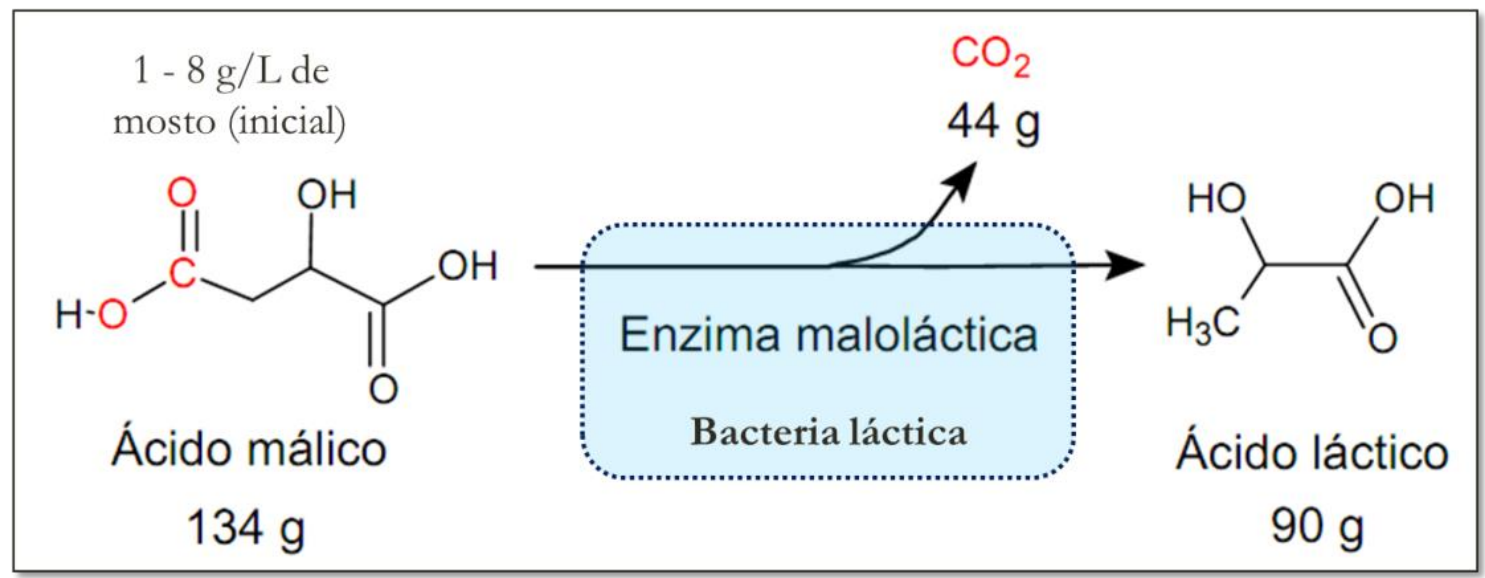

Figura 10. Esquema de la fermentación maloláctica por bacterias ácido lácticas 
En algunos casos, si el desarrollo de estas bacterias no se controla previo, durante y después de la fermentación maloláctica, se puede llegar a tener consecuencias negativas en la calidad del vino, principalmente por la producción de $\mathrm{AB}$ a partir de sus aminoácidos precursores, la síntesis de carbamato de etilo, el cual es un compuesto cancerígeno de carácter genotóxico producido a partir de arginina y la formación de acetiltetrahidropiridina, el cual es un compuesto que provee un olor desagradable a "ratón" (Lehtonen 1996; Blouin \& Peynaud 2003; Araque et al. 2009).

La manera más común de controlar la cantidad de bacterias es mediante la adición del $\mathrm{SO}_{2}$, que, entre otras funciones, es un agente antimicrobiano, ya que reacciona con diversas moléculas intracelulares como lo son las enzimas, aminoácidos, compuestos carbonílicos y diversas proteínas y lípidos, además se fija sobre las membranas celulares y perturba su funcionamiento, por otra parte, fuera de la célula, el $\mathrm{SO}_{2}$ reduce la cantidad de oxígeno disponible en el medio (Blouin \& Peynaud 2003).

\subsection{Producción histamina y otras aminas biógenas en vino}

\subsubsection{Enzima histidina descarboxilasa}

Se ha demostrado que una variedad de organismos procariotas sintetizan la histidina descarboxilasa (HDC), enzima que cataliza la ruptura de enlaces químicos en compuestos orgánicos por un mecanismo distinto a la hidrólisis o la oxidación, por lo que pertenece a la clasificación de las liasas, al ser una enzima que rompe enlaces carbono-carbono en una molécula carboxilo se le denomina descarboxilasa, su precursor o sustrato es el aminoácido histidina por lo cual la nomenclatura de acuerdo a la Comisión de Enzimas (EC por sus siglas en inglés, Ensyme Commission), es EC 4.1.1.22 siendo la enzima responsable de la formación de histamina (Chang \& Snell 1968; Bairoch 2000).

Por mucho tiempo se creía que la producción de histamina en vinos se debía a bacterias de descomposición, sin embargo, la presencia de HDC se ha observado en algunas especies bacterianas enológicas, principalmente de los géneros: Lactobacillus, Oenococcus y Pediococcus. La enzima es altamente específica para L-histidina como sustrato, pero varios análogos de histidina sirven como sustratos de baja afinidad cuando se encuentran en concentraciones elevadas (Chang \& Snell 1968).

La mayoría de las amino descarboxilasas son dependientes de piridoxal-5fosfato (PLP), al igual que varias enzimas que participan en la transformación 
de aminoácidos. Sin embargo, mientras que la HDC de los mamíferos son estimuladas por el PLP, las enzimas bacterianas de Clostridium perfringens, Lactobacillus 30A, Micrococcus sp. y de Oenococcus oeni son independientes de PLP. Las HDC de bacterias Gram positivas, generalmente ácido lácticas, pertenecen a un conjunto de enzimas dependientes de piruvoil, donde el grupo piruvoil ligado a la proteína está implicado en los mecanismos de descarboxilación (Rosenthaler et al. 1965; Riley \& Snell 1968; Snell 1990). El mecanismo por el cual un residuo piruvoil participa en la descarboxilación enzimática de la histidina no se conoce con exactitud, una hipótesis se esquematiza en la Figura 11 la cual fue propuesta por Riley \& Snell (1968).

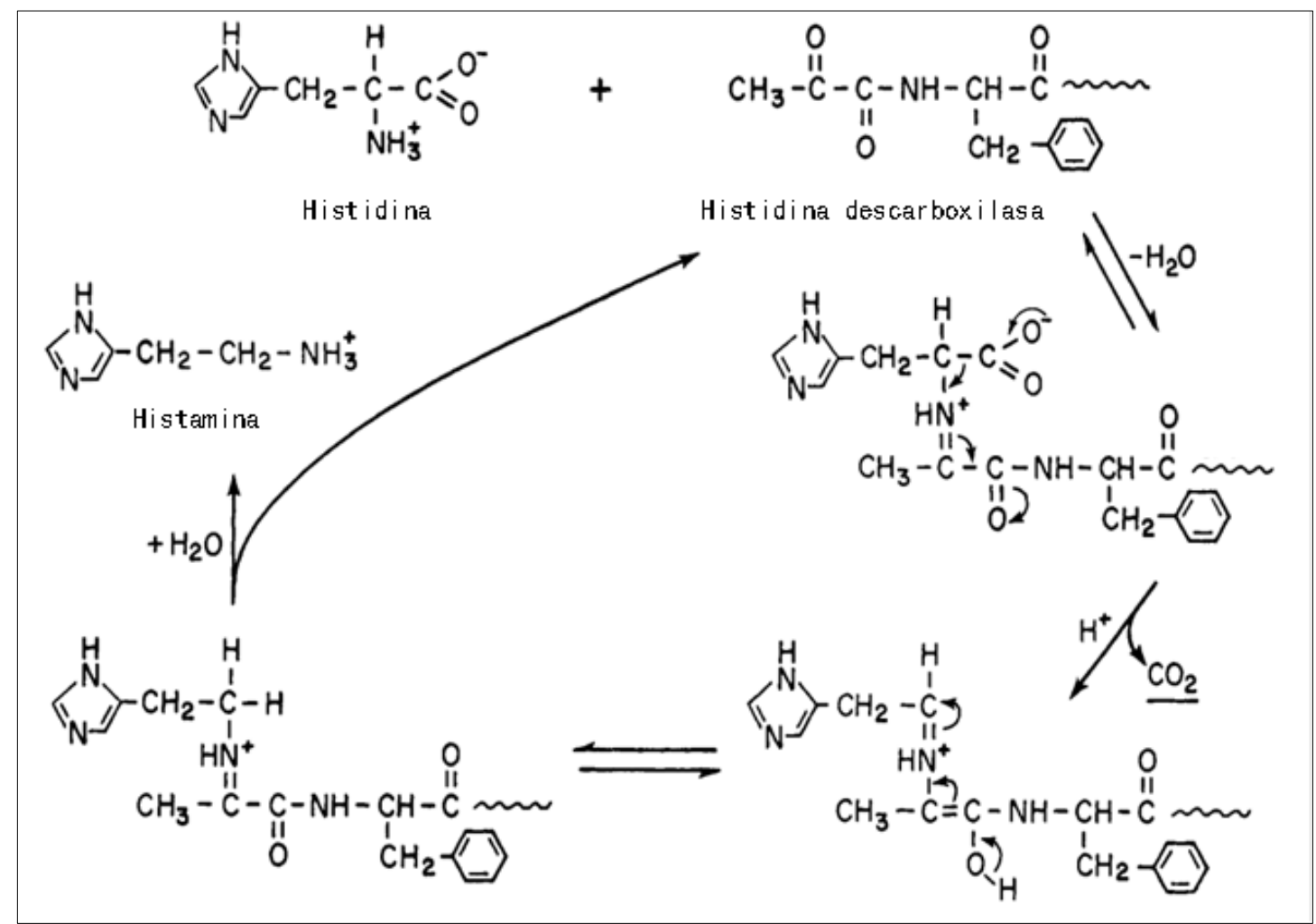

Figura 11. Mecanismo de reacción propuesto para la descarboxilación de histidina Fuente: Riley \& Snell (1968)

Los estudios cinéticos de la enzima pura realizados por Coton, Rollan, \& Lonvaud-Funel, (1998) establecieron que, a un $\mathrm{pH}$ de 7.6, se produce una unión cooperativa entre la enzima y el sustrato, característica de las proteínas que tienen múltiples sitios de unión como en las enzimas compuestas de múltiples cadenas polipeptídicas como la HDC. Además, mediante el cálculo de la constante de Hill, se estableció el nivel de cooperatividad como $n=2$. Por otra parte, ellos detectaron que la propia histamina actúa como inhibidor competitivo. 


\subsubsection{Microorganismos con actividad descarboxilasa}

Existen tres principales requisitos para que exista una formación considerable de $\mathrm{AB}$ en alimentos:

- Disponibilidad de aminoácidos libres

- Condiciones que permitan el crecimiento microbiológico así como la actividad amino descarboxilasa

- Presencia de microorganismos con actividad descarboxilasa

Se sabe que especies de diversos géneros son capaces de descarboxilar uno o más aminoácidos, por ejemplo Bacillus, Clostridium, Escherichia, Klebsiella, Lactobacillus, Pediococcus, Pseudomonas, Salmonella, Shigella, Streptococcus (ten Brink et al. 1990).

Una alta concentración de histamina en el vino es causada por la presencia de la histidina descarboxilasa en algunas BAL (Lonvaud-Funel 2001), por lo que existe un gran interés en la identificación y la caracterización de las bacterias que son capaces de producir histamina en el vino, con el fin de prevenir su síntesis.

Varios grupos de investigación respaldan la hipótesis de que las $\mathrm{AB}$ se forman en la vinificación principalmente por BAL debido a la descarboxilación de aminoácidos libres (Lonvaud-Funel \& Joyeux, 1994; Coton et al. 1998; Moreno-Arribas et al. 2000; Guerrini et al. 2002; Landete, Ferrer et al. 2005a; Lucas et al. 2008).

Maijala (1993), estudió la capacidad de producción de tiramina e histamina por BAL usadas como cultivos iniciadores en alimentos y algunas aisladas de embutidos sobre un medio de cultivo adicionado con los aminoácidos precursores (histidina y tirosina). El análisis mediante HPLC permitió establecer que la única bacteria con la que se detectó producción de tiramina fue Lactobacillus brevis, ninguna produjo histamina.

Lonvaud-Funel \& Joyeux, (1994) estudiaron la producción de histamina con cepas de Leuconostoc oenos (Oenococcus oeni) y observaron que los niveles de dicha amina encontrados en los vinos dependían de la concentración de precursor libre en el mosto así como también de la lisis de las levaduras, que contribuía al enriquecimiento del medio en histidina. Cuando trabajaron con la cepa aislada Lenconostoc oenos 9204 (Oenococcus oeni), observaron que producía mayores cantidades de histamina en los medios nutricionalmente más pobres (sin glucosa, ni ácido málico). 
Landete, Ferrer \& Pardo (2005) reportaron que O. oeni, L. bilgardii, L. mali, Leuconostoc mesenteroides y $P$. parvulus pueden contribuir a la síntesis de histamina en el vino, aunque las especies con mayor producción de dicha amina $(>10$ $\mathrm{mg} / \mathrm{L}$ ) son L. hilgardii y $P$. parvulus. Por otro lado se demostró que las cepas productoras de histamina de $O$. oeni son muy frecuentes en el vino lo cual concuerda con los estudios realizados por Guerrini et al., (2002), quienes también encontraron un alto número de cepas de Oenococcus productoras de histamina en el vino pero con bajos niveles de producción.

Asimismo, las cepas de $L$. brevis fueron capaces de producir tiramina y feniletilamina, pero no histamina, en un medio para la producción de $\mathrm{AB}$ propuesto por Landete, Ferrer, Polo, et al. (2005). En los resultados obtenidos no se observaron BAL capaces de producir cadaverina, triptamina o putrescina. Aquellas cepas que fueron capaces de producir $\mathrm{AB}$ en el medio sintético también lo fueron en vino o mosto, sin embargo las cantidades fueron menores.

Con base en la comparación entre las secuencias de nucleótidos de los genes de las histidina descarboxilasa $(b d c \mathrm{~A})$ de Lactobacillus $30 \mathrm{~A}$ y Clostridium perfringens y entre las secuencias de aminoácidos de la HDC de Lactobacillus buchneri y Micrococcus, Le Jeune et al. (1995) diseñaron juegos de primers (cebadores) para la amplificación del gen en PCR. Posteriormente se demostró con estos primers que el gen codifica un polipéptido de 315 aminoácidos (Coton, Rollan \& Lonvaud-Funel 1998; Lonvaud-funel 1999; Landete, Ferrer \& Pardo 2005).

Algunas reacciones de PCR-múltiple se han desarrollado, logrando la amplificación simultánea de varios genes codificantes para las amino descarboxilasas. La mayoría de estos métodos se describen mediante el uso de ADN extraído como molde para la reacción de PCR, sin embargo, algunos procedimientos han sido descritos mediante el uso de colonias aisladas directamente evitando la etapa de extracción de $\mathrm{ADN}$, como la técnica descrita por Coton \& Coton, (2005) quienes diseñaron nuevos primers universales para la detección de genes $h d c$ en bacterias Gram positivas.

\subsection{Degradación de aminas biógenas}

El ser humano tiene la función de metabolizar las $\mathrm{AB}$ como medio preventivo de intoxicación, este sistema se compone, entre otras enzimas, por amino oxidasas, también presentes en otras células eucariotas (plantas y hongos) y en algunas bacterias (Konno \& Yasumura 1992; Chassandes et al. 1994; Schwelberger \& Bodner 1997; Maintz \& Novak 2007). Por ello, se han 
realizado investigaciones en torno a la actividad amino oxidasa de los microorganismos implicados en la fermentación de alimentos con el fin de prevenir o reducir la acumulación de $\mathrm{AB}$ en los alimentos (Gardini et al. 2005).

Se ha reportado ampliamente la capacidad de degradar las $A B$ por microorganismos en diversos medios de cultivo. Parte de estos microrganismos fueron aislados de alimentos. Tal es el caso del trabajo de Voigt \& Eitenmiller (1978), quienes estudiaron la capacidad de algunas BAL aisladas del queso para degradar histamina y tiramina en medios de cultivo.

Leuschner et al. (1998), estudiaron in vitro la capacidad para degradar histamina y tiramina de algunos microorganismos responsables en la fermentación de alimentos: BAL, Brevibacterium linens, bacterias corineformes, Geotrichum candidum y Micrococcus sp., de la cual Micrococcus varians LTH 1540 mostró la mayor actividad oxidasa para la degradación de la tiramina. Respecto a las BAL evaluadas, se encontraron que de un total de 64, sólo 27 degradaron histamina (19 cepas de Lactobacillus plantarum, 4 de L. sakei, 2 de L. pentosus y 2 de Pediococcus acidilactici) y sólo una degradó tiramina (L. plantarum), aunque todas tuvieron baja actividad.

Martuscelli et al. (2000), evaluaron la capacidad de degradar o producir AB de 50 cepas de Staphylococcus xylosus aisladas de salami producido artesanalmente en Italia, encontraron que 21 de 26 cepas disminuyeron la histamina y/o la tiramina en buffer de fosfato ( $\mathrm{pH} 7$ ).

En ese mismo año, Dapkevicius et al. (2000), mostraron que algunas cepas de Lactobacillus sakei y Lactobacillus curvatus aisladas de pescado eran capaces de degradar histamina en caldo MRS suplementado con dicha amina.

En 2002, Gardini et al., lograron reducir concentraciones de tiramina, espermina y espermidina en embutidos secos inoculando L. sakei G20 y S. xylosus S81. Más tarde, en 2007, Yongsawatdigul et al., describen que la inoculación de Virgibacillus sp. SK33 en la fermentación de salsa de pescado tailandesa reduce a la mitad el contenido de histamina.

García-Ruiz et al. (2011), estudiaron la actividad desaminadora de 85 cepas de BAL, detallando que, en medio de cultivo, la cepa con mayor actividad de degradación fue de $L$. casei, disminuyendo el $54 \%$ de histamina, $55 \%$ de tiramina y $65 \%$ de putrescina. Adicionalmente se estudió el efecto para degradar las tres aminas mencionadas durante la FML a nivel laboratorio, donde sólo L. casei tuvo una degradación de histamina significante del 16\% comparado con la concentración inicial. 
Además de los microorganismos autóctonos, las amino oxidasas purificadas también han sido utilizadas para reducir el contenido de $\mathrm{AB}$ en los alimentos. Las condiciones físico-químicas del vino, principalmente un $\mathrm{pH}$ bajo, previenen el desarrollo y la actividad de la mayoría de las bacterias presentes, así como el rendimiento óptimo de la mayoría de las amino oxidasas. Cueva et al. (2012) encontraron una fracción extracelular de Penicillium citrinum capaz de degradar histamina, tiramina y putrescina en el vino. Sin embargo, la mayoría de los hongos, incluyendo algunos P. citrinum producen micotoxinas (Rundberget et al. 2004) o enzimas extracelulares que pueden causar el oscurecimiento de los vinos (König et al. 2009). En contraste, las BAL no producen este tipo de toxinas y muchas de ellas se consideran GRAS, por lo que se prefiere su uso en la fermentación de alimentos.

Callejón, Sendra, Ferrer, \& Pardo, (2013), realizaron una investigación para determinar la actividad enzimática responsable de la degradación de histamina en vino causada por BAL enológicas, su identificación y la evaluación de la aplicabilidad para reducir dicha amina. Los resultados mostraron que $53 \%$ de los 76 extractos celulares mostraron la actividad de interés. La cuantificación de la capacidad para degradar la histamina se puso a prueba en un medio sintético y en el vino, donde la mayoría de las bacterias analizadas fueron capaces de degradar tres diferentes AB. Las enzimas responsables de la degradación de la amina se aislaron y purificaron a partir de Lactobacillus plantarum J16 y Pediococcus acidilactici CECT 5930 identificándose como oxidasas. 



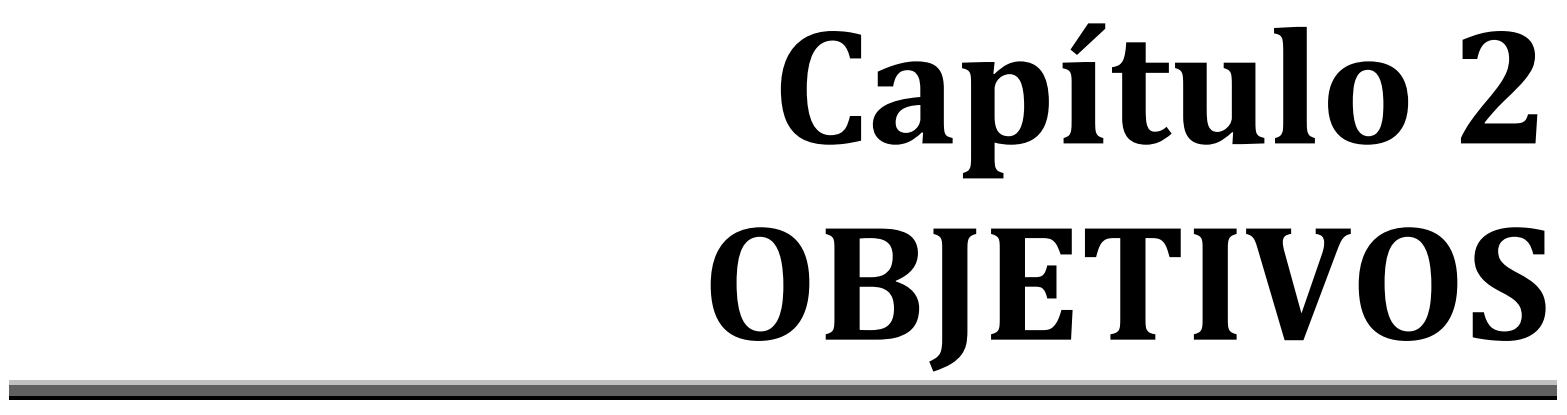





\subsection{General}

Aislar y caracterizar bacterias ácido lácticas enológicas de regiones vinícolas mexicanas que sean capaces de influir sobre la presencia de histamina y otras aminas biógenas en medio sintético.

\subsection{Particulares}

Aislar bacterias ácido lácticas presentes en uva, lías y mosto de vino procedentes de vitivinícolas mexicanas

Identificar las bacterias ácido lácticas mediante pruebas de tinción de Gram y catalasa

Caracterizar ciertas bacterias ácido lácticas mediante MALDI-TOF/MS

Realizar una búsqueda de los genes responsables de producir y degradar histamina en ciertas BAL

Estudiar la influencia de las bacterias ácido lácticas sobre la presencia de histamina y otras aminas biógenas en medio sintético 



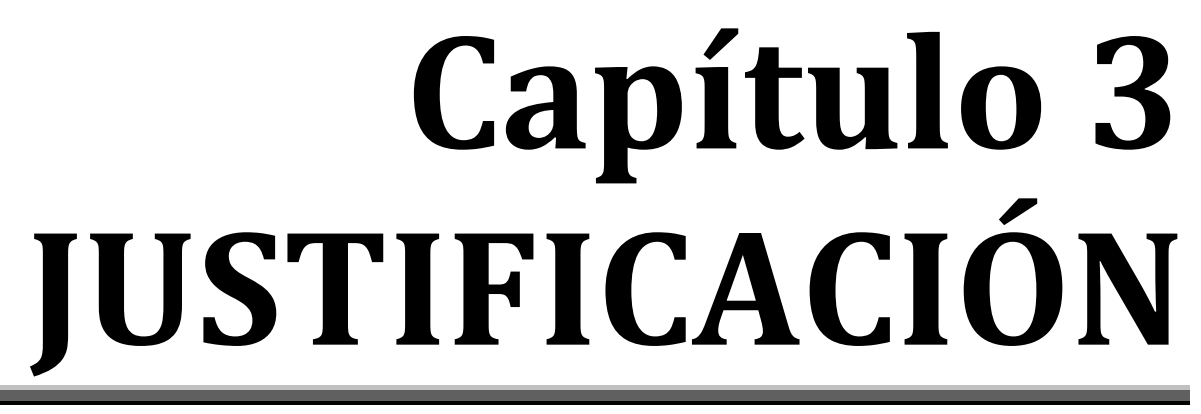



El estudio de aminas biógenas en el vino es de gran interés principalmente por tres razones: el posible riesgo toxicológico de una ingestión de cantidades elevadas de estas sustancias o en personas altamente sensibles, la posibilidad de que exista una relación entre el contenido de cierta amina y las condiciones inadecuadas durante los procesos de producción del vino y, la influencia en su calidad organoléptica.

En México no hay alguna norma que regule la cantidad de histamina o cualquier otra amina biógena en el vino, tema que puede ser crítico ya que en varios países se han impuesto o recomendado límites tanto en los alimentos como en el vino, este hecho ya ha empezado a amenazar las transacciones comerciales sobre exportación y puede llegar a ser más grave en el futuro próximo, especialmente en la industria competitiva actual.

Es importante detectar y estudiar los factores que intervienen en la presencia de aminas biógenas en los diferentes vinos de México para, posteriormente, poder generar alternativas que permitan disminuir su concentración a grado de que no sean perjudiciales para el consumo humano. Además de asegurar que los métodos propuestos no influyan negativamente sobre la calidad del vino. 



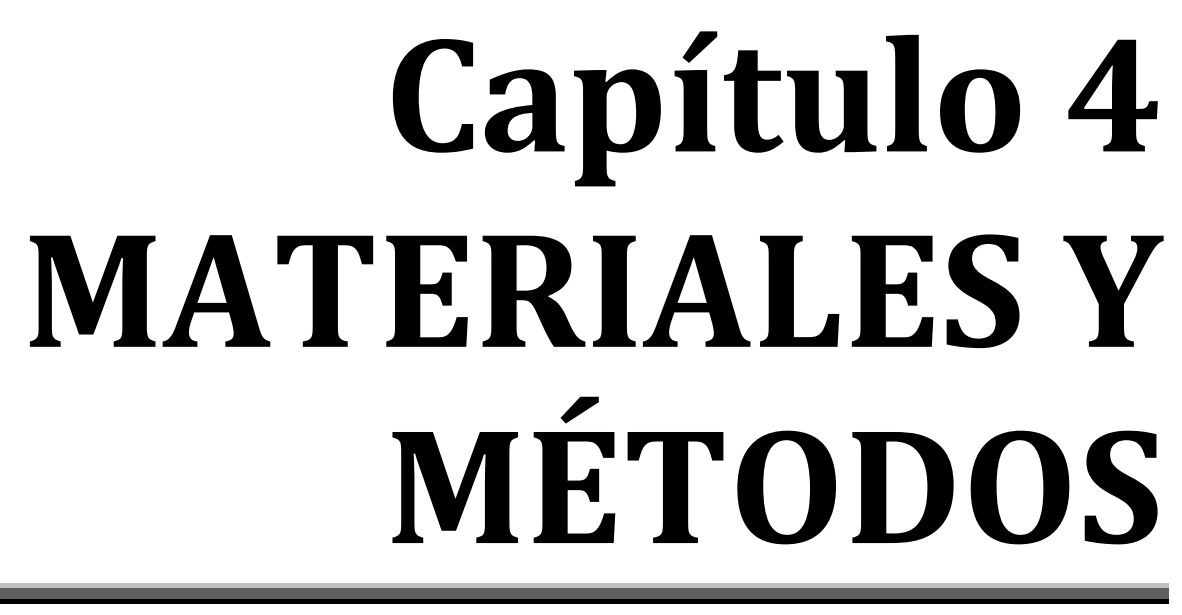





\subsection{Aislamiento de bacterias ácido lácticas}

\section{$\underline{\text { Muestras }}$}

-- VINO (MERLOT) --

El vino varietal Merlot, de la bodega vinícola "Paralelo" (B. C., México) no tuvo ningún tratamiento de añejamiento en barrica, es decir, es un vino joven, sano, obtenido por una vinificación tradicional y almacenado a temperatura de refrigeración $\left(4^{\circ} \mathrm{C}\right)$ hasta su uso.

-- UVA ESTRUJADA (TEMPRANILLO) --

Se utilizaron 6 racimos de uvas de variedad Tempranillo (Zacatecas, México) previamente descongeladas, discriminando las uvas que tuvieran algún tipo de daño visual como magulladuras. Las uvas se estrujaron en un mortero y se tomó como muestra sólo el jugo (Figura 12).

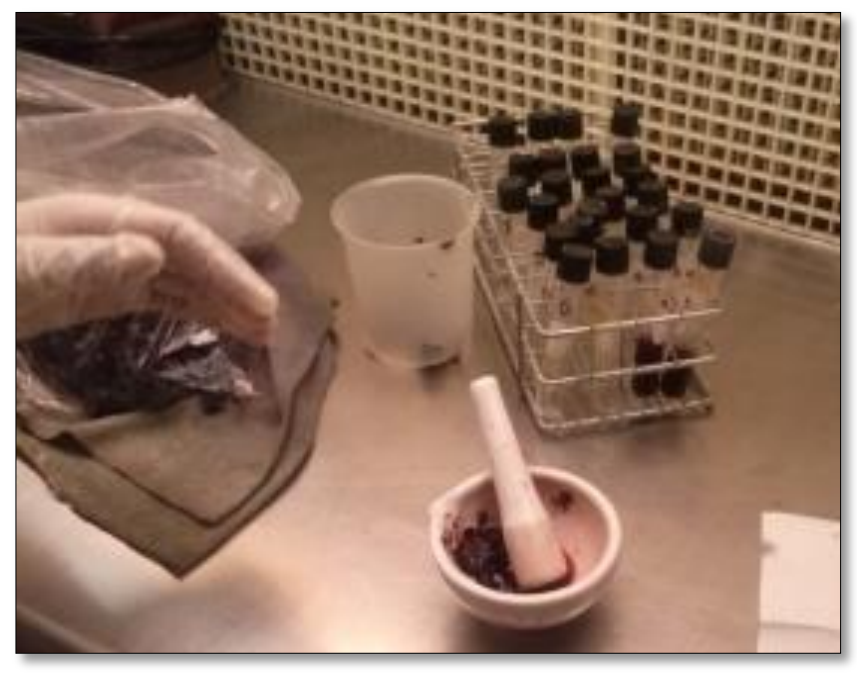

Figura 12. Estrujamiento de uvas

-- VINO (TEMPRANILLO) --

Se estrujaron $2 \mathrm{~kg}$ de uvas Tempranillo (Zacatecas, México) obteniendo el mosto con los orujos, se añadió levadura (Lalvin EC-1118, Lallemand) de acuerdo a las instrucciones de preparación y adición del fabricante, las cuales indican que por cada hectolitro de mosto se adicionan $30 \mathrm{~g}$ de levadura seca con previa activación en un poco de agua a $28{ }^{\circ} \mathrm{C}$ durante 10 min. El mosto con levadura y hollejos se colocó en un fermentador y se mantuvo a una temperatura de $25{ }^{\circ} \mathrm{C}$ por 12 días para llevar a cabo tanto la fermentación alcohólica como la maloláctica. Al menos 3 veces al día se agitó el fermentador para que existiera mayor transferencia de compuestos desde los orujos hacia el mosto (Figura 13) 


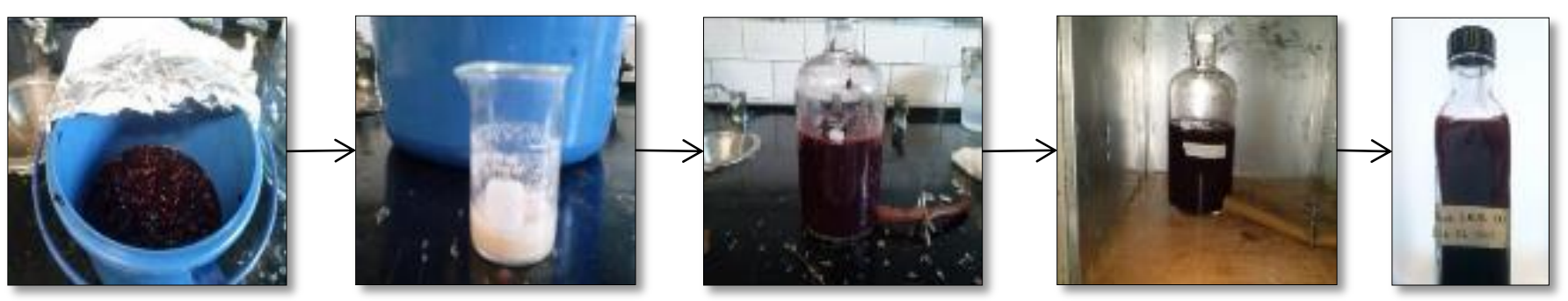

Figura 13. Preparación de vino

El mosto se filtró utilizando gasas, se desecharon los orujos y se recolectó, en una campana de flujo laminar, únicamente la parte líquida (Figura 14).

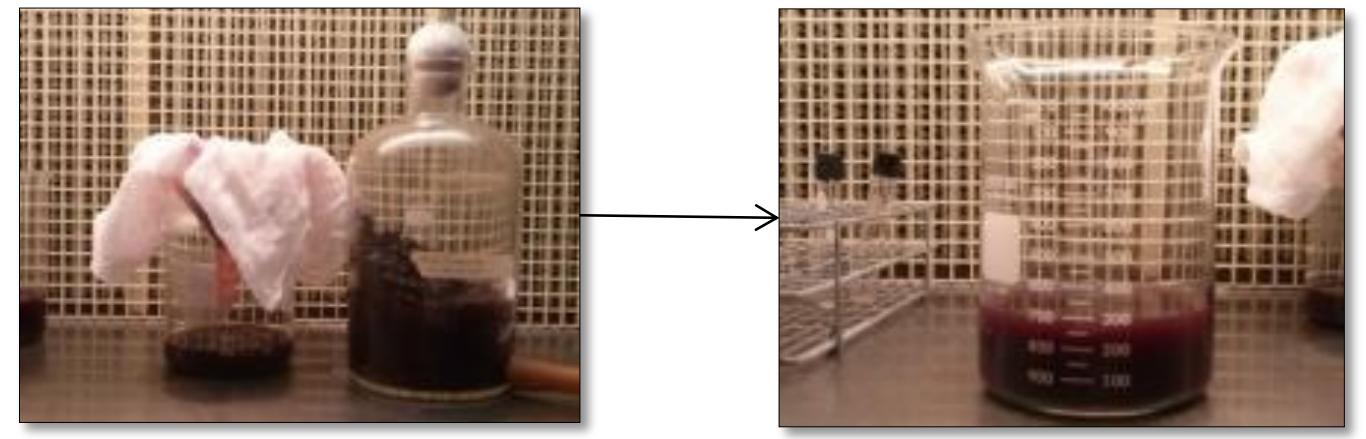

Figura 14. Filtración de vino

Para esta microvinificación no se adicionó $\mathrm{SO}_{2}$ ya que una de las características enológicas de éste compuesto químico es su actividad antimicrobiana. Según De Rosa (1988), al no contar con un agente que controle el desarrollo bacteriano, la actividad de las BAL inicia en los primeros días de la fermentación alcohólica llevándose conjuntamente la fermentación maloláctica.

-- LÍAS DE VINO (TEMPRANILLO) --

Las lías se obtuvieron de la parte sedimentada de la microvinificación con uvas Tempranillo de Querétaro, México (Figura 15).

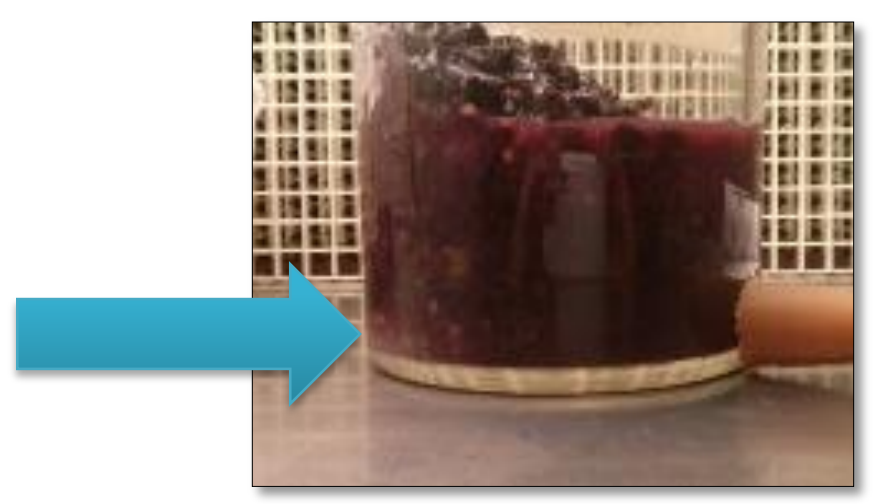

Figura 15. Lías de vino de uva variedad Tempranillo 
-- MEZCLA MOSTO (TEMPRANILLO, ZINFANDEL, CABERNET) --

En la bodega vinícola "Paralelo" (B. C., México), de la vendimia 2013, se recolectaron uvas de tres variedades (Tempranillo, Zinfandel y Cabernet), las cuales, individualmente, se despalillaron y se estrujaron, posteriormente el mosto y los orujos de cada variedad se mezclaron, con la mezcla se realizó una microvinificación con un tiempo de maceración de 5 días y un periodo de fermentación de 7 , finalmente se separaron los hollejos y se envasó.

Análisis microbiológico. Cada muestra se analizó en placa por el método de superficie; se sembró directamente y en diluciones hasta $10^{-3}$ por triplicado, esparciéndose en placas que contenían agar MRS para BAL (BD Bioxon, EUA), modificado del propuesto por De MAN, Rogosa, \& Sharpe, (1960) adicionado con $100 \mathrm{mg} / \mathrm{L}$ de cicloheximida (Sigma-Aldrich, EUA) como inhibidor de levaduras (OIV/OENO 206/2010 2010). Las placas se incubaron por 2 días a $30^{\circ} \mathrm{C}$ en un medio anaerobio para desfavorecer el crecimiento de bacterias acéticas (Figura 16).

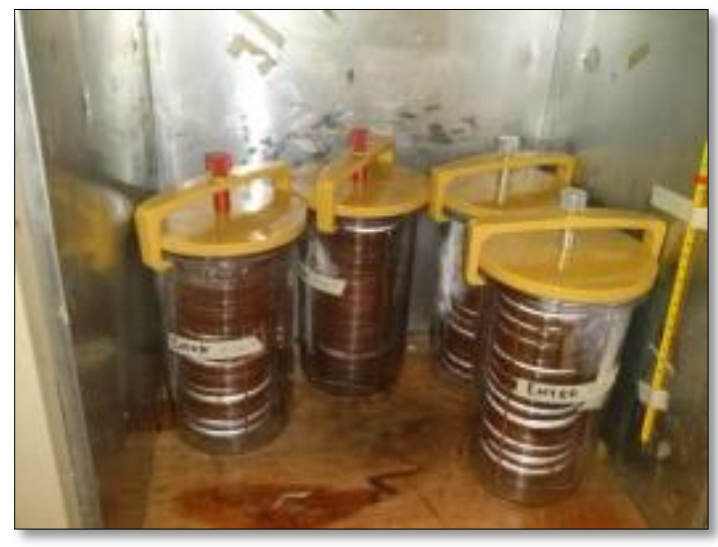

Figura 16. Incubación de bacterias en medio anaerobio

\subsection{Identificación de bacterias ácido lácticas}

\subsubsection{Tinción de Gram}

A partir de las colonias aisladas que hayan crecido en agar MRS modificado, se tomó una asada y se mezcló con una gota de agua destilada sobre un portaobjetos (Madigan et al. (2003), se dejó secar la muestra y se fijó a la flama, se colocó una gota de solución de cristal-violeta, se dejó reaccionar durante un minuto y se enjuagó con agua destilada, se puso una gota de solución Lugol, se dejó reaccionar por 3 minutos y se enjuagó con agua destilada. Se agregó solución alcohol-acetona (5:3), se dejó actuar durante 15-20 s y se enjuagó con agua. Se colocó una gota de solución de safranina, se dejó reaccionar durante 1-2 
min y se enjuagó con agua destilada. Se observó a través del microscopio con el objetivo de inmersión (100x).

\subsubsection{Prueba de Catalasa}

A partir de lo descrito por Madigan et al. (2003), se tomó una asada de las colonias aisladas que crecieron en el agar MRS, se colocó en un portaobjetos, se adicionó con una gota de peróxido de hidrógeno al $3 \%$ preparado inmediatamente antes de su uso y se mezcló perfectamente con la ayuda del asa. Se observó la presencia o ausencia de burbujas a través del microscopio con el objetivo 10x. Las colonias que, de acuerdo a las pruebas realizadas, resultaron ser Gram positivas, y negativas en la prueba de catalasa, se aislaron e incubaron a 30 ${ }^{\circ} \mathrm{C}$ por 2 días en un tubo con agar MRS para posteriormente almacenarlas en refrigeración hasta su posterior uso.

\subsection{Caracterización de bacterias ácido lácticas (MALDI-TOF/MS)}

\section{$\underline{\text { Muestras }}$}

Se utilizaron nueve cepas de bacterias aisladas previamente identificadas como ácido lácticas, además, se solicitaron dos más al Laboratorio de Biopolímeros y al Laboratorio de Bioquímica de Macromoléculas, de la UAM-Iztapalapa (Tabla 5).

Tabla 5. Bacterias elegidas para caracterización mediante MALDI-TOF/MS

\begin{tabular}{c|c}
\hline Cepa & Origen \\
\hline 2 & Lías de Vino (Tempranillo) \\
6 & Lías de Vino (Tempranillo) \\
13 & Lías de Vino (Tempranillo) \\
19 & Uva Estrujada (Tempranillo) \\
20 & Uva Estrujada (Tempranillo) \\
32 & Mezcla mosto (Tempranillo, Zinfandel, Cabernet) \\
33 & Mezcla mosto (Tempranillo, Zinfandel, Cabernet) \\
34 & Mezcla mosto (Tempranillo, Zinfandel, Cabernet) \\
35 & Mezcla mosto (Tempranillo, Zinfandel, Cabernet) \\
A & Mezcla mosto (Tempranillo, Zinfandel, Cabernet) \\
B & Laboratorio de Biopolímeros UAM-Izt \\
\hline
\end{tabular}




\section{$\underline{\text { Soluciones preparadas }}$}

Solución matriz. Se pesaron $2.0 \mathrm{mg}$ de ácido ciano-hidroxicinámico (HCCA) (Bruker Daltonik, Alemania) en un tubo eppendorf. En otro tubo eppendorf se preparó la solución estándar $\left(475 \mu \mathrm{L} \mathrm{H}_{2} \mathrm{O}\right.$ Milli $\mathrm{Q}, 25 \mu \mathrm{L}$ de ácido trifluoroacético, $500 \mu \mathrm{L}$ de acetonitrilo). Se adicionaron $200 \mu \mathrm{L}$ de la solución estándar al HCCA y se agitó en vortex hasta disolver completamente.

Solución de ácido fórmico (H-COOH) al $70 \%$. Se colocaron $30 \mu \mathrm{L}$ de $\mathrm{H}_{2} \mathrm{O}$ y $70 \mu \mathrm{L}$ de ácido fórmico al $100 \%$ en un tubo eppendorf.

Metodología (Propuesta por Bruker Daltonik, Alemania)

Cada cepa se resembró en placas de agar MRS y se colocaron en incubación durante $48 \mathrm{~h}$ a $37^{\circ} \mathrm{C}$ bajo $\mathrm{CO}_{2}$ al $5 \%$. Una vez desarrolladas las colonias se tomó una colonia aislada grande (Figura 17a) y se disolvió en un tubo eppendorf con $300 \mu \mathrm{L}$ de agua Milli Q homogenizando con un vortex. Se adicionaron $900 \mu \mathrm{L}$ de etanol puro (absoluto), nuevamente se homogenizó en vortex para posteriormente centrifugar por 2 min a $13000 \mathrm{rpm}$, inmediatamente después se removió el sobrenadante con pipeta manteniendo el pellet intacto. Nuevamente se centrifugó y se removió el sobrenadante, y se mantuvo cada tubo abierto en la campana de flujo laminar cerca de 10 min para evaporar todo el etanol. Se adicionaron $8 \mu \mathrm{L}$ de la solución de ácido fórmico al pellet y se agitó hasta homogeneidad y se le adicionó el mismo volumen de acetonitrilo, enseguida se mezcló hasta homogeneidad y se centrifugó a $13000 \mathrm{rpm}$ por dos min.

Se tomó $1 \mu \mathrm{L}$ del sobrenadante y se colocó en la tarjeta de análisis del MALDI-TOF/MS (Bruker Daltonik, Alemania) (Figura 17b), se dejó secar y antes de los 10 minutos se colocó $1 \mu \mathrm{L}$ de la solución matriz, se dejó secar y se analizó en el equipo Autoflex III (Bruker Daltonik, Alemania) por duplicado (Figura 17c) utilizando el software FlexControl (Bruker Daltonik, Alemania).

Los espectros de masas se obtienen de acuerdo al tiempo requerido por las proteínas o sus fragmentos para llegar al detector, esto depende de la relación que tenga cada molécula en cuanto a su masa-carga, cada espectro fue comparado con la base de datos MALDI Biotyper (Bruker Daltonik, Alemania) que permite la identificación de microorganismos mediante un puntaje (0.000-3.000).

Posteriormente, se realizó una siembra en un tubo con medio de cultivo de las cepas de interés (asada de $10 \mu \mathrm{L}$ en $9.9 \mathrm{~mL}$ de caldo MRS), se incubaron por $24 \mathrm{~h}$ a $37^{\circ} \mathrm{C}$, después se tomaron $500 \mu \mathrm{L}$ de cultivo y se le adicionaron $500 \mu \mathrm{L}$ de una solución de glicerol/agua $40 \%$ (v/v) para conservarlas a $-80^{\circ} \mathrm{C}$ (Figura 17d). 


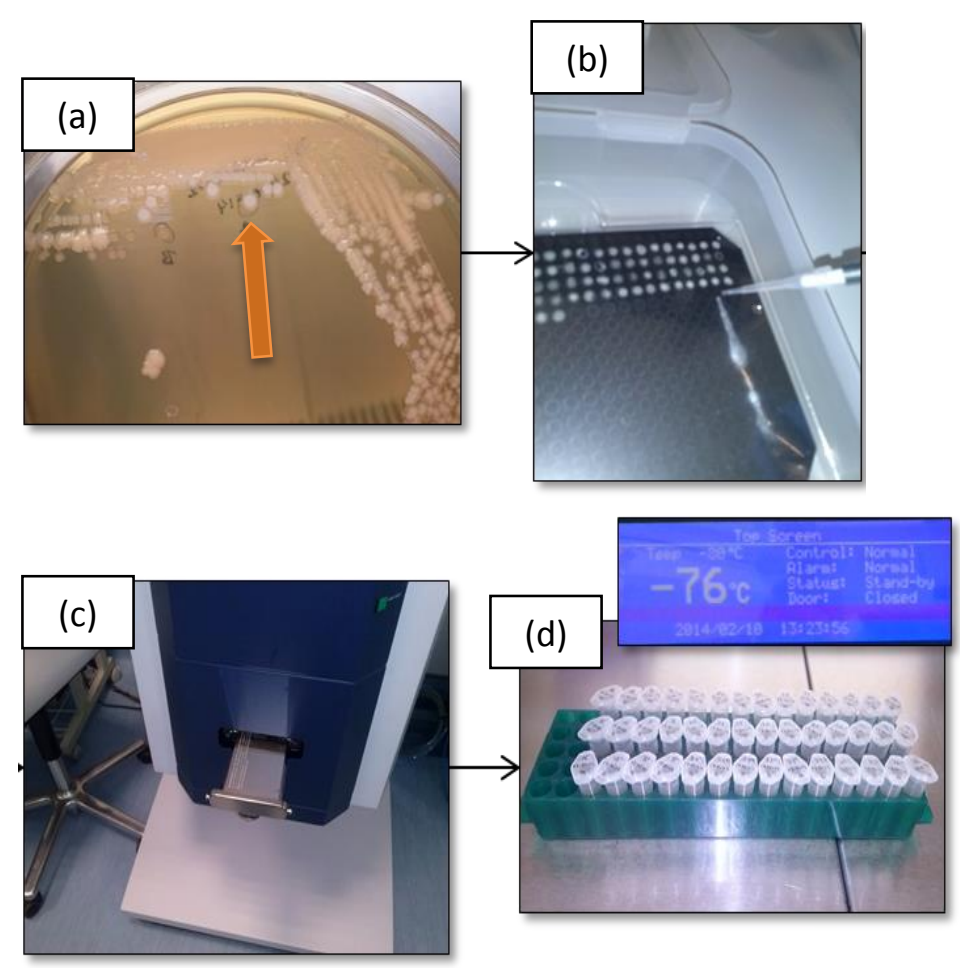

Figura 17. Esquema para la caracterización de cepas

(a) Colonia aislada. (b) Muestra en tarjeta de análisis.

(c) Inicio de análisis en Autoflex III. (d) Conservación de bacterias

Para calibrar el equipo y como control positivo en la validación de los análisis se realizaron ensayos utilizando un estándar de prueba bacteriano (BTS, por sus siglas en inglés, Bacterial Test Standar) con una cepa de Escherichia coli DH5 alfa (Bruker BTS, Bruker Daltonik, Alemania) que muestra un perfil de péptidos y proteínas característico en el espectro de masas (Figura 18).

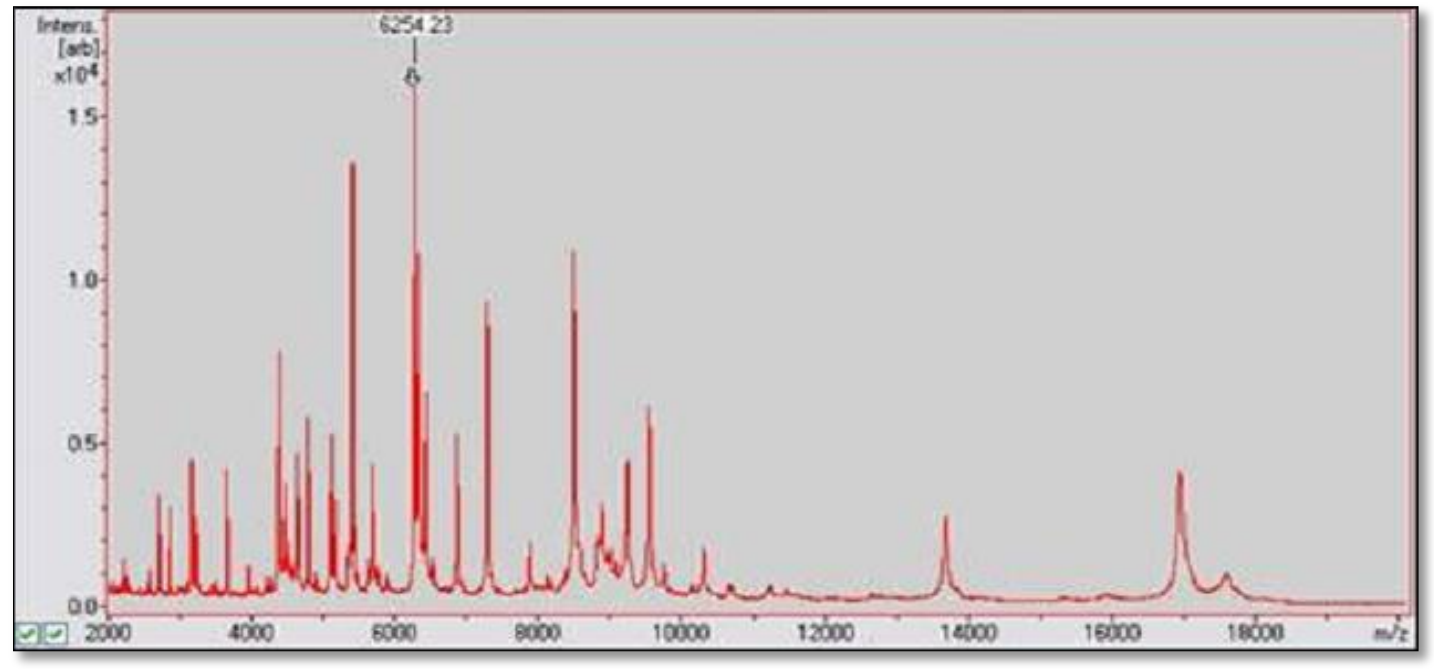

Figura 18. Espectro de masas del BTS (Bruker Daltonik, Alemania) Fuente: Bruker Daltonik (www.bruker.com) 


\subsection{Estudio de la influencia sobre la presencia de aminas biógenas}

\subsubsection{Extracción de ADN}

\section{Muestras}

Se utilizaron 22 cepas previamente identificadas como BAL (Tabla 6).

Tabla 6. Cepas utilizadas para la extracción de ADN

\begin{tabular}{cc}
\hline Cepa & Origen \\
\hline $1,5,19$ & Uva Estrujada (Tempranillo) \\
\hline $2,4,6,7,8,9,10,13,14,15,16,17,18,21,22,23,24,25$ & Lías de Vino (Tempranillo) \\
\hline 12 & Vino (Tempranillo) \\
\hline
\end{tabular}

Cada cepa se activó en medio MRS, las condiciones fueron a $30^{\circ} \mathrm{C}$, durante 20 $\mathrm{h}$ en un sistema anaerobio. Posteriormente se recuperó el pellet celular en tubos eppendorf mediante centrifugación $\left(4^{\circ} \mathrm{C}, 14000 \mathrm{rpm}, 10 \mathrm{~min}\right)$ lavándolo con 200 $\mu \mathrm{L}$ de buffer TE (10 mM Tris-Cl pH 8.0, 1 mM EDTA), se centrifugó de nuevo a las mismas condiciones y se decantó el buffer, almacenando el extracto celular en congelación $\left(-20^{\circ} \mathrm{C}\right)$ hasta su uso.

Los pellets se descongelaron y se resuspendieron en $200 \mu \mathrm{L}$ de buffer TES (10 mM Tris-Cl pH 8.0, $1 \mathrm{mM}$ EDTA, $100 \mathrm{mM} \mathrm{NaCl}$ ), cada pellet se agitó en vortex y se le adicionó lisozima (Invitrogen, EUA), para activar la enzima se incubó cada tubo a $37{ }^{\circ} \mathrm{C}$ durante $90 \mathrm{~min}$ con agitación de $300 \mathrm{rpm}$, posteriormente se le adicionó $1 \mu \mathrm{L}$ de ARNasa (Invitrogen, EUA) y se sometieron a incubación de $37{ }^{\circ} \mathrm{C}$ durante 20 min con agitación de $300 \mathrm{rpm}$, pasado el tiempo se le adicionó $30 \mu \mathrm{L}$ de Dodecil Sulfato Sódico al $10 \%$ (SDS) y $10 \mu \mathrm{L}$ de Proteinasa $\mathrm{K}$ al $20 \%$ (Invitrogen, EUA), se incubaron los tubos a $60{ }^{\circ} \mathrm{C}$ durante $40 \mathrm{~min}$, se adicionaron perlas de vidrio $(50 \mathrm{~mm})$ y $200 \mu \mathrm{L}$ de Fenol:Cloroformo:Isoamílico (PCI) (Sigma-Aldrich, EUA), se agitaron en vortex durante $40 \mathrm{~s}$, se les agregó $100 \mu \mathrm{L}$ de $\mathrm{NaCl} 5 \mathrm{M}$ y $200 \mu \mathrm{L}$ de buffer TE, se centrifugaron recuperando sólo la fase acuosa en un nuevo tubo eppendorf estéril.

Se les adicionó alcohol absoluto (el doble de volumen de lo recuperado) y se agitó ligeramente, se mantuvo en hielo durante $30-60 \mathrm{~min}$, se centrifugaron $\left(4^{\circ} \mathrm{C}\right.$, $14000 \mathrm{rpm}, 10 \mathrm{~min}$ ) y decantaron, se agregó $50 \mu \mathrm{L}$ de alcohol $70 \%$ y sin agitar se centrifugaron $\left(4^{\circ} \mathrm{C}, 14000 \mathrm{rpm}, 10 \mathrm{~min}\right)$ y decantaron nuevamente. Se les adicionó $100 \mu \mathrm{L}$ de agua desionizada y se almacenaron en congelación $\left(-20^{\circ} \mathrm{C}\right)$ hasta su uso. 
Se llevó a cabo la detección de dos genes, el primero $(h d c)$ es el responsable de la producción de histamina, por el contrario, el segundo gen (sufI) es el responsable de degradar dicha amina.

Para la detección del gen $b d c$, se utilizó un par de primers (cebadores) propuestos por Lucas et al. (2008) y para el gen sufI otro par diseñado por Callejón et al. (2013), ambos pares fueron sintetizados en el Instituto de Fisiología Celular (UNAM), a continuación se muestra las cadenas de nucleótidos usadas:

Primers para detección gen $b d c$ (Lucas et al. 2008)

- hdcAf (5’ ATGAAGCCAGGACAAGT'TGG 3’)

- hdcAr (5’ AATTGAGCCACCTGGAATTG 3’)

Primers para detección de gen sufI (Callejón et al. 2013)

- Lac Lp1 (5’ CCCAGAATTGACGACT'TTCC 3')

- Lac Lp2 (5’ GGATGGGATGGATGATGAAGT 3’)

Cada primer se llevó a una concentración final de $10 \mu \mathrm{M}$ para el uso en la amplificación en PCR. Para determinar las condiciones y concentraciones óptimas en la reacción se realizaron 12 experimentos sobre la misma cepa, modificando en la reacción la concentración de $\mathrm{MgCl}_{2}$ (Invitrogen, EUA), Polimerasa (Invitrogen, EUA) y ADN (extraído como se explica en la página 49), las concentraciones elegidas se muestran en la siguiente tabla:

Tabla 7. Concentraciones definidas para PCR

\begin{tabular}{|c|c|c|c|}
\hline Reactivo & Concentración & $\begin{array}{c}\text { Concentración } \\
\text { PCR }\end{array}$ & Cantidad por tubo \\
\hline Agua desionizada & --- --- & $\begin{array}{l}-- \\
-1\end{array}$ & $15.85 \mu \mathrm{L}$ \\
\hline Buffer & $10 \mathrm{x}$ & $1 \mathrm{x}$ & $2.5 \mu \mathrm{L}$ \\
\hline $\mathrm{MgCl}_{2}$ & $50 \mathrm{mM}$ & $3 \mathrm{mM}$ & $1.5 \mu \mathrm{L}$ \\
\hline Primer 1 & $10 \mu \mathrm{M}$ & $0.5 \mu \mathrm{M}$ & $1.25 \mu \mathrm{L}$ \\
\hline Primer 2 & $10 \mu \mathrm{M}$ & $0.5 \mu \mathrm{M}$ & $1.25 \mu \mathrm{L}$ \\
\hline dNTPs & $10 \mathrm{mM}$ & $100 \mu \mathrm{M}$ & $0.25 \mu \mathrm{L}$ \\
\hline Polimerasa & $5 \mathrm{u} / \mu \mathrm{L}$ & $2 \mathrm{u}$ & $0.4 \mu \mathrm{L}$ \\
\hline $\mathrm{ADN}$ & & & $2 \mu \mathrm{L}$ \\
\hline
\end{tabular}

Las condiciones en el termociclador (Thermo scientific, EUA) para la reacción de PCR fueron:

Amplificación del fragmento $h d c$ (Lucas et al. 2008):

Desnaturalización inicial $\left(95^{\circ} \mathrm{C}\right.$ durante $5 \mathrm{~min}$ ), seguido por 35 ciclos de desnaturalización $\left(94^{\circ} \mathrm{C}\right.$ durante $\left.1 \mathrm{~min}\right)$, alineamiento de primers $\left(55^{\circ} \mathrm{C}\right.$ durante 1 
min) y elongación $\left(72^{\circ} \mathrm{C}\right.$ durante $\left.1 \mathrm{~min}\right)$. Las reacciones se completan con $5 \mathrm{~min}$ de elongación a $72{ }^{\circ} \mathrm{C}$ seguido de enfriamiento a $4{ }^{\circ} \mathrm{C}$.

Amplificación del fragmento sufI (Callejón et al. 2013):

Desnaturalización inicial $\left(95^{\circ} \mathrm{C}\right.$ durante $5 \mathrm{~min}$ ), seguido por 40 ciclos de desnaturalización $\left(95^{\circ} \mathrm{C}\right.$ durante $\left.30 \mathrm{~s}\right)$, alineamiento de primers $\left(55^{\circ} \mathrm{C}\right.$ durante 30 s) y elongación $\left(72^{\circ} \mathrm{C}\right.$ durante $\left.30 \mathrm{~s}\right)$. Las reacciones se completan con 5 min de elongación a $72{ }^{\circ} \mathrm{C}$ seguido de enfriamiento a $4{ }^{\circ} \mathrm{C}$.

Los productos de PCR se detectaron por electroforesis en geles con $1 \%$ (p/v) de agarosa/buffer TBE 0.5X (45 mM Tris- $\mathrm{HCl} \mathrm{pH}$ 8.0, ácido bórico 45 $\mathrm{mM}, 1 \mathrm{mM}$ EDTA), el gel fue teñido con bromuro de etidio $(0.6 \mathrm{mg} / \mathrm{mL})$ (BioRad, EUA) para la visualización en luz UV. La masa del producto de PCR se evaluó con un ADN Ladder $1 \mathrm{~KB}$ plus (Invitrogen, EUA).

\subsubsection{Producción de aminas biógenas en medio de cultivo}

Se evaluó la capacidad de producción de AB (histamina, tiramina y putrescina) de cada cepa caracterizada por duplicado mediante la descarboxilación de aminoácidos precursores; histidina (Merck, Alemania), tirosina (Merck, Alemania) y ornitina (Sigma-Aldrich, EUA), respectivamente. Para el ensayo se realizaron tres tipos de control;

- Control de crecimiento (12 tubos). Se inocularon $100 \mu \mathrm{L}$ de cada cultivo $\left(\mathrm{UFC} \approx 1 \times 10^{6}\right.$ ) en $9.9 \mathrm{~mL}$ de caldo MRS.

- Control de producción (3 tubos). Se adicionaron los aminoácidos individualmente en $10 \mathrm{~mL}$ de caldo MRS.

- Control de Medio. (1 tubo). Se colocaron $10 \mathrm{~mL}$ de caldo MRS

Para la prueba de la determinación de la capacidad de producción de AB se estandarizó la concentración de cada cepa a $10^{6}$ UFC en $9.9 \mathrm{~mL}$ de medio de cultivo MRS, se agitó en vortex e inmediatamente se agregó cada aminoácido de manera individual, nuevamente se agitó en vortex y se incubó a $30^{\circ} \mathrm{C}$ por 7 días con agitación continua a $80 \mathrm{rpm}$.

La concentración utilizada de histidina y ornitina fue de $5 \mathrm{mg} / \mathrm{mL}$, mientras que de tirosina fue de $2 \mathrm{mg} / \mathrm{mL}$.

Al finalizar los 7 días de incubación, se centrifugó cada tubo y, en una cabina de seguridad biológica tipo II, se recolectó en un tubo estéril el sobrenadante, eliminando la mayor cantidad de pellet celular posible, posteriormente el medio de cultivo se filtró a través de una membrana con poro de $0.40 \mu \mathrm{m}$. 


\subsubsection{Determinación de aminas (RP-HPLC-Fluorescencia)}

Reactivo para la derivación de compuestos. OPA-MCE.

Se pesó en un matraz aforado cubierto de papel aluminio $0.07 \mathrm{~g}$ de ortoftalaldehído (Fluka, Suiza), se agregaron $4.5 \mathrm{~mL}$ de metanol puro y $0.5 \mathrm{~mL}$ de $\beta$-mercaptoetanol (Sigma-Aldrich, EUA), se aforó a $10 \mathrm{~mL}$ con metanol puro (Merck, Alemania).

\section{FASE A.}

Tampón fosfato de sodio pH 9 (Merck, Alemania)

\section{FASE B.}

Fase A $33.3 \%$ (v/v), 2-octanol $0.7 \%$ (v/v) (Fluka, Suiza) y Acetonitrilo 66\% v/v (LAB-SCAN, Polonia)

\section{Solución patrón.}

La solución estándar de $\mathrm{AB}$ se preparó en una mezcla agua-etanol (60/40 $\mathrm{v} / \mathrm{v}$ ), en una concentración indicada en la Tabla 8:

Tabla 8. Concentración aminas biógenas en la solución estándar

\begin{tabular}{cc}
\hline Amina (Fluka, Suiza) & $\begin{array}{c}\text { Concentración } \\
(\mathbf{g} / \mathbf{L})\end{array}$ \\
\hline Histamina dihidroclorada & 1.2 \\
Metilamina hidroclorada & 0.2 \\
\hline Etilamina hidroclorada & 0.2 \\
\hline Tiramina hidroclorada & 0.8 \\
\hline 2-Feniletilamina hidroclorada & 1.0 \\
\hline 1-4 diaminobutano dihidroclorado (Putrescina) & 3.0 \\
\hline 1-5 diaminopentano dihidroclorado (Cadaverina) & 3.0 \\
\hline
\end{tabular}

Se aplicó la técnica de RP-HPLC propuesta por Marcobal et al. (2005), utilizando una bomba (Waters 600, Waters, EUA), un detector de Fluorescencia (1046-A, HP) y un inyector automático (Waters 717 plus, Waters, EUA) controlado por el software Empower Pro, (Waters, EUA), la separación cromatográfica se llevó a cabo en una columna Nova-Pack C 18 (largo 150 mm, 
diámetro interno $3.9 \mathrm{~mm}$, tamaño de poro $60 \AA$, tamaño de partícula $4 \mu \mathrm{m}$, Waters, EUA).

Se configuró el inyector para que existiera una reacción precolumna que permitiera generar el derivado fluorescente, con $6 \mu \mathrm{L}$ de tampón borato $0.4 \mathrm{M}$ pH 10.5 (Merck, Alemania), $12 \mu \mathrm{L}$ de la solución OPA/MCE y $16 \mu \mathrm{L}$ de muestra, manteniéndose en el loop (con capacidad de $200 \mu \mathrm{L}$ ) por un minuto antes de llegar a la columna.

La detección de los derivados se realizó a $25{ }^{\circ} \mathrm{C}$ mediante un gradiente de elución de fases, tal y como se observa en la Tabla 9.

Tabla 9. Gradiente de fase móvil

\begin{tabular}{cccc}
\hline $\begin{array}{c}\text { Tiempo } \\
(\mathrm{min})\end{array}$ & $\begin{array}{c}\text { Flujo } \\
(\mathrm{mL} / \mathrm{min})\end{array}$ & $\% \mathrm{~A}$ & $\% \mathrm{~B}$ \\
\hline 0.0 & 0.01 & 70.0 & 30.0 \\
5.0 & 0.10 & 70.0 & 30.0 \\
6.0 & 0.80 & 70.0 & 30.0 \\
20.0 & 0.80 & 50.0 & 50.0 \\
60.0 & 0.80 & 20.0 & 80.0 \\
61.0 & 0.80 & 70.0 & 30.0 \\
80.0 & 0.80 & 70.0 & 30.0 \\
82.0 & 0.00 & 70.0 & 30.0 \\
\hline
\end{tabular}





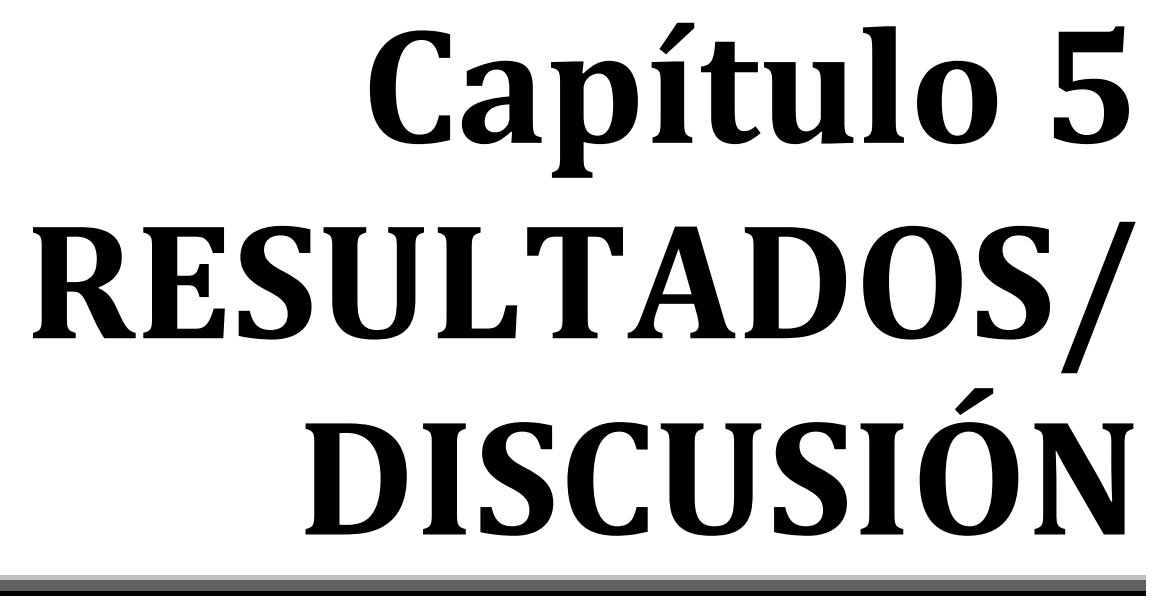





\subsection{Aislamiento e Identificación de bacterias ácido lácticas}

Para el estudio, se aislaron bacterias de diferente origen enológico, realizando pruebas presuntivas para determinar la existencia de BAL (Tabla 10). Al igual que varios autores (Rodas et al. 2003; Moreno-Arribas \& Polo 2008; Bravo-Ferrada et al. 2013), se detectaron y se enumeran (números arábigos) las bacterias con características ácido lácticas debido a su tinción violeta al realizar la prueba de tinción de Gram (prueba positiva), así como la carencia de la enzima "catalasa", la cual cataliza la reacción para descomponer el peróxido de hidrógeno liberando oxígeno (prueba negativa).

Las condiciones de anaerobiosis y la presencia de cicloheximida en el medio se establecieron para inducir el crecimiento de las bacterias de interés y evitar o reducir el desarrollo de bacterias acéticas y levaduras (Madigan et al. 2003; Hernández-Orte et al. 2008; Coton et al. 2010; Capozzi et al. 2012;).

La mayoría de las bacterias que no presentaron características ácido lácticas pertenecen al grupo de bacterias acéticas (numeración romana), ya que son Gram negativas y cuentan con la presencia de catalasa, además, junto con las levaduras y las BAL, son un grupo que predomina en la vinificación (Blouin \& Peynaud 2003; Suárez \& Íñigo 2004; Osborne \& Edwards 2005; König et al. 2009).

Tabla 10. Identificación de bacterias ácido lácticas

\begin{tabular}{|c|c|c|c|c|c|}
\hline Muestra & \# Cepa & Tinción Gram & Catalasa & Morfología & $\begin{array}{c}\text { Bacteria } \\
\text { ácido láctica }\end{array}$ \\
\hline \multirow{16}{*}{$\begin{array}{l}\text { Uva estrujada } \\
\text { (Tempranillo) }\end{array}$} & I & - & + & Cocos & $\mathrm{NO}$ \\
\hline & II & - & + & Cocos & $\mathrm{NO}$ \\
\hline & III & - & + & Cocos & $\mathrm{NO}$ \\
\hline & IV & + & + & Cocos & $\mathrm{NO}$ \\
\hline & $\mathrm{V}$ & - & + & Bacilos & $\mathrm{NO}$ \\
\hline & VI & - & + & Bacilos & $\mathrm{NO}$ \\
\hline & VII & + & + & Bacilos & $\mathrm{NO}$ \\
\hline & 1 & + & - & Bacilos & SI \\
\hline & VIII & - & + & Bacilos & $\mathrm{NO}$ \\
\hline & IX & - & + & Bacilos & $\mathrm{NO}$ \\
\hline & $\mathrm{X}$ & - & + & Bacilos & $\mathrm{NO}$ \\
\hline & 5 & + & - & Bacilos & SI \\
\hline & 19 & + & - & Bacilos & SI \\
\hline & XI & - & + & Bacilos & $\mathrm{NO}$ \\
\hline & XII & - & + & Bacilos & $\mathrm{NO}$ \\
\hline & 20 & + & - & Bacilos & SI \\
\hline
\end{tabular}


Tabla 10. Identificación de bacterias ácido lácticas (Cont.)

\begin{tabular}{|c|c|c|c|c|c|}
\hline Muestra & \# Cepa & Tinción Gram & Catalasa & Morfología & $\begin{array}{c}\text { Bacteria } \\
\text { ácido láctica }\end{array}$ \\
\hline \multirow{3}{*}{$\begin{array}{c}\text { Vino } \\
\text { (Tempranillo) }\end{array}$} & 12 & + & - & Bacilos & SI \\
\hline & XIII & - & - & Bacilos & $\mathrm{NO}$ \\
\hline & XIV & - & - & Cocos & $\mathrm{NO}$ \\
\hline \multirow{23}{*}{$\begin{array}{l}\text { Lías de Vino } \\
\text { (Tempranillo) }\end{array}$} & 2 & + & - & Bacilos & SI \\
\hline & 3 & + & - & Bacilos & SI \\
\hline & 4 & + & - & Bacilos & SI \\
\hline & 6 & + & - & Bacilos & SI \\
\hline & 7 & + & - & Bacilos & SI \\
\hline & 8 & + & - & Bacilos & SI \\
\hline & 9 & + & - & Bacilos & SI \\
\hline & 10 & + & - & Bacilos & SI \\
\hline & 11 & + & - & Bacilos & SI \\
\hline & 13 & + & - & Bacilos & SI \\
\hline & 14 & + & - & Bacilos & SI \\
\hline & 15 & + & - & Bacilos & SI \\
\hline & 16 & + & - & Bacilos & SI \\
\hline & 17 & + & - & Bacilos & SI \\
\hline & 18 & + & - & Bacilos & SI \\
\hline & 21 & + & - & Bacilos & SI \\
\hline & 22 & + & - & Bacilos & SI \\
\hline & 23 & + & - & Bacilos & SI \\
\hline & 24 & + & - & Bacilos & SI \\
\hline & 25 & + & - & Bacilos & SI \\
\hline & 26 & + & - & Bacilos & SI \\
\hline & $\mathrm{XV}$ & - & - & Bacilos & $\mathrm{NO}$ \\
\hline & 27 & + & - & Bacilos & SI \\
\hline \multirow{9}{*}{$\begin{array}{l}\text { Mezcla mosto } \\
\text { (Tempranillo, } \\
\text { Zinfandel, } \\
\text { Cabernet) }\end{array}$} & 28 & + & - & Cocos & SI \\
\hline & 20 & + & - & Cocos & SI \\
\hline & 30 & + & - & Cocos & SI \\
\hline & 31 & + & - & Cocos & SI \\
\hline & 32 & + & - & Cocos & SI \\
\hline & 33 & + & - & Cocos & SI \\
\hline & 34 & + & - & Cocos & SI \\
\hline & 35 & + & - & Cocos & SI \\
\hline & 36 & + & - & Cocos & SI \\
\hline
\end{tabular}

La muestra de "Vino varietal Merlot" no presentó crecimiento bacteriano durante la incubación, posiblemente a que la clarificación, filtración y sulfitado inhibieron a dichos microorganismos. Las lías de vino presentaron la mayor cantidad de BAL, con morfología bacilar, mientras que, en la mezcla de mostos, todas las BAL que se desarrollaron tienen morfología de cocos. 


\subsection{Caracterización de bacterias ácido lácticas}

Hasta el momento no existe alguna publicación oficial sobre microorganismos enológicos identificados por MALDI-TOF/MS, sin embargo ésta técnica analítica ha tenido mucha importancia en el área clínica, obteniendo resultados altamente confiables y rápidos.

Se eligieron diez cepas que previamente fueron identificadas como BAL (ver resultados en la página 57), además se solicitaron dos BAL más al Laboratorio de Biopolímeros (Cepa A) y al Laboratorio de Bioquímica de Macromoléculas (Cepa B) de la UAM-Iztapalapa. Todas las cepas analizadas tuvieron un valor mayor a 2.000, lo que sugiere una alta correlación entre sus espectros de masas y los electrónicos de referencia encontrados en la base de datos MSP de MALDI Biotyper (Bruker Daltonik, Alemania), así que, según el Criterio de Aceptación Bruker (BAC por sus siglas en inglés, Bruker Acceptance Criteria), el género y especie determinado en la caracterización de las bacterias es confiable.

En la Tabla 11 se muestra la identificación de 12 cepas de 2 diferentes géneros (6 Lactobacillus y 6 Enterococcus) así como de tres especies distintas (4 L. paracasei, 2 L. brevis y 6 E. faecium), apreciándose que todas pertenecen al grupo de BAL (König et al. 2009), con esto se corroboran los análisis presuntivos de identificación (tinción de Gram, prueba de catalasa y morfología).

Tabla 11. Caracterización de cepas

\begin{tabular}{c|ccc}
\hline Cepa & Origen & Bacteria ácido láctica (cepa) & $\begin{array}{c}\text { Puntaje MALDI- } \\
\text { TOF/MS }\end{array}$ \\
\hline 2 & Lías de Vino (Tempranillo) & Lactobacillus paracasei (A) & $>2.000$ \\
6 & Lías de Vino (Tempranillo) & Lactobacillus paracasei (B) & $>2.000$ \\
13 & Lías de Vino (Tempranillo) & Lactobacillus paracasei (C) & $>2.000$ \\
19 & Uva Estrujada (Tempranillo) & Lactobacillus paracasei (D) & $>2.000$ \\
20 & Uva Estrujada (Tempranillo) & Lactobacillus brevis (B) & $>2.000$ \\
32 & Mezcla mosto (Tempranillo, Zinfandel, Cabernet) & Enterococcus faecium (C) & $>2.000$ \\
33 & Mezcla mosto (Tempranillo, Zinfandel, Cabernet) & Enterococcus faecium (A) & $>2.000$ \\
34 & Mezcla mosto (Tempranillo, Zinfandel, Cabernet) & Enterococcus faecium (D) & $>2.000$ \\
35 & Mezcla mosto (Tempranillo, Zinfandel, Cabernet) & Enterococcus faecium (E) & $>2.000$ \\
36 & Mezcla mosto (Tempranillo, Zinfandel, Cabernet) & Enterococcus faecium (B) & $>2.000$ \\
A & Laboratorio de Biopolímeros UAM-Izt & Lactobacillus brevis (A) & $>2.000$ \\
B & Laboratorio de Bioquímica de Macromoléculas UAM-Izt & Enterococcus faecium (F) & $>2.000$ \\
\hline
\end{tabular}


Según Madigan et al. (2003) y König et al. (2009), L. brevis y E. faecium son heterofermentativos obligados, es decir, los azúcares son fermentados por la vía 6-P-gluconato produciendo ácido láctico, etanol/ácido acético y $\mathrm{CO}_{2}$, mientras que L. paracasei es un Lactobacilos homofermentativo facultativo; las hexosas se fermentan casi exclusivamente a ácido láctico por la vía de EMP, sin embargo estas especies poseen tanto una aldolasa fructosa-1,6-bisfosfato y una fosfocetolasa, en consecuencia, las especies pueden fermentar hexosas y pentosas, así como gluconato. En la presencia de glucosa se reprimen las enzimas de la ruta del 6-P-gluconato.

Varios autores también han identificado éstas especies en algún punto del proceso de vitivinificación; en la Tabla 12 se muestran algunos trabajos realizados utilizando una o más de estas 3 especies enológicas caracterizadas mediante técnicas bioquímicas y de biología molecular, ya que éstas últimas son las más usadas por su precisión basándose en la parte genómica de los organismos para su caracterización.

Tabla 12. Publicaciones con cepas enológicas de L. brevis, L. paracasei y E. faecium

\begin{tabular}{|c|c|c|}
\hline Referencia & Bacteria & Origen \\
\hline Moreno-Arribas \& Lonvaud-Funel 1999 & L. brevis & Vino \\
\hline Rodas et al. 2003 & L. brevis, L. paracasei & Mosto de uva y vino \\
\hline Lucas et al. 2003 & L. brevis & Vino tinto \\
\hline Verde-Calvo 2004 & L. brevis & Vino tinto \\
\hline Landete, Ferrer \& Pardo 2005 & L. brevis, L. paracasei & Vino \\
\hline Marcobal, Martín-Álvarez, et al. 2006 & E. faecium & Mosto de uva \\
\hline Landete et al. 2007 & L. brevis, L. paracasei & Vino \\
\hline Coton et al. 2010 & $\begin{array}{l}\text { L. brevis, L. paracasei, } \\
\text { E. faecium }\end{array}$ & Vino y sidra \\
\hline Mtshali et al. 2010 & L. brevis, L. paracasei & Vino \\
\hline Capozzi et al. 2011 & E. faecium & Vino \\
\hline García-Ruiz et al. 2011 & L. paracasei & Vino joven y mosto de uva \\
\hline González-Arenzana et al. 2012 & L. brevis & Vino \\
\hline Callejón et al. 2013 & $\begin{array}{l}\text { L. brevis, L. paracasei, } \\
\text { E. faecium }\end{array}$ & Vino tinto y mosto de uva \\
\hline
\end{tabular}


Legarraga et al. (2013), quienes evaluaron el rendimiento y costos asociados al MALDI-TOF/MS como una técnica de rutina en los laboratorios, utilizaron 561 cepas con aplicación clínica (281 aerobias y 280 anaerobias), de los cuales 4 fueron Enterococcus spp, 2 Lactococcus spp, 3 Leuconostoc spp y 4 Lactobacillus spp (géneros ampliamente encontrados en el proceso de vitivinificación). Ellos lograron identificar por MALDI-TOF/MS el $95.7 \%$ de cepas aerobias, mientras que en el caso de las anaerobias fue el $86.4 \%$. La tasa de error comparando con la secuenciación del 16S-ARNr fue de $0.39 \%$ en aerobias y $9.4 \%$ en anaerobias. Por otra parte, mencionan que los costos asociados fueron 8 veces menor, además el tiempo de análisis fue de sólo 6 horas en lugar de días, como es lo común al aplicar técnicas moleculares.

Las especies de Lactobacillus casei, Lactobacillus paracasei y Lactobacillus rhamnosus forman un grupo taxonómico altamente relacionado dentro de los Lactobacillus heterofermentativos, por lo que es difícil diferenciarlos utilizando perfiles de fermentación. La clasificación de estas especies fue propuesta por Collins et al. (1989) de acuerdo a la similitud del ADN, partiendo de 5 subespecies de L. casei (L. casei subsp. alactosus, L. casei subsp. casei, L. casei subsp. pseudoplantarum, L. casei subsp. rhamnosus, y L. casei subsp. tolerans).

Ward \& Timmins (1999), con el objetivo de diferenciar estas especies, desarrollaron primers para PCR específicos de cada una, basados en una región del 16S-ARNr, logrando identificar 63 Lactobacillus aislados de queso $(12 \mathrm{~L}$. rhamnosus y $51 \mathrm{~L}$. paracase $)$. En el presente trabajo, con la técnica de MALDI/TOF-MS se identificaron cuatro cepas de Lactobacillus paracasei diferentes con un alto índice de confiabilidad.

\subsection{Influencia de bacterias ácido lácticas sobre las aminas biógenas}

\subsubsection{Extracción de ADN}

En primera instancia se llevó a cabo la extracción de ADN de 23 cepas de bacterias previamente identificadas como BAL de acuerdo a su tinción de Gram y la carencia de catalasa, la Figura 19 muestra la fotografía tomada con luz UV en un gel de agarosa/Buffer TBE 0.5X, teñido con bromuro de etidio $(0.6 \mathrm{mg} / \mathrm{mL})$ de las extracciones de algunas cepas.

En la línea 1 se aprecia el marcador de peso molecular "ADN Ladder $1 \mathrm{~KB}$ plus (Invitrogen, EUA)" y en las líneas 2-11, la extracción de las cepas 14, 15, $16,17,18,19,21,22,23$ y 24 , respectivamente. 
En las líneas 2, 4, 5, 8, 10 y 11 (cepas 14, 16, 17, 21, 23 у 24, respectivamente), se puede apreciar claramente la presencia de ADN en un tamaño cercano a las 12000 pares de bases de acuerdo al marcador. Por otro lado, las líneas restantes muestran una ligera mancha, también cercano a 12000 $\mathrm{pb}$, lo cual indica la presencia de ADN extraído pero en menor cantidad.

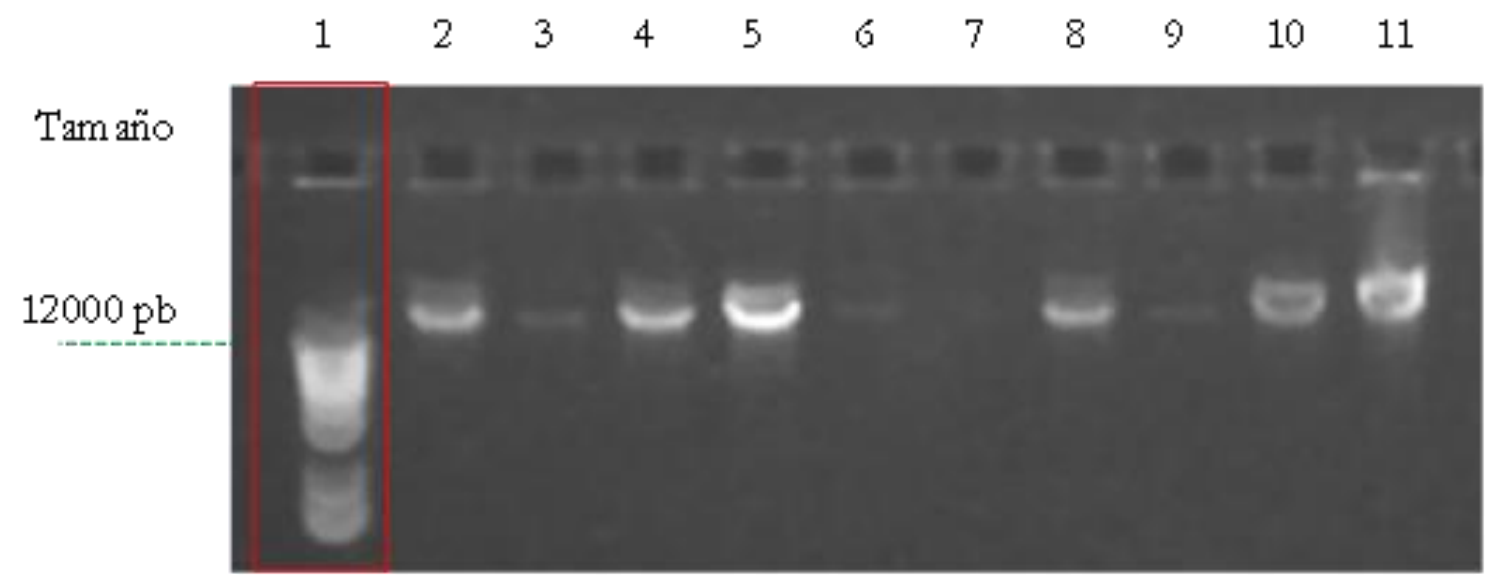

Figura 19. Detección de ADN en cepas aisladas

Línea 1; Marcador ADN Ladder 1 KB plus, Línea 2-11; cepas 14-19 y 21-24, respectivamente

5.3.2 Detección de genes que influyen en la presencia de histamina

\subsubsection{Gen hdcA}

Una vez extraído el ADN de cada cepa se realizaron reacciones por PCR para la amplificación de una secuencia del gen $b d c$ A, en la Figura 20, la cual representa, en cada banda, un fragmento del ADN amplificado. En el caso de la cepa 19 (línea 18), se observa sólo una banda con un peso superior a 1000 $\mathrm{pb}$, tanto en las cepa 18 como en la 25 (líneas 17 y 23), no se observa ninguna banda, por otro lado, las cepas 1, 2, 4-10, 13-17 y 21-24 (líneas 2-10, 12-16, 1922 respectivamente) exhibieron el mismo comportamiento; dos fragmentos de nucleótidos con tamaños de 550 y 350 pb aproximadamente. La cepa 12 (línea 11), también presentó dos bandas, una cercana a 350 y la otra a 500 pb.

La secuencia de los primers hdcAf y hdcAr fue localizada en el gen $b d c \mathrm{~A}$ de algunas BAL, utilizando la base de datos en el sitio web NCBI (http://www.ncbi.nlm.nih.gov), con esto se pudo determinar el tamaño del fragmento a amplificar (83 pb), confirmado por Lucas et al. (2008), quienes utilizaron y propusieron dicho par.

La Tabla 13 exhibe la localización y tamaño ( $\mathrm{pb}$ ) del gen $b d c \mathrm{~A}$, así como la localización del par de primers y el tamaño teórico del fragmento amplificado en algunos microorganismos. 


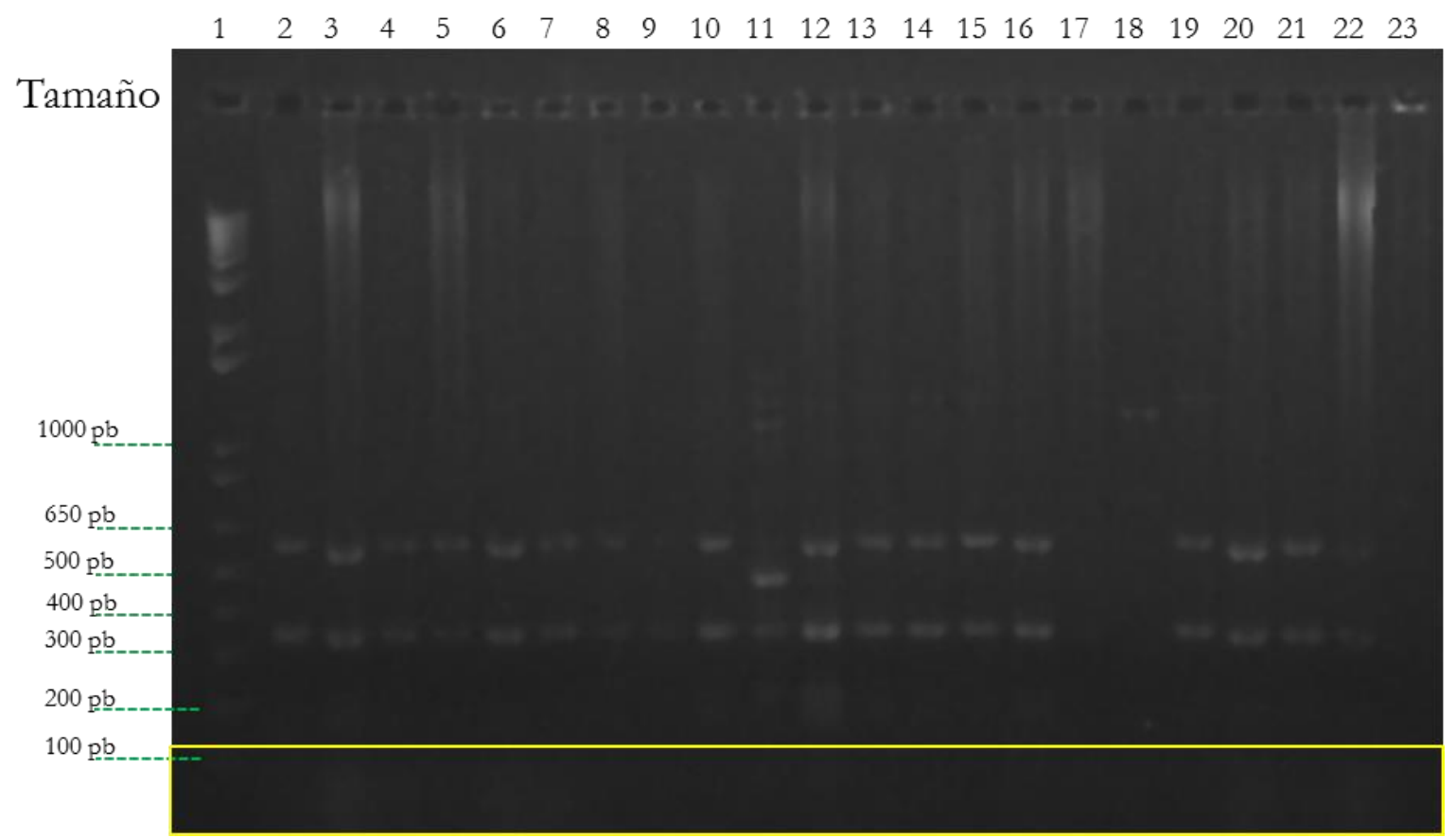

Figura 20. Amplificación de gen $\boldsymbol{h d c A}$

Línea 1; Marcador ADN Ladder 1 KB plus, Línea 2-23; cepas 1, 2, 4-10, 12-19, 21-25

Tabla 13. Presencia del gen $h d c \mathrm{~A}$ en algunas bacterias ácido lácticas

\begin{tabular}{|c|c|c|c|c|c|}
\hline \multirow{2}{*}{ Bacteria } & \multicolumn{2}{|c|}{ Localización Primers } & \multirow{2}{*}{$\begin{array}{l}\text { Tamaño de } \\
\text { fragmento } \\
\text { (pb) }\end{array}$} & \multicolumn{2}{|c|}{ Gen hdcA } \\
\hline & hdcAf & hdcAr & & Localización & Tamaño (pb) \\
\hline T. balophilus & $3483-3502$ & $3547-3566$ & 83 & $2709-3674$ & 966 \\
\hline O. oeni & $778-797$ & $842-861$ & 83 & 19-961 & 951 \\
\hline O. oeni & $760-779$ & $824-843$ & 83 & $1-951$ & 951 \\
\hline L. hilgardii IOEB 0006 & $3017-3036$ & $3081-3100$ & 83 & $2258-3208$ & 951 \\
\hline
\end{tabular}

Fuente: http://www.ncbi.nlm.nih.gov

Como se muestra en la Tabla 13, el segmento del gen de interés tiene un tamaño de $83 \mathrm{pb}$, es decir, la banda que se busca en la fotografía de electroforesis debería aparecer por debajo de la última banda del ADN marcador (recuadro amarillo), sin embargo en ninguna imagen se aprecia esto. Posiblemente es por varias causas, la baja densidad del fragmento que se busca, podría no existir la presencia de ese gen o que hay una baja afinidad en las condiciones trabajadas.

Para eliminar el hecho de que hay poca afinidad por los primers en la PCR, se realizaron otras reacciones, la primera fue una prueba con las cepas 1, 2, 4, 5 y 6 
utilizando una temperatura de alineamiento $5^{\circ} \mathrm{C}$ mayor, es decir de $60^{\circ} \mathrm{C}$, esto con el fin de tener tanto un límite inferior $\left(55^{\circ} \mathrm{C}\right)$ como superior $\left(60^{\circ} \mathrm{C}\right)$, ya que según Kibbe (2007) el intervalo de temperaturas óptimo para éste juego de primers está 56.4 y $58.4^{\circ} \mathrm{C}$.

Por otra parte, se realizó otra prueba reduciendo la concentración de ADN de las mismas cepas hasta $30 \mathrm{ng}$. La medición estimada de ADN en las muestras se realizó por espectrofotometría, utilizando una longitud de onda de $260 \mathrm{~nm}$ (donde se aprecia la absorbancia máxima de ADN), sabiendo la relación de que una $\mathrm{Abs}=0.5$ equivale a una concentración de $25 \mathrm{ng} \mathrm{ADN} / \mu \mathrm{L}$. Las muestras de ADN se diluyeron 1:50 con agua desionizada para su medición, las absorbancias y volúmenes de muestra-agua se ajustaron para obtener $30 \mu \mathrm{L}$ con una concentración final de $15 \mathrm{ng} / \mu \mathrm{L}^{1}$ como se muestran en la Tabla 14.

Tabla 14. Dilución de ADN a 15ng/ $\mu \mathrm{L}$

\begin{tabular}{ccccc}
\hline \# cepa & Abs & ADN $[\mathrm{ng} / \mu \mathrm{L}]$ & Vol ADN $[\mu \mathrm{L}]$ & Vol agua $[\mu \mathrm{L}]$ \\
\hline 1 & 0.1476 & 369 & 1.2 & 28.8 \\
2 & 0.1621 & 405.25 & 1.1 & 28.9 \\
4 & 0.7543 & 1885.75 & 0.2 & 29.8 \\
5 & 0.7589 & 1897.25 & 0.2 & 29.8 \\
6 & 1.3612 & 3403 & 0.1 & 29.9 \\
\hline
\end{tabular}

Los resultados de la amplificación para la detección del gen $b d c$ A probando la temperatura de alineamiento de $60^{\circ} \mathrm{C}$ se muestran en la Figura 21 (líneas 2-6, cepas $1,2,4,5$ y 6 , respectivamente), las líneas 7-11 representan la reacción llevada a cabo con una concentración de $\mathrm{ADN}$ de $30 \mathrm{ng} / \mu \mathrm{L}$ de las mismas cepas.

En el primer experimento no se observa ninguna banda cercana a $83 \mathrm{pb}$ (recuadro amarillo), lo cual es un segundo indicativo de que no hay presencia del gen $b d c$ A. Por otra parte, en el segundo experimento, la cepa 1 (línea 7) exhibió una banda muy tenue cercana a las $350 \mathrm{pb}$, la cual coincide con una de las bandas mostradas con anterioridad, sin embargo ninguna presentó amplificación cerca de los $83 \mathrm{pb}$, nuevamente, a estas condiciones de trabajo, se confirma de que las bacterias analizadas carecen del gen $b d c \mathrm{~A}$.

${ }^{1} \mathrm{La}$ concentración final de $\mathrm{ADN}$ fue de $15 \mathrm{ng} \mathrm{ADN} / \mu \mathrm{L}$, por lo que se adicionaron $2 \mu \mathrm{L}$ de ADN a la mezcla de PCR para contar con una concentración final de $30 \mathrm{ng} / \mu \mathrm{L}$ 


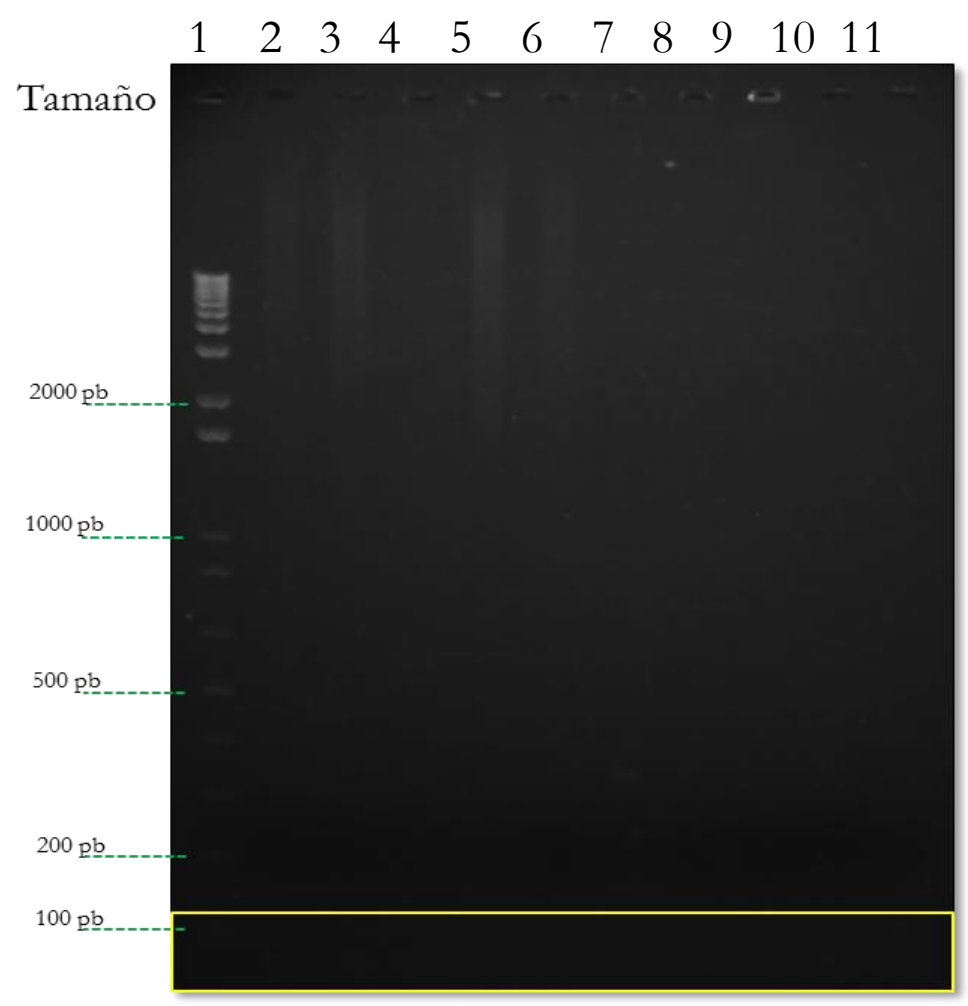

Figura 21. Pruebas de especificidad de primers en amplificación de $\boldsymbol{h} d c \mathrm{~A}$ Línea 1; Marcador ADN Ladder $1 \mathrm{~KB}$ plus, Línea 2-6; cepas 1, 2, 4, 5 y 6 (temperatura de alineamiento de $60^{\circ} \mathrm{C}$ ), Línea 7-11; cepas 1, 2, 4, 5 y 6 (concentración de DNA de 30 ng)

Existen algunos otros juegos de primers que amplifican zonas más grandes del gen $b d c \mathrm{~A}$, los cuales pueden ser utilizados como un método de confirmación (Tabla 15).

Tabla 15. Primers para la detección de bacterias enológicas capaces de producir histamina

\begin{tabular}{ccc}
\hline Primers & Secuencia $\left(\mathbf{5}^{\prime} \mathbf{-} \mathbf{3}\right.$ ) & Referencia \\
\hline CL1 & CCWGGWAAWATWGGWAATGGWTA & Le Jeune et al. 1995 \\
\hline CL2 & GAWGCWGTWGTCATATTWATTTGWCC & Le Jeune et al. 1995 \\
\hline JV16HC & AGATGGTATTGTTTCTTATG & Le Jeune et al. 1995 \\
\hline JV17HC & AGACCATACACCATAACCTT & Le Jeune et al. 1995 \\
\hline JV17 & AGACCATACACCATAACCTTG & Coton, Rollan \& Lonvaud-Funel \\
CL1mod & CCAGGWAACATTGGTAATGGATA & Landete, Ferrer \& Pardo 2005 \\
\hline PHDC1 & CCGTGCGGAAACAAAGAAT & Costantini et al. 2009 \\
\hline PHDC2 & CCAAACACCAGCATCTTCA & Costantini et al. 2009 \\
\hline
\end{tabular}

C: citosina, G: guanina, A: adenina, T: timina, W: adenina o timina.

Fuente: Landete et al. (2010) 
Otra manera de confirmar la inexistencia del gen $b d c \mathrm{~A}$, responsable de la síntesis de la enzima HDC capaz de producir histamina, fue intentando localizar, teóricamente, dicho segmento de nucleótidos en las especies Lactobacillus brevis, Lactobacillus paracasei y Enterococcus faecium, aisladas a partir de diferentes fuentes (resultados en la página 59).

Mediante la secuencia del gen $h d c \mathrm{~A}$ encontrado en Oenococcus oeni (accession number: AJ831547.1) y la herramienta electrónica BLAST (Basic Local Alignment Search Tool, http://blast.ncbi.nlm.nih.gov/Blast.cgi), se encontraron secuencias de nucleótidos dentro del ADN de ciertos microorganismos.

Al realizar la búsqueda, de la Familia Enterococcaceae, el único género al que se detectó la secuencia del gen fue Tetragenococcus, con dos especies:

- T. balophilus

- T. muriaticus

Lo que demuestra que Enterococcus faecium (cepas 32-36 y B) no produce histamina mediante la descarboxilación de histidina.

Por otro lado, del género Lactobacillus, sólo se identificó el gen en las especies:

- L. sakei

- L. bilgardii

- L. buchneri

- L. reuteri

No se localizó dicho gen en las especies L. brevis o L. paracasei, lo que demuestra que todas las cepas caracterizadas no son capaces de producir histamina.

Por otra parte, en términos enológicos, la bacteria más estudiada de las anteriormente enlistada es L. hilgardii (Moreno-Arribas et al. 2003; Lucas et al. 2005; Osborne \& Edwards 2005; Landete et al. 2007; Costantini et al. 2009; Coton et al. 2010), confirmando que tiene la capacidad de producir histamina, lo que demuestra que su presencia en el proceso de vinificación puede llegar a sobrepasar los límites de histamina si no se lleva a cabo un control en las prácticas de vitivinificación. 
Posteriormente se realizó, utilizando los primers Lac Lp1 y Lac Lp2, la amplificación de una secuencia del gen sufI, el cual es responsable de la síntesis de proteínas capaces de degradar histamina en Lactobacillus plantarum (Callejón et al. 2013). En la Figura 22 se muestra la fotografía tomada con luz UV, apreciándose que la cepa 25 (línea 23) no presenta ninguna banda, contrariamente con el resto de las cepas, las cuales al menos presentaron 2 bandas. En las líneas 2, 4, 5, 7-10, 12-16 y 19-21 (cepas 1, 4, 5, 7-10, 13-17 y 2123 , respectivamente), se observa el mismo comportamiento; una banda de un peso cercano a $300 \mathrm{pb}$, otra muy tenue cercana a $400 \mathrm{pb}$, dos bandas por debajo de $1650 \mathrm{pb}$ y una última de $900 \mathrm{pb}$ aproximadamente. Las cepas 2, 18 y 24 (líneas 3, 17 y 22, respectivamente), sólo presentan tres amplificaciones que se detectan a 300, a 400 y 900 pb. En la línea 6 (cepa 6) también se presentan las bandas a 300 y a 400 pb, sin embargo no se aprecian más. La cepa 12 (línea 11) muestra una amplificación de $350 \mathrm{pb}$ aproximadamente, además se observan dos bandas más tenues entre 1200 y 1000 pb. Por último, la cepa 19 (línea 18), presenta dos bandas intensas, una a 600 y 0 tra a 900 pb aproximadamente.

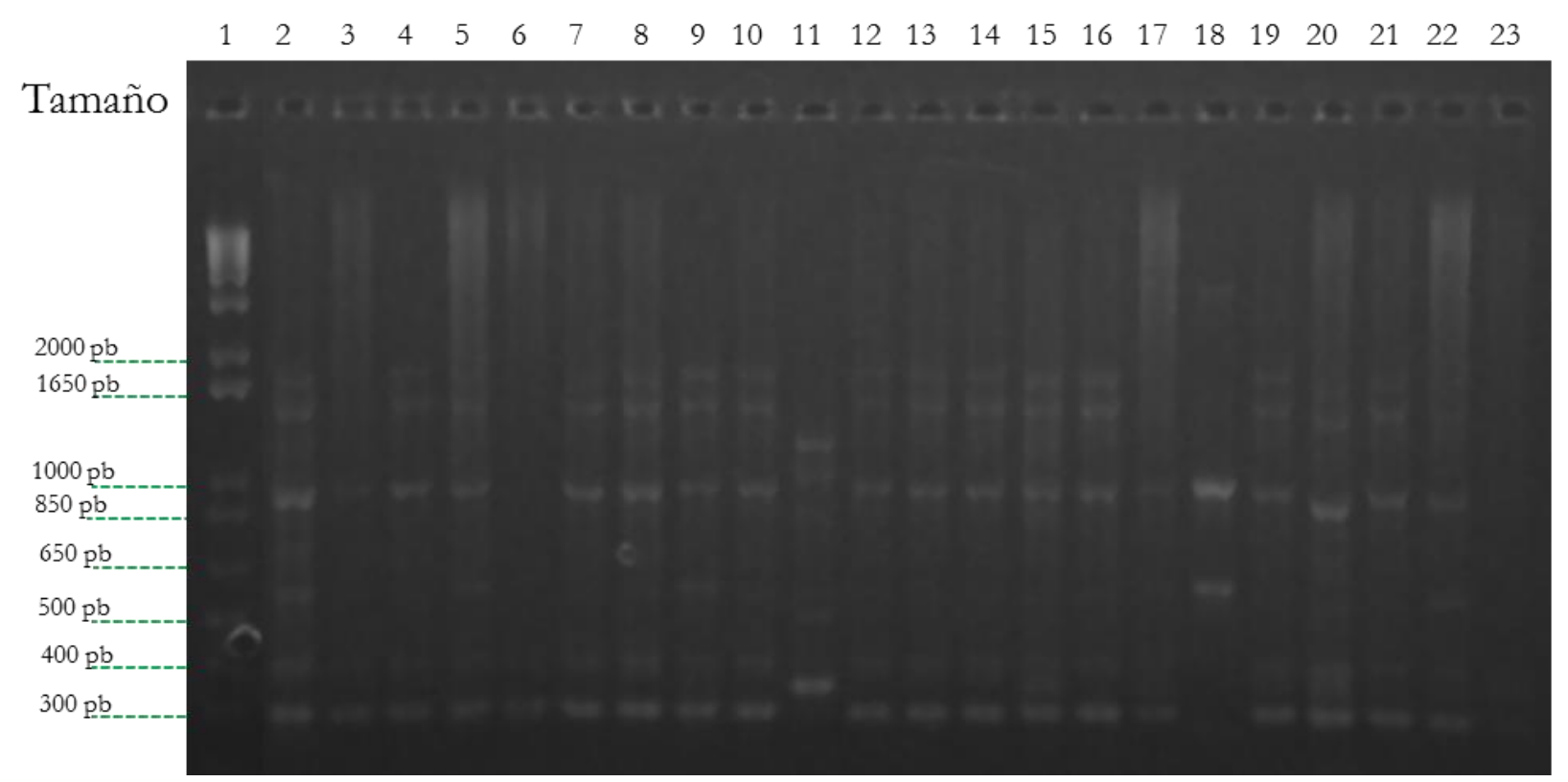

Figura 22. Amplificación de gen suft

Línea 1; Marcador ADN Ladder 1 KB plus, Línea 2-23; cepas 1, 2, 4-10, 12-19, 21-25

La secuencia de los primers Lac Lp1 y Lac Lp2, también fue localizada en el gen sufI de L. plantarum, utilizando la base de datos en el sitio web NCBI (http://www.ncbi.nlm.nih.gov), con esto se pudo determinar el tamaño del fragmento a amplificar que está entre 764 y $771 \mathrm{pb}$ (Tabla 16), confirmado por (Callejón et al. 2013), quienes utilizaron y propusieron dicho par. 
RESULTADOS/DISCUSION

Tabla 16. Presencia del gen sufI en Lactobacillus plantarum

\begin{tabular}{cccc|cc}
\hline \multirow{2}{*}{ Bacteria } & \multicolumn{2}{c|}{ Localización Primers } & Tamaño de & \multicolumn{2}{c}{ Gen sufI } \\
\cline { 2 - 5 } & Lac Lp1 & Lac Lp2 & fragmento \\
& & & Lb) & Tocalización & $\begin{array}{c}\text { Tamaño } \\
(\mathrm{pb})\end{array}$ \\
\hline L. plantarum WCFS1 & $323799-323818$ & $324543-324563$ & 764 & $323497-325002$ & 1505 \\
L. plantarum JDM1 & $333421-333447$ & $334172-334192$ & 771 & $333126-334-631$ & 1506 \\
\hline
\end{tabular}

El fragmento del gen que se busca pesa aproximadamente $770 \mathrm{pb}$, revisando la fotografía de electroforesis (Figura 22), en ninguna línea se observa una banda que coincida con el tamaño, deduciendo que las cepas analizadas no contienen el gen y por dicha razón exista una baja especificidad en el ADN.

Por otra parte, al conocer que las cepas 2, 6, 13 y 19 son Lactobacillus paracasei, se intentó localizar el gen sufI utilizando la herramienta electrónica Basic Local Alignment Search Tool (BLAST, http://www.ncbi.nlm.nih.gov/blast/ Blast.cgi), al igual que en las cepas aisladas Lactobacillus brevis y Enterococcus faecium.

El resultado de la búsqueda del gen sufI utilizando BLAST, demostró que la especie Enterococcus faecium carece de dicha secuencia en su genoma, al igual que Lactobacillus paracasei y Lactobacillus brevis, sin embargo se encontró en algunas bacterias del género Lactobacillus como:

- L. delbrueckii subsp. bulgaricus ND02 (Sun et al. 2011)

- L. crispatus ST1 (Ojala et al. 2010)

- L. plantarum JDM1 (Zhang et al. 2009)

- L. plantarum subsp. plantarum ST-III (Wang et al. 2011)

- L. casei BL23 (Mazé et al. 2010)

De las bacterias enlistadas, L. delbrueckii, L. plantarum y L. casei, han sido encontradas durante el proceso de vitivinificación (Davis et al. 1988; Rodas et al. 2003; Osborne \& Edwards 2005; Rodas et al. 2005; Dicks \& Endo 2009; König et al. 2009; Mtshali et al. 2010; Callejón et al. 2013), quedando la posibilidad de que alguna cepa de estas especies pueda llegar a reducir la cantidad de histamina final en el vino. 


\subsubsection{Producción de aminas biógenas en medio de cultivo}

En primera instancia, se determinó el tiempo de retención (tr) de cada una de las aminas a partir de la inyección de la solución patrón (Figura 23), y así poder detectar su presencia en las muestras inyectadas (Tabla 17).

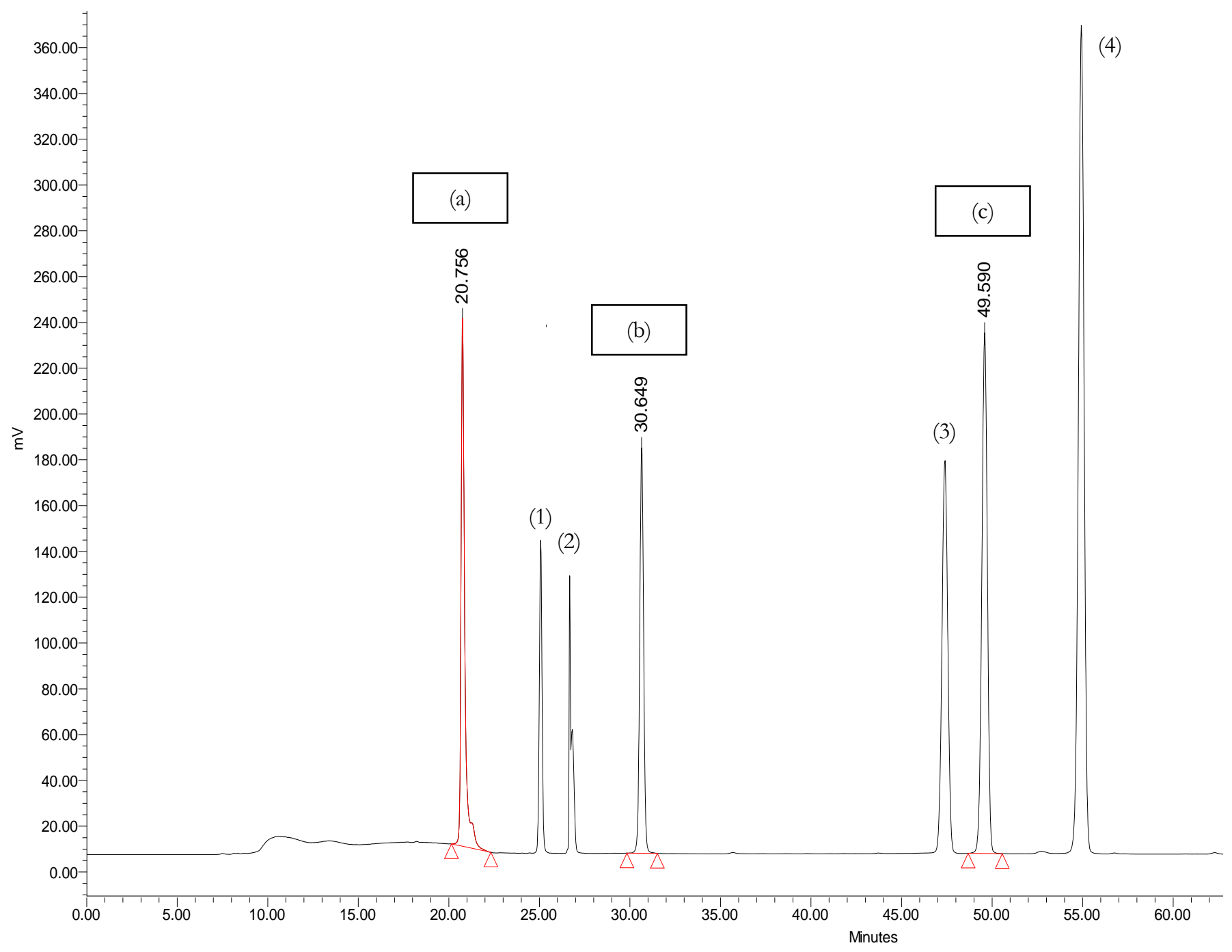

Figura 23. Cromatograma de solución patrón de aminas biógenas

(a) histamina, (b) tiramina, (c) putrescina

(1) metilamina, (2) etilamina, (3) feniletilamina, (4) Cadaverina

Tabla 17. Parámetros cromatográficos de aminas biógenas

\begin{tabular}{|c|c|c|c|c|}
\hline & Amina Biógena & Tiempo de Retención & Área & Altura \\
\hline a & Histamina & 20.756 & 3338042 & 230888 \\
\hline b & Tiramina & 30.649 & 2644436 & 177056 \\
\hline c & Putrescina & 49.590 & 4806123 & 227181 \\
\hline
\end{tabular}


En nuestro estudio, tanto la cepa de L. brevis aislada de uva Tempranillo (B) como la solicitada al Laboratorio de Biopolímeros de la UAM-Iztapalapa (A), tienen la capacidad de producir sólo tiramina de las tres $A B$ evaluadas, esto se puede apreciar en los cromatogramas de cada inyección ya que en los tiempos de retención establecidos para histamina y putrescina no se presenta ningún pico (Figura 24a y 24b), caso contrario al tiempo de retención de la tiramina, que al minuto 30.476 y 30.802 , en L. brevis $\mathbf{A}$ y $\mathbf{B}$, respectivamente, se presenta un pico con una intensidad de señal superior a $1000 \mathrm{mv}$ (Figura 24c).

(a)

(b)
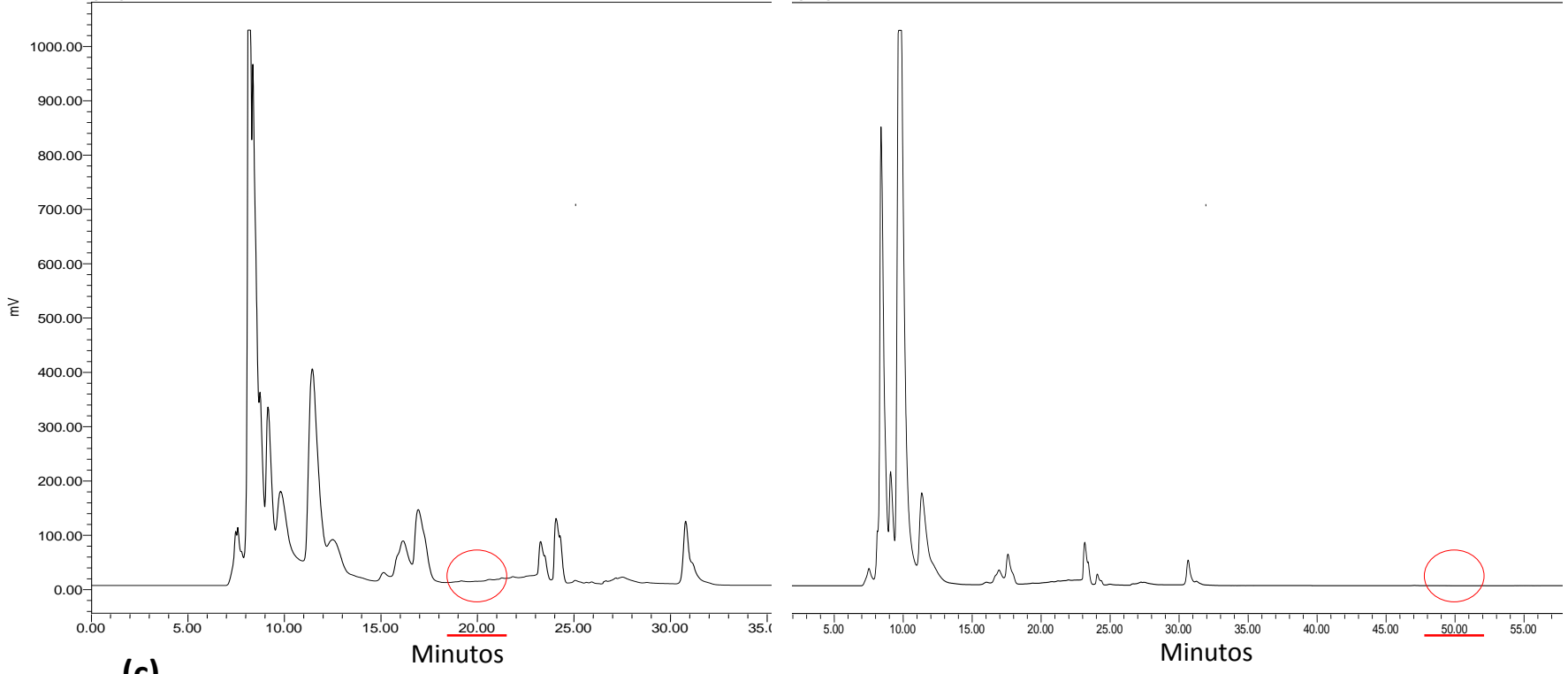

(c)

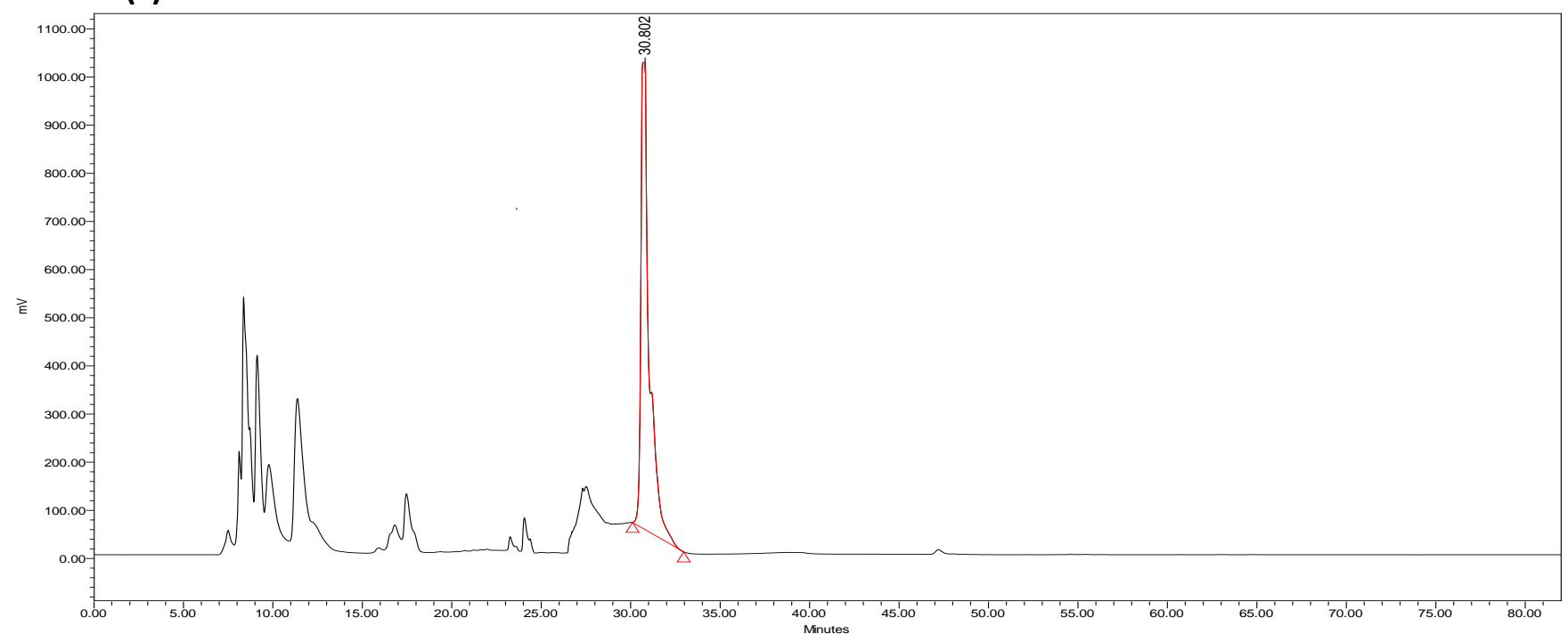

Figura 24. Cromatograma de producción de aminas biógenas por L brevis

(a) Histamina, (b) Putrescina, (c) Tiramina. Se muestran datos de L. brevis B como modelo de representación 
Por otra parte, las cepas de E. faecium, tanto las solicitada al Laboratorio de Bioquímica de Macromoléculas de la UAM-Iztapalapa (F) como las aisladas de mosto de vino (A-E), tuvieron un comportamiento similar entre ellas. En la Figura 25a y 25b se muestra que dichas bacterias no tuvieron la capacidad de producir histamina ni putrescina debido a la ausencia de señal a los tiempos de retención cercanos a 20.5 y 49.5, sin embargo se nota que producen tiramina ya que al min 30.077 se presenta un pico elevado que sobrepasa la escala de detección Figura 25c.

(a)

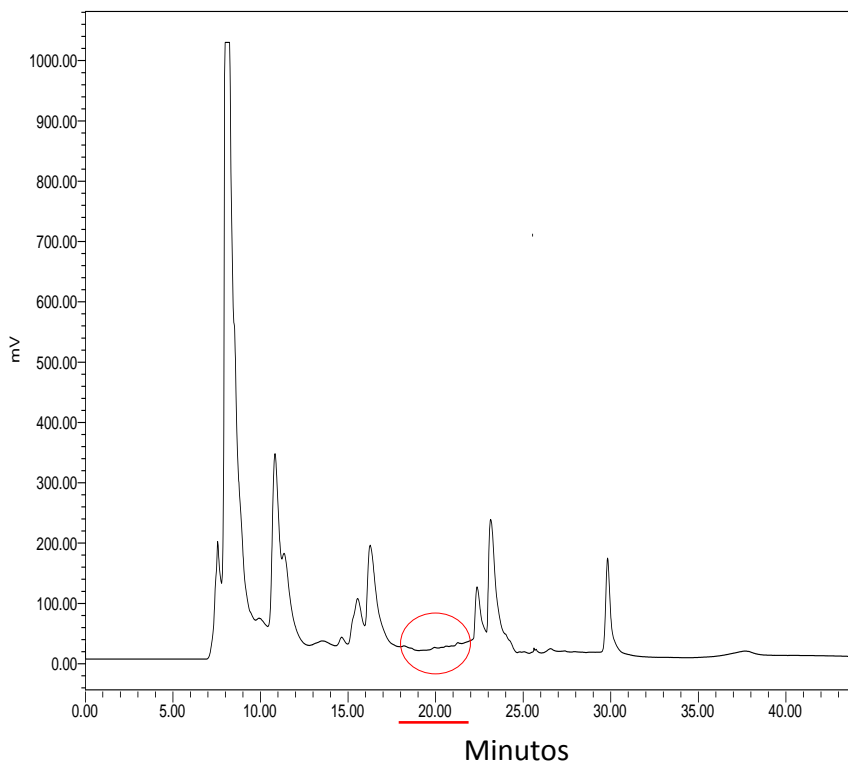

(c)

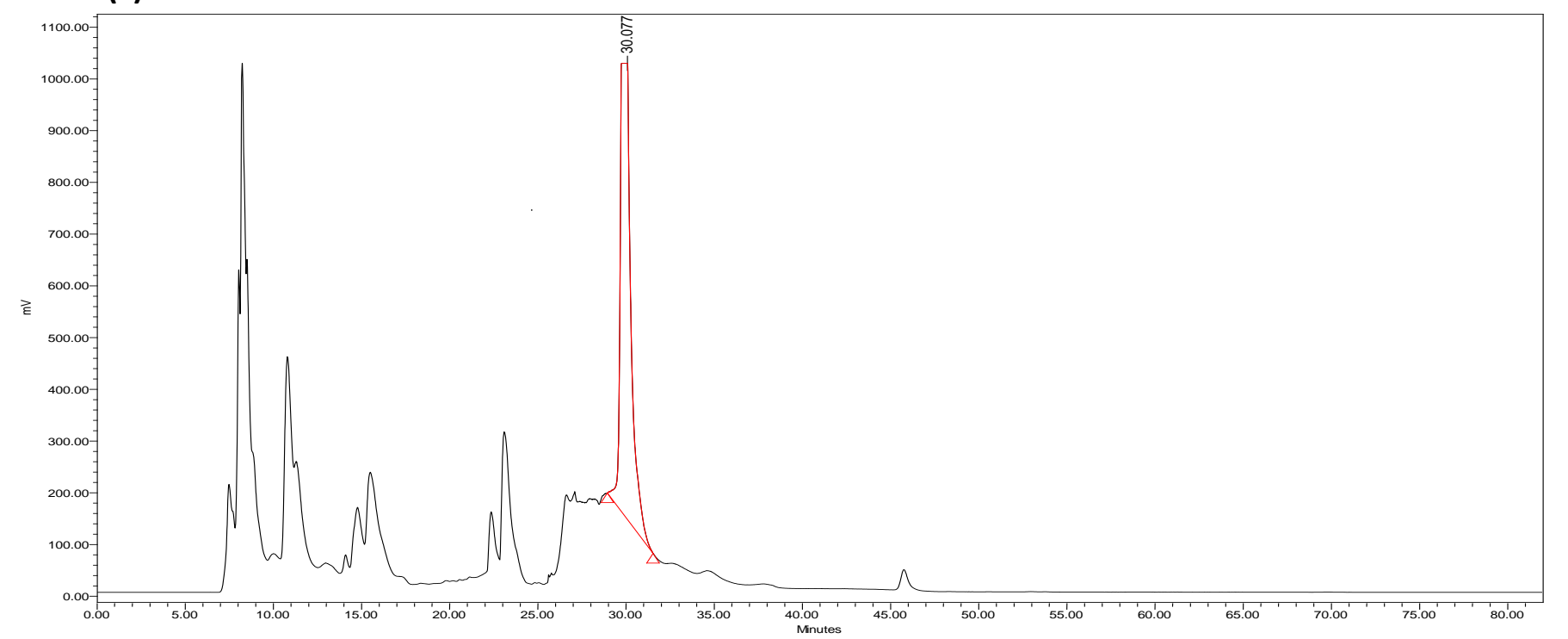

Figura 25. Cromatograma de producción de aminas biógenas por E. faecium

(a) Histamina, (b) Putrescina, (c) Tiramina. Se muestran datos de E. faecium A como modelo de representación 
A continuación se resumen los resultados de la detección de $\mathrm{AB}$ obtenidos al analizar, por RP-HPLC (Marcobal et al. 2005), el medio de cultivo MRS modificado previamente filtrado a $0.4 \mu \mathrm{m}$ (tal y como se describe en la página 51):

Tabla 18. Colección de cepas caracterizadas y su actividad productora de aminas biógenas

\begin{tabular}{c|cccc|ccc}
\hline Bacteria ácido láctica & Hist & Tir & Put & Bacteria ácido láctica & Hist & Tir & Put \\
\hline Lactobacillus paracasei (A) & - & - & - & Enterococcus faecium (A) & - & + & - \\
Lactobacillus paracasei (B) & - & - & - & Enterococcus faecium (D) & - & + & - \\
Lactobacillus paracasei (C) & - & - & - & Enterococcus faecium (E) & - & + & - \\
Lactobacillus paracasei (D) & - & - & - & Enterococcus faecium (B) & - & + & - \\
Lactobacillus brevis (B) & - & + & - & Lactobacillus brevis (A) & - & + & - \\
Enterococcus faecium (C) & - & + & - & Enterococcus faecium (F) & - & + & - \\
\hline
\end{tabular}

La Tabla 18 muestra la presencia (+) o ausencia (-) de histamina, tiramina o putrescina en el medio de cultivo MRS inoculado con cada cepa y acondicionado con cada aminoácido precursor; histidina, tirosina y ornitina, respectivamente. Se puede concretar que ninguno de los inóculos presenta actividad para producir histamina ni putrescina en las condiciones trabajadas, por otra parte, todas las cepas de Lactobacillus brevis y Enterococcus faecium mostraron capacidad de producir tiramina.

Con estos datos, se confirma que ninguna de estas 12 cepas presenta el gen $b d c$, tal y como se aprecia los resultados para la detección de dicho gen (en la página 62), el cual sintetiza la enzima responsable de producir histamina.

Sin embargo, para corroborar los resultados obtenidos, se realizó una búsqueda de las proteínas (enzimas) involucradas en la descarboxilación de los tres aminoácidos precursores (amino descarboxilasas) para cada una de las especies caracterizadas (L. brevis, L. paracasei y E. faecium) y algunas otras bacterias comúnmente encontradas en el vino o en su proceso de producción. Para esto se utilizó la base de datos de NCBI (http://www.ncbi.nlm.nih.gov/) así como la herramienta electrónica BLAST.

La enzima HDC está presente principalmente en Oenococcus oeni (Lucas et al. 2008), de su secuencia de aminoácidos se realizó una búsqueda para conocer algunos otros microorganismos que cuenten con dicha enzima, encontrándose en algunas bacterias de los géneros Tetragenococcus, Staphylococcus, Bifidobacterium, Clostridium y Lactobacillus, entre otros, sin embargo no se encontró en 
Enterococcus, L. brevis o L. paracasei pero sí en L. bilgardii y L. buchneri, bacterias que también han sido aisladas durante la vitivinificación (Moreno-Arribas et al. 2003; Lucas et al. 2005; Osborne \& Edwards 2005; Landete et al. 2007; Costantini et al. 2009; König et al. 2009; Coton et al. 2010). Esto nuevamente demuestra que las cepas analizadas no tienen la capacidad de producir histamina mediante la descarboxilación de histidina.

Por otra parte, al realizar la búsqueda de tirosina descarboxilasa (TDC), se encontró en Enterococcus faecium y Lactobacillus brevis, así como en Lactobacillus plantarum y Pediococcus pentosaceus; especies que también se encuentran en la vinificación (Rodas et al. 2003; Rodas et al. 2005; Araque et al. 2009; García-Ruiz et al. 2009; Bravo-Ferrada et al. 2013; Petri et al. 2013), por el contrario no se encontró en Lactobacillus paracasei. Estos resultados confirman que las únicas especies analizadas en este trabajo que tienen la capacidad de producir tiramina a partir de la descarboxilación de tirosina son E. faecium y L. brevis, tal y como se observa en la Tabla 18, donde se presentan los resultados del ensayo de producción de aminas.

Para encontrar los microorganismos que cuenten con la capacidad de producir putrescina mediante la descarboxilación de ornitina, se realizó la búsqueda de la ornitina descarboxilasa (ODC), no se encontró en L. paracasei ni en E. faecium, lo que confirma nuestros resultados, sin embargo se detectó en $O$. oeni y L. brevis, entre otras bacterias no ácido lácticas.

En este trabajo no se evaluó $O$. oeni, sin embargo sí se determinó la capacidad que tiene $L$. brevis para producir putrescina a partir de la descarboxilación de ornitina, obteniendo un resultado negativo en dos cepas distintas (Tabla 18). Esto discrepa con Romano et al. (2012) y Romano et al. (2014) quienes detectaron la presencia de los genes responsables de sintetizar la enzima ODC en la cepa L. brevis IOEB 9906 proveniente de caña de azúcar, de la colección del Instituto de enología de Bordeaux (IOEB; Bordeaux, Francia) al someterla a un estrés ácido.

Straub et al. (1995), analizaron la capacidad parar producir AB de distintas BAL, entre ellas 33 cepas de L. brevis (de origen no determinado), de las cuales sólo 5 presentaron actividad productora de tiramina y 9 de putrescina mediante la descarboxilación de sus aminoácidos precursores (tirosina y ornitina, respectivamente). Sin embargo Coton et al. (2010) no encontraron, mediante una técnica de PCR, el gen odc en la cepa enológica L. brevis IOEB 9809 (IOEB; Bordeaux, Francia), dicho gen es el responsable de la síntesis de la enzima ODC, no obstante detectaron el gen agdi, el cual codifica para la enzima agmatina deiminasa ( $\mathrm{AgDI})$, capaz de sintetizar putrescina a través de agmatina. 
Esto demuestra que el origen de cada cepa, aunque sea de la misma especie, influye de manera notable sobre las capacidades metabólicas de los microorganismos debido a la tendencia que tienen para adaptarse a los medios en los que se desarrollan, así como lo describen Van de Guchte et al. (2002) y Romano et al. (2014), quienes mencionan que cuando las BAL se encuentran en medios ácidos, desarrollan un sistema de defensa para regular su $\mathrm{pH}$ intracelular (citoplasma), el cual consiste en absorber los protones del medio mediante la descarboxilación de aminoácidos produciendo $\mathrm{AB}$.

En los resultados obtenidos (Tabla 18), se aprecia que las bacterias identificadas como Lactobacillus paracasei no presentaron la propiedad de sintetizar ninguna de las tres aminas en una cantidad detectable por la técnica analítica utilizada. Estos resultados son comparables con otros varios ensayos propuestos por diversos autores; Coton et al. (2010), determinaron, mediante la técnica de HPLC, la capacidad de producción de AB de 810 BAL enológicas y de sidra, confirmando que Lactobacillus paracasei proveniente de vino no produce AB (histamina, tiramina y putrescina), por otra parte, los autores comprobaron la ausencia del gen involucrado para la producción de tiramina ( $t d c$, tirosina descarboxilasa), histamina ( $h d c$, histidina descarboxilasa) y putrescina (odc y agdi, ornitina descarboxilasa y agmatina deiminasa), aplicando un método de PCR múltiple. Los autores también reportan que 12 de las 40 cepas analizadas de $L$. brevis provenientes de vino, y el $100 \%$ de L. brevis de sidra, presentan el gen $t d c$, lo cual indica, como en los resultados presentados y los de otros autores (Maijala 1993; Landete, Ferrer, Polo, et al. 2005; Landete et al. 2007), que ciertas cepas de dichas especies tienen la capacidad de producir tiramina.

Landete et al. (2007) encontraron que en vinos con alta cantidad de tiramina se encontraban presentes bacterias como Lactobacillus hilgardii y Lactobacillus brevis, para las cuales, entre otras, evaluaron la actividad productora de tiramina utilizando técnicas analíticas y moleculares. Sus resultados determinan que las 18 cepas analizadas de L. brevis enológicas, presentaron la capacidad de producir tiramina en medio de cultivo, conjuntamente lo confirmaron con la detección positiva del gen $t d c$ de las 18 cepas. Por otro lado, también Landete et al. (2007), coinciden con nuestros resultados al concluir que $L$. paracasei de origen enológico no tiene la capacidad de producir tiramina.

Un ensayo que tuvo como objetivo cuantificar la habilidad de 136 BAL aisladas del vino para producir histamina fue el realizado por Landete, Ferrer \& Pardo (2005), en el cual realizaron pruebas cualitativas en medio de cultivo y cuantitativas utilizando HPLC y métodos enzimáticos, observando que la presencia de Oenococcus oeni influye en el aumento de dicha amina con una 
producción detectada por HPLC en medio de cultivo de 5 a $99 \mathrm{mg} / \mathrm{L}$, así como también Pediococcus parvulus y Lactobacillus hilgardii, las cuales son bacterias con alto índice de producción, sintetizando más de $125 \mathrm{mg} / \mathrm{L}$. También analizaron 4 cepas de L. paracasei y 12 de L. brevis (origen enológico), observando que los resultados son comparables con los de nuestro ensayo, los cuales muestran que no existe producción de histamina por parte de estas bacterias.

En el trabajo realizado por Capozzi et al. (2011), se detecta el gen tdc en cepas de Enterococcus faecium aisladas de vino tinto, demostrando que dichas bacterias pueden expresar las enzimas que catalizan la descarboxilación de tirosina y producir tiramina, posteriormente, los mismos autores, en un ensayo in vitro, determinaron que las cepas cuentan con la capacidad de producir tiramina. Por otra parte, Bover-Cid \& Holzapfel (1999) evaluaron, entre diversas bacterias, 10 cepas de E. faecium, detectando que todas las cepas producen tiramina, y ninguna histamina, putrescina ni cadaverina. Ambas publicaciones concuerdan con los resultados obtenidos en el presente trabajo y con los de diversos autores en cepas enológicas o de otro origen alimentario (Bover-Cid et al. 2001; Marcobal et al. 2004; Coton \& Coton 2005; Marcobal, Martín-Álvarez, et al. 2006; Komprda et al. 2010; Ladero et al. 2010).

En conjunto, este trabajo inicia una investigación nacional sobre los factores que influyen en la producción de $\mathrm{AB}$ durante la vinificación, el hecho de que poco a poco los niveles de dichos compuestos sean regulados a nivel mundial pone a México en una desventaja, sin embargo, con estos resultados se pretende continuar investigando sobre la presencia de aminas en vinos, y así poder proponer técnicas que permitan reducir su contenido a niveles seguros para la salud.

La capacidad de degradar $\mathrm{AB}$ se ha investigado en especies tales como Micrococcus varians (Leuschner et al. 1998) y Staphylococcus xylosus (Martuscelli et al. 2000; Gardini et al. 2002) aisladas de embutidos, en BAL iniciadoras en ensilado de pescado (Lactobacillus curvatus y Lactobacillus sakeer) (Dapkevicius et al. 2000), en productos lácteos (Voigt \& Eitenmiller 1978) y carne (Fadda et al. 2001) así como el estudio de algunas BAL del vino pertenecientes a los géneros Lactobacillus y Pediococcus que eran capaces de degradar histamina, tiramina y putrescina en medios de cultivo (García-Ruiz et al. 2011; Capozzi et al. 2012). Esto nos abre paso para seguir investigando sobre las bacterias autóctonas del vino y su capacidad para reducir la concentración de $\mathrm{AB}$ durante el proceso de vitivinificación.

Los análisis en éste trabajo sobre la producción de $\mathrm{AB}$ fueron cualitativos, es decir, no se conoce aún la magnitud que tienen ciertas BAL para sintetizar 
dichos compuestos, es importante conocer el grado de influencia sobre la presencia de $\mathrm{AB}$ para poder determinar el riesgo que tiene la producción de un vino con los cultivos productores.

Es necesario reiterar que los efectos producidos por las $A B$ sobre los consumidores dependen en gran parte de la sensibilidad y tolerancia fisiológica que estos tengan durante el consumo de AB. Por otra parte, el consumo de vino usualmente está acompañado de otro tipo de alimentos como lo son los quesos madurados, embutidos, pescados, entre otros, que pueden contener cantidades mayores de $\mathrm{AB}$ y desatar, conjuntamente, los efectos tóxicos previamente mencionados, añadiendo que el vino contiene alto contenido alcohólico el cual inhibe las enzimas que metabolizan las $A B$ en el cuerpo $(\mathrm{N}$ metil-transferasas y amino oxidasas). Con esto se trata de enfatizar que los efectos fisiológicos causados por las $\mathrm{AB}$ no se deben únicamente a su presencia en el vino, existen otras áreas que, conjuntamente con la investigación enológica, permitirán reducir los síntomas de intoxicación en el consumidor. 
Capítulo 6 CONCLUSIONES 

Se aislaron 36 BAL mediante un medio de cultivo específico bajo condiciones selectivas, y se corroboraron sus características de Gram y producción de catalasa.

Se caracterizaron mediante MALDI/TOF-MS 12 bacterias, confirmando su identificación como ácido lácticas, de las cuales 10 fueron de origen enológico, identificando 6 cepas de la especie Enterococcus faecium, 2 de Lactobacillus brevis y 4 Lactobacillus paracasei, todas comúnmente encontradas en el proceso de vitivinificación. La utilización de dicha técnica analítica nos demuestra la practicidad, facilidad y confiabilidad de resultados para la identificación de bacterias enológicas aún y cuando existen similitudes taxonómicas entres especies, siendo una nueva tendencia tecnológica que permitirá reducir costos, tiempo y trabajo en los laboratorios durante los análisis rutinarios.

No se detectó el gen $b d c \mathrm{~A}$ en ninguna de las BAL analizadas, lo que indica que no tienen la capacidad de sintetizar la enzima HDC, la cual cataliza la reacción de descarboxilación de histidina para producir histamina. Por otra parte, tampoco se identificó el gen sufI, dicho gen codifica a una proteína (SuFI) capaz de reducir histamina.

Se demostró que en las fermentaciones realizadas con, L. brevis, L. paracasei y E. faecium, estas cepas no presentaron la capacidad de producir histamina ni putrescina.

Este trabajo demostró que la presencia de ciertas cepas de Lactobacillus brevis y Enterococcus faecium en el área enológica puede presentar ciertos riesgos en los consumidores, debido a su producción de tiramina.

La presencia de aminas biógenas en las uvas puede ser controlada mediante la reducción de las prácticas que aumentan la extracción de aminoácidos, tales como la maceración del hollejo y el contacto con las lías. Algunos parámetros enológicos pueden afectar el contenido final de aminas en el vino, es decir, los niveles enológicos de $\mathrm{pH}$ altos así como de $\mathrm{SO}_{2}$ y etanol bajos, ya que inducen la producción de $\mathrm{AB}$ mediante BAL. Es importante mencionar que las prácticas agrícolas y enológicas pueden controlar su acumulación así como la región vitícola y variedades de uva que se utilicen, ya que la composición nutrimental (aminoácidos y proteínas principalmente), es factor principal como precursor para la producción de aminas. 

BIBLIOGRAFÍA 

Alstadhaug, K.B., 2014. Review Article. Histamine in Migraine and Brain. American Headache Society, 54, pp.246-259.

Álvarez-Buylla, J.R., 1992. Efecto de la bistamina sobre el crecimiento y diferenciación celular en el cerebro de rata, Universitat Autònoma de Barcelona. Available at: http:// books.google.com.mx/books?id=XB7uuAAACAAJ.

Anl, R.E. et al., 2004. The determination of biogenic amines in Turkish red wines. Journal of Food Composition and Analysis, 17(1), pp.53-62. Available at: http://linkinghub.elsevier.com/retrieve/pii/S0889157503001042 [Accessed December 5, 2013].

Araque, I. et al., 2009. Detection of arc genes related with the ethyl carbamate precursors in wine lactic acid bacteria. Journal of Agricultural and Food Chemistry, 57(5), pp.1841-7. Available at: http://www.ncbi.nlm.nih.gov/pubmed/19219988.

Arrieta, M.P. \& Prats-Moya, M.S., 2012. Free amino acids and biogenic amines in Alicante Monastrell wines. Food Chemistry, 135(3), pp.1511-9. Available at: http://www.ncbi.nlm.nih.gov/pubmed/22953887 [Accessed November 8, 2012].

Bach, B. et al., 2012. Validation of a method for the analysis of biogenic amines: histamine instability during wine sample storage. Analytica Cbimica Acta, 732, pp.114-9. Available at: http://www.ncbi.nlm.nih.gov/pubmed/22688042 [Accessed October 15, 2012].

Bairoch, A., 2000. The ENZYME database in 2000. Nucleic acids research, 28(1), pp.304-5. Available at:

http:/ / www.pubmedcentral.nih.gov/articlerender.fcgi?artid=102465\&tool=p mcentrez\&rendertype $=$ abstract .

Barba, G. et al., 2012. Contenido de Histamina y calidad microbiológica de pescado comercializado en Mazatlán, Sinaloa. Revista de Ciencias Biológicas y de la Salud, 14(1), pp.3-12.

Bartowsky, E.J. \& Stockley, C.S., 2010. Histamine in Australian wines-a survey between 1982 and 2009. Annals of Microbiology, 61(1), pp.167-172. Available at: http://www.springerlink.com/index/10.1007/s13213-010-0070-z [Accessed October 15, 2012]. 
Battaglia, R. \& Fröhlich, D., 1978. HPLC Determination of Histamine in Wine. Journal of High Resolution Chromatography Communication, 2, pp.100-101.

Bauzaa, T. et al., 1995. Determination of biogenic amines and their precursor amino acids in wines of the Vallée du Rhône by high-performance liquid chromatography with precolumn derivatization and fluorimetric detection. Journal of Chromatography A, 707, pp.373-379.

Blouin, J. \& Peynaud, É., 2003. Enología práctica: conocimiento y elaboración del vino, Mundi-Prensa Libros. Available at: http://books.google.com.mx/books?id=C-IkDmQUkxEC.

Bover-Cid, S. et al., 2001. Amino acid-decarboxylase activity of bacteria isolated from fermented pork sausages. International journal of food microbiology, 66(3), pp.185-9. Available at: http://www.ncbi.nlm.nih.gov/pubmed/11428577.

Bover-Cid, S. \& Holzapfel, W., 1999. Improved screening procedure for biogenic amine production by lactic acid bacteria. International journal of food microbiology, 53(1), pp.33-41. Available at:

http://www.ncbi.nlm.nih.gov/pubmed/10598112.

Bravo-Ferrada, B.M. et al., 2013. Patagonian red wines: selection of Lactobacillus plantarum isolates as potential starter cultures for malolactic fermentation. World Journal of Microbiology \& Biotechnology. Available at: http://www.ncbi.nlm.nih.gov/pubmed/23546829 [Accessed August 6, 2013].

Ten Brink, B. et al., 1990. Occurrence and formation of biologically active amines in foods. International Journal of Food Microbiology, 11(1), pp.73-84. Available at: http://www.ncbi.nlm.nih.gov/pubmed/2223522.

Bruker Daltonik, 2011. Clinical Microbiology: The MALDI Biotyper System.

Buňka, F. et al., 2013. Biogenic amines occurrence in fish meat sampled from restaurants in region of Czech Republic. Food Control, 31(1), pp.49-52. Available at: http://linkinghub.elsevier.com/retrieve/pii/S0956713512005440 [Accessed February 21, 2013].

Buteau, C., Duitschaever, C. \& Ashton, G.C., 1984. A Study of the Biogenesis of Amines in a Villard Noir Wine. American Journal of Enology and Viticulture, 35(4), pp.228-236. 
Callejón, S. et al., 2013. Identification of a novel enzymatic activity from lactic acid bacteria able to degrade biogenic amines in wine. Applied Microbiology and Biotechnology. Available at: http://www.ncbi.nlm.nih.gov/pubmed/23515835 [Accessed August 6, 2013].

Capozzi, V. et al., 2012. Biogenic Amines Degradation by Lactobacillus plantarum: Toward a Potential Application in Wine. Frontiers in Microbiology, 3(April), p.122. Available at: http://www.pubmedcentral.nih.gov/articlerender.fcgi?artid=3316997\&tool= pmcentrez\&rendertype $=$ abstract [Accessed August 6, 2013].

Capozzi, V. et al., 2011. Isolation and characterization of tyramine-producing Enterococcus faecium strains from red wine. Food Microbiology, 28(3), pp.4349. Available at: http://www.ncbi.nlm.nih.gov/pubmed/21356448 [Accessed January 29, 2014].

Chang, G.W. \& Snell, E.E., 1968. Histidine Decarboxylase of Lactobacillus 30a. Purification, Substrate Specificity, and Stereospecificity. Biochemistry, 7(6), pp.2005-2012.

Chassandes, O. et al., 1994. The Human Gene for Diamine Oxidase, an Amiloride Binding Protein. The Journal of Biological Chemistry, 269(20), pp.14484-14489.

Cilliers, D. \& Van Wyk, C.J., 1985. Histamine and Tyramine Content of South African Wine. South African Journal of Enology and Viticulture, 6(2), pp.35-40.

Collins, M.D., Phillips, B.A. \& Zanoni, P., 1989. Deoxyribonucleic Acid Homology Studies of Lactobacillus casei, Lactobacillus paracasei sp. nov., subsp. paracasei and subsp. tolerans, and Lactobacillus rhamnosus sp. nov., comb. nov. International Journal of Systematic Bacteriology, 39(2), pp.105-108.

Coloretti, F. et al., 2013. Effect of wine addition on microbiological characteristics, volatile molecule profiles and biogenic amine contents in fermented sausages. Meat Science, 96(3), pp.1395-1402. Available at: http://www.ncbi.nlm.nih.gov/pubmed/24361559 [Accessed January 15, 2014].

Costantini, A. et al., 2009. Biogenic amine production by contaminating bacteria found in starter preparations used in winemaking. Journal of Agricultural and Food Chemistry, 57(22), pp.10664-9. Available at: http://www.ncbi.nlm.nih.gov/pubmed/19919115 [Accessed July 16, 2014]. 
Costantini, A. et al., 2013. Putrescine production from different amino acid precursors by lactic acid bacteria from wine and cider. International journal of food microbiology, 165(1), pp.11-7. Available at:

http://www.ncbi.nlm.nih.gov/pubmed/23685467 [Accessed August 6, 2013].

Coton, E., Rollan, G.C., Bertrand, A., et al., 1998. Histamine-Producing Lactic Acid Bacteria in Wines : Early Detection, Frequency, and Distribution. American Journal of Enology and Viticulture, 49(2), pp.199-2004.

Coton, E. \& Coton, M., 2005. Multiplex PCR for colony direct detection of Grampositive histamine- and tyramine-producing bacteria. Journal of Microbiological Methods, 63(3), pp.296-304. Available at: http://www.ncbi.nlm.nih.gov/pubmed/15935495 [Accessed August 19, 2013].

Coton, E., Rollan, G.C. \& Lonvaud-Funel, A., 1998. Histidine carboxylase of Leuconostoc oenos 9204 : purification, kinetic properties , cloning and nucleotide sequence of the hdc gene. Journal of Applied Microbiology, 84(2), pp.143-151.

Coton, M. et al., 2010. Occurrence of biogenic amine-forming lactic acid bacteria in wine and cider. Food Microbiology, 27(8), pp.1078-85. Available at: http://www.ncbi.nlm.nih.gov/pubmed/20832688 [Accessed February 19, 2013].

Cueva, C. et al., 2012. Degradation of biogenic amines by vineyard ecosystem fungi. Potential use in winemaking. Journal of Applied Microbiology, 112(4), pp.672-82. Available at: http://www.ncbi.nlm.nih.gov/pubmed/22268845 [Accessed October 9, 2012].

Dale, H.H. \& Laidlaw, P.P., 1910. The Physiological action of Beta-IminazolylEthylamine. The Journal of Physiology, 41(5), pp.318-344.

Dapkevicius, M.L.N.E. et al., 2000. Biogenic amine formation and degradation by potential fish silage starter microorganisms. International Journal of Food Microbiology, 57(1-2), pp.107-114. Available at: http://linkinghub.elsevier.com/retrieve/pii/S0168160500002385.

Davis, C. et al., 1988. Properties of Wine Lactic Acid Bacteria : Their Potential Enological Significance. American Journal of Enology and Viticulture, 39(2), pp.137-142. 
Demirev, P.A. et al., 1999. Microorganism identification by mass spectrometry and protein database searches. Analytical chemistry, 71(14), pp.2732-8. Available at: http://www.ncbi.nlm.nih.gov/pubmed/12462601.

Díaz, M., 2012. Aislamiento, identificación y caracterización de bacterias productoras de bistamina en queso.

Dicks, L.M.T. \& Endo, A., 2009. Taxonomic Status of Lactic Acid Bacteria in Wine and Key Characteristics to Differentiate Species. South African Journal of Enology and Viticulture, 30(1), pp.72-90.

EFSA, P. on B.H. (BIOHAZ), 2011. Scientific Opinion on risk based control of biogenic amine formation in fermented foods. EFS A Journal, 9(10), pp.1-93.

Fadda, S., Vignolo, G. \& Oliver, G., 2001. Tyramine degradation and tyramine / histamine production by lactic acid bacteria and Kocuria strains. Biotechnology Letters, 23, pp.2015-2019.

Fernández, M. et al., 2007. Factors affecting tyramine production in Enterococcus durans IPLA 655. Applied Microbiology and Biotechnology, 73(6), pp.1400-6. Available at: http://www.ncbi.nlm.nih.gov/pubmed/17043827 [Accessed January 30, 2014].

García, P. et al., 2012. Identificación bacteriana basada en el espectro de masas de proteínas: Una nueva mirada a la microbiología del siglo XXI. Revista Chilena de Infectología, 29(3), pp.263-272.

García-Moruno, E. \& Muñoz, R., 2012. Does Oenococcus oeni produce histamine? International Journal of Food Microbiology, 157(2), pp.121-9. Available at: http://www.ncbi.nlm.nih.gov/pubmed/22652194 [Accessed February 21, 2013].

García-Ruiz, A. et al., 2009. Inactivation of oenological lactic acid bacteria (Lactobacillus hilgardii and Pediococcus pentosaceus) by wine phenolic compounds. Journal of Applied Microbiology, 107(3), pp.1042-53. Available at: http://www.ncbi.nlm.nih.gov/pubmed/19486417 [Accessed July 18, 2014].

García-Ruiz, A. et al., 2011. Potential of wine-associated lactic acid bacteria to degrade biogenic amines. International Journal of Food Microbiology, 148(2), pp.115-20. Available at: http://www.ncbi.nlm.nih.gov/pubmed/21641669 [Accessed February 21, 2013]. 
Gardini, F. et al., 2005. Factors influencing biogenic amine production by a strain of Oenococcus oeni in a model system. Food Control, 16(7), pp.609-616. Available at: http://linkinghub.elsevier.com/retrieve/pii/S0956713504001434 [Accessed January 30, 2014].

Gardini, F. et al., 2002. Use of Staphylococcus xylosus as a starter culture in dried sausages: effect on the biogenic amine content. Meat Science, 61(3), pp.275-83. Available at: http://www.ncbi.nlm.nih.gov/pubmed/22060850.

Glória, B. et al., 1998. A Survey of Biogenic Amines in Oregon Pinot noir and Cabernet Sauvignon Wines. American Journal of Enology and Viticulture, 49(3), pp.279-282.

Gómez Alonso, S., Hermosín-Gutierrez \& García Romero, E., 2007. Simultaneous HPLC Analysis of Biogenic Amines, Amino Acids, and Ammonium Ion as Aminoenone Derivatives in Wine and Beer Samples. Journal of Agricultural and Food Chemistry, 55(13), pp.608-613.

González-Arenzana, L. et al., 2012. Dynamics of indigenous lactic acid bacteria populations in wine fermentations from La Rioja (Spain) during three vintages. Microbial Ecology, 63(1), pp.12-9. Available at: http://www.ncbi.nlm.nih.gov/pubmed/21779812 [Accessed February 19, 2013].

González-Marco, A. \& Ancín-Azpilicueta, C., 2006. Influence of Lees Contact on Evolution of Amines in Chardonnay Wine. Journal of Food Science, 71(9), pp.C544-C548. Available at: http://doi.wiley.com/10.1111/j.17503841.2006.00182.x [Accessed March 6, 2014].

Van de Guchte, M. et al., 2002. Stress responses in lactic acid bacteria. Antonie van Leeuwenhoek, 82, pp.187-216.

Guerrini, S. et al., 2002. Biogenic amine production by Oenococcus oeni. Current Microbiology, 44(5), pp.374-8. Available at:

http://www.ncbi.nlm.nih.gov/pubmed/11927990 [Accessed February 12, 2013].

Haag, A.M. et al., 1998. Rapid identification and speciation of Haemophilus bacteria by matrix-assisted laser desorption/ionization time-of-flight mass spectrometry. Journal of Mass Spectrometry, 33(8), pp.750-6. Available at: http://www.ncbi.nlm.nih.gov/pubmed/9745723. 
Henríquez-Aedo, K. et al., 2012. Evaluation of biogenic amines content in chilean reserve varietal wines. Food and Chemical Toxicology, 50(8), pp.2742-50. Available at: http://www.ncbi.nlm.nih.gov/pubmed/22640936 [Accessed February 21, 2013].

Herbert, P. et al., 2005. Free amino acids and biogenic amines in wines and musts from the Alentejo region. Evolution of amines during alcoholic fermentation and relationship with variety, sub-region and vintage. Journal of Food Engineering, 66(3), pp.315-322. Available at:

http://linkinghub.elsevier.com/retrieve/pii/S0260877404001542 [Accessed August 6, 2013].

Hernández-Orte, P. et al., 2008. Biogenic amine determination in wine fermented in oak barrels: Factors affecting formation. Food Research International, 41(7), pp.697-706. Available at:

http://linkinghub.elsevier.com/retrieve/pii/S0963996908000963 [Accessed October 15, 2012].

Ho, Y.-P. \& Reddy, P.M., 2010. Identification of pathogens by mass spectrometry. Clinical chemistry, 56(4), pp.525-36. Available at: http://www.ncbi.nlm.nih.gov/pubmed/20167691 [Accessed January 20, 2014].

Hsieh, S.-Y. et al., 2008. Highly efficient classification and identification of human pathogenic bacteria by MALDI-TOF MS. Molecular \& Cellular Proteomics, 7(2), pp.448-56. Available at: http://www.ncbi.nlm.nih.gov/pubmed/18045801 [Accessed January 9, 2014].

Iñiguez Crespo, M. \& Vázquez Lasa, M.B., 1994. Determination of Biogenic Amines and Other Amines in Wine by an Optimized HPLC Method With Polarity Gradient Elution. American Journal of Enology and Viticulture, 45(4), pp.460-463.

Izquierdo Cañas, P.M. et al., 2009. Biogenic amine production by Oenococcus oeni isolates from malolactic fermentation of Tempranillo wine. Journal of Food Protection, 72, pp.907-910.

Izquierdo-Pulido, M., Mariné-Font, A. \& Vidal-Carou, M. del C., 2000. Effect of tyrosine on tyramine formation during beer fermentation. Food Chemistry, 70, pp.329-332. 
Izquierdo-Pulido, M., Vidal-Carou, M. del C. \& Mariné-Font, A., 1991. Histamine and tyramine in beers. Changes during brewing of a Spanish beer. Food Chemistry, 42(2), pp.231-237. Available at: http://linkinghub.elsevier.com/retrieve/pii/030881469190037O.

Izquierdo-Pulido, M., Vidal-Carou, M. del C. \& Mariné-Font, A., 1989. Histamine and tyramine in beers: Contents and relationships with other analytical data. Journal of Food Composition and Analysis, 2(3), pp.219-227. Available at: http://linkinghub.elsevier.com/retrieve/pii/0889157589900197.

Le Jeune, C. et al., 1995. Development of a detection system for histidine decarboxylating lactic acid bacteria on DNA probes, PCR and activity test. Journal of Applied Bacteriology, 78, pp.316-326.

Jones, B.L. \& Kearns, G.L., 2011. Histamine: new thoughts about a familiar mediator. Clinical Pharmacology and Therapeutics, 89(2), pp.189-97. Available at: http://www.ncbi.nlm.nih.gov/pubmed/21178984 [Accessed November 25, 2013].

Jordana-Lluch, E., Martró Català, E. \& Ausina Ruiz, V., 2012. [Mass spectrometry in the clinical microbiology laboratory]. Enfermedades Infecciosas y Microbiología Clínica, 30(10), pp.635-44. Available at:

http://www.ncbi.nlm.nih.gov/pubmed/22381225 [Accessed January 30, 2014].

Jørgensen, E. et al., 2007. Histamine and the Regulation of Body Weight. Neuroendocrinology, 86(3), pp.210-214. Available at:

http://www.karger.com/DOI/10.1159/000108341.

Kalač, P., Svecová, S. \& Pelikánová, T., 2002. Levels of biogenic amines in typical vegetable products. Food Chemistry, 77, pp.349-351.

Kandler, O., 1983. Carbohydrate metabolism in lactic acid bacteria. Antonie van Leeuwenhoek, 49, pp.209-224.

Kanny, G. et al., 2001. No correlation between wine intolerance and histamine content of wine. The Journal of Allergy and Clinical Immunology, 107(2), pp.375-8. Available at: http://www.ncbi.nlm.nih.gov/pubmed/11174207 [Accessed March 25, 2014].

Kibbe, W. a, 2007. OligoCalc: an online oligonucleotide properties calculator. Nucleic Acids Research, 35(Web Server issue), pp.W43-6. Available at: 
http://www.pubmedcentral.nih.gov/articlerender.fcgi?artid=1933198\&tool= pmcentrez\&rendertype $=$ abstract $[$ Accessed July 16, 2014].

Komprda, T. et al., 2010. Tyrosine- and histidine-decarboxylase positive lactic acid bacteria and enterococci in dry fermented sausages. Meat Science, 86(3), pp.870-877. Available at: http://dx.doi.org/10.1016/j.meatsci.2010.07.013.

König, H., Unden, G. \& Fröhlich, J., 2009. Biology of Microorganisms on Grapes, in Must and in Wine H. König, G. Unden, \& J. Fröhlich, eds., Berlin, Heidelberg: Springer Berlin Heidelberg. Available at: http://link.springer.com/10.1007/978-3-540-85463-0.

Konno, R. \& Yasumura, Y., 1992. D-Amino-Acid Oxidase an its Physiological Function. International Journal of Biochemistry, 2(4), pp.519-524.

Ladero, V. et al., 2010. Quantitative detection and identification of tyramineproducing enterococci and lactobacilli in cheese by multiplex qPCR. Food Microbiology, 27(7), pp.933-9. Available at:

http://www.ncbi.nlm.nih.gov/pubmed/20688235 [Accessed January 29, 2014].

Lafon Lafourcade, S., 1983. Wine and Brandy. In G. Reed, ed. Biotechnology. weinheim, pp. 81-163.

Landete, J.M., Ferrer, S., Polo, L., et al., 2005. Biogenic Amines in Wines from Three Spanish Regions. Journal of Agricultural and Food Chemistry, 53, pp.11191124.

Landete, J.M., 2005. Estudio y caracterización molecular de la producción de aminas biógenas por parte de bacterias lácticas de origen enológico.

Landete, J.M. et al., 2010. PCR methods for the detection of biogenic amineproducing bacteria on wine. Annals of Microbiology, 61(1), pp.159-166. Available at: http://link.springer.com/10.1007/s13213-010-0068-6 [Accessed November 14, 2013].

Landete, J.M., Ferrer, S. \& Pardo, I., 2004. Improved enzymatic method for the rapid determination of histamine in wine. Food Additives and Contaminants, 21(12), pp.1149-1154. Available at: http://www.tandfonline.com/doi/abs/10.1080/02652030400019737 [Accessed August 6, 2013]. 
Landete, J.M., Ferrer, S. \& Pardo, I., 2005. Which lactic acid bacteria are responsible for histamine production in wine? Journal of Applied Microbiology, 99(3), pp.580-6. Available at:

http://www.ncbi.nlm.nih.gov/pubmed/16108800 [Accessed October 15, 2012].

Landete, J.M., Pardo, I. \& Ferrer, S., 2007. Tyramine and phenylethylamine production among lactic acid bacteria isolated from wine. International Journal of Food Microbiology, 115(3), pp.364-8. Available at:

http://www.ncbi.nlm.nih.gov/pubmed/17307265 [Accessed February 21, 2013].

Lay, J.O., 2002. MALDI-TOF mass spectrometry of bacteria. Mass Spectrometry Reviews, 20(4), pp.172-94. Available at: http://www.ncbi.nlm.nih.gov/pubmed/11835305 [Accessed January 10, 2014].

Legarraga, P. et al., 2013. Impacto de la espectrometría de masas por MALDI-TOF MS en la identificación rápida de bacterias aeróbicas y anaeróbicas de importancia clínica. Revista Chilena de Infectología, 30(2), pp.140-146.

Lehtonen, P., 1996. Determination of Amines and Amino Acids in Wine -- A Review. American Journal of Enology and Viticulture, 47(2), pp.127-133.

Leitão, M.C., Marques, A.P. \& San Romão, M. V., 2005. A survey of biogenic amines in commercial Portuguese wines. Food Control, 16(3), pp.199-204. Available at: http://linkinghub.elsevier.com/retrieve/pii/S0956713504000167 [Accessed December 5, 2013].

Leuschner, R.G., Heidel, M. \& Hammes, W.P., 1998. Histamine and tyramine degradation by food fermenting microorganisms. International Journal of Food Microbiology, 39, pp.1-10.

Linares, D.M. et al., 2011. Biogenic amines in dairy products. Critical Reviews in Food Science and Nutrition, 51(7), pp.691-703. Available at: http://www.ncbi.nlm.nih.gov/pubmed/21793728 [Accessed February 5, 2014].

Lonvaud-Funel, A., 2001. Biogenic amines in wines: role of lactic acid bacteria. FEMS Microbiology Letters, 199(1), pp.9-13. Available at: http://www.ncbi.nlm.nih.gov/pubmed/11356560. 
Lonvaud-funel, A., 1999. Lactic acid bacteria in the quality improvement and depreciation of wine. Antonie van Leeuwenhoek, 76, pp.317-331.

Lonvaud-Funel, A. \& Joyeux, A., 1994. Histamine production by wine lactic acid bacteria: Isolation of a histamine-producing strain of Leuconostoc oenos. Journal of Applied Bacteriology, 77, pp.401-407.

López, E., 2007. Brettanomyces/Dekkera: Control y detección en bodegas. ACE Revista de Enología, 78.

Lucas, P. et al., 2005. Histamine-Producing Pathway Encoded on an Unstable Plasmid in Lactobacillus hilgardii 0006. Applied and Environmental Microbiology, 71(3), pp.1417-1424.

Lucas, P. et al., 2003. The tyrosine decarboxylase operon of Lactobacillus brevis IOEB 9809: characterization and conservation in tyramine-producing bacteria. FEMS Microbiology Letters, 229(1), pp.65-71. Available at: http://doi.wiley.com/10.1016/S0378-1097(03)00787-0 [Accessed January 29, 2014].

Lucas, P., Claisse, O. \& Lonvaud-Funel, A., 2008. High frequency of histamineproducing bacteria in the enological environment and instability of the histidine decarboxylase production phenotype. Applied and Environmental Microbiology, 74(3), pp.811-7. Available at: http://www.pubmedcentral.nih.gov/articlerender.fcgi?artid=2227711\&tool= pmcentrez\&rendertype $=$ abstract $[$ Accessed June 4, 2013].

Madigan, M., Martinko, J. \& Parker, J., 2003. Biología de los Microorganismos: Brock 10th ed. P. H. Pearson, ed.,

Maijala, R.L., 1993. Formation of histamine and tyramine by some lactic acid bacteria in MRS-broth and modified decarboxylation agar. Letters in Applied Microbiology, 17, pp.40-43.

Maintz, L. \& Novak, N., 2007. Histamine and histamine intolerance. The American Journal of Clinical Nutrition, 85(5), pp.1185-1196. Available at: http://www.ncbi.nlm.nih.gov/pubmed/17490952.

De Man, J.C., Rogosa, M. \& Sharpe, M.E., 1960. A Medium for the Cultivation of Lactobacilli. Journal of Applied Microbiology, 23(1), pp.130-135. Available at: http://doi.wiley.com/10.1111/j.1365-2672.1960.tb00188.x. 
Marcobal, Á., Martín-Álvarez, P.J., et al., 2006. A multifactorial design for studying factors influencing growth and tyramine production of the lactic acid bacteria Lactobacillus brevis CECT 4669 and Enterococcus faecium BIFI-58. Research in Microbiology, 157(5), pp.417-24. Available at: http://www.ncbi.nlm.nih.gov/pubmed/16488576 [Accessed January 29, 2014].

Marcobal, Á. et al., 2005. Biogenic amine content of red Spanish wines: comparison of a direct ELISA and an HPLC method for the determination of histamine in wines. Food Research International, 38(4), pp.387-394. Available at: http://linkinghub.elsevier.com/retrieve/pii/S0963996904002285 [Accessed September 6, 2013].

Marcobal, Á. et al., 2004. The Tyrosine Decarboxylation Test Does Not Differentiate Enterococcus faecalis from Enterococcus faecium. Systematic and Applied Microbiology, 27, pp.423-426.

Marcobal, Á., de las Rivas, B. \& Muñoz, R., 2006. Methods for the Detection of Bacteria Producing Biogenic Amines on Foods: A Survey. Journal für Verbraucherschutz und Lebensmittelsicherheit, 1(3), pp.187-196. Available at: http://www.springerlink.com/index/10.1007/s00003-006-0035-0 [Accessed February 21, 2013].

Marquardt, P. \& Werringloer, H.W., 1965. Toxicity of wine. Food and Cosmetics Toxicology, 3(5), pp.803-10. Available at: http://www.ncbi.nlm.nih.gov/pubmed/20510887.

Marques, A.P., Leitão, M.C. \& San Romão, M. V., 2008. Biogenic amines in wines: Influence of oenological factors. Food Chemistry, 107(2), pp.853-860. Available at: http://linkinghub.elsevier.com/retrieve/pii/S0308814607009193 [Accessed October 15, 2012].

Martín-Álvarez, P.J. et al., 2005. Influence of technological practices on biogenic amine contents in red wines. European Food Research and Technology, 222(3-4), pp.420-424. Available at: http://www.springerlink.com/index/10.1007/s00217-005-0142-7 [Accessed February 21, 2013].

Martuscelli, M. et al., 2000. Biogenic amine formation and oxidation by Staphylococcus xylosus strains from artisanal fermented sausages. Letters in 
Applied Microbiology, 31(3), pp.228-32. Available at:

http://www.ncbi.nlm.nih.gov/pubmed/10972734.

Martuscelli, M. et al., 2013. Biogenic amines content as a measure of the quality of wines of Abruzzo (Italy). Food Chemistry, 140(3), pp.590-5977. Available at: http://linkinghub.elsevier.com/retrieve/pii/S0308814613000101 [Accessed February 21, 2013].

Mazé, A. et al., 2010. Complete genome sequence of the probiotic Lactobacillus casei strain BL23. Joumal of Bacteriology, 192(10), pp.2647-8. Available at: http:/ /www.pubmedcentral.nih.gov/articlerender.fcgi?artid=2863562\&tool= pmcentrez\&rendertype $=$ abstract [Accessed July 16, 2014].

Moreno-Arribas, M.V. et al., 2000. Isolation, properties and behaviour of tyramineproducing lactic acid bacteria from wine. Journal of Applied Microbiology, 88(4), pp.584-93. Available at: http://www.ncbi.nlm.nih.gov/pubmed/10792516.

Moreno-Arribas, M.V. et al., 2003. Screening of biogenic amine production by lactic acid bacteria isolated from grape must and wine. International Journal of Food Microbiology, 84(1), pp.117-123. Available at:

http://linkinghub.elsevier.com/retrieve/pii/S0168160502003914 [Accessed February 28, 2013].

Moreno-Arribas, M.V. \& Lonvaud-Funel, A., 1999. Tyrosine decarboxylase activity of Lactobacillus brevis IOEB 9809 isolated from wine and L. brevis ATCC 367. FEMS Microbiology Letters, 180(1), pp.55-60. Available at: http://doi.wiley.com/10.1016/S0378-1097(99)00460-7.

Moreno-Arribas, M.V. \& Polo, M.C., 2009. Chapter 6A Amino Acids and Biogenic Amines. In Wine Chemistry and Biochemistry. pp. 163-189.

Moreno-Arribas, M.V. \& Polo, M.C., 2008. Occurrence of lactic acid bacteria and biogenic amines in biologically aged wines. Food Microbiology, 25(7), pp.875-81. Available at: http://www.ncbi.nlm.nih.gov/pubmed/18721676 [Accessed October 15, 2012].

Moret, S. et al., 2005. A survey on free biogenic amine content of fresh and preserved vegetables. Food Chemistry, 89, pp.355-361.

Mtshali, P.S. et al., 2010. Genetic screening of wine-related enzymes in Lactobacillus species isolated from South African wines. Journal of Applied Microbiology, 108(4), pp.1389-97. Available at: 
http://www.ncbi.nlm.nih.gov/pubmed/19793136 [Accessed January 29, 2014].

Nannelli, F. et al., 2008. Determination of lactic acid bacteria producing biogenic amines in wine by quantitative PCR methods. Letters in Applied Microbiology, 47, pp.594-599.

Nout, M.J.R., 1994. Fermented foods and food safety. Food Research International, 27(3), pp.291-298. Available at:

http://www.sciencedirect.com/science/article/pii/0963996994900973 [Accessed July 21, 2014].

Novella-Rodríguez, S. et al., 2002. Profile of Biogenic Amines in Goat Cheese Made from Pasteurized and Pressurized Milks. Food Chemistry and Toxicology, 67(8), pp.2940-2944.

OIV/OENO 206/2010, 2010. RESOLUCIÓN OIV/OENO 206/2010 Análisis microbiológico del vino y del mosto,

Ojala, T. et al., 2010. Genome sequence of Lactobacillus crispatus ST1. Journal of Bacteriology, 192(13), pp.3547-8. Available at:

http://www.pubmedcentral.nih.gov/articlerender.fcgi?artid=2897677\&tool= pmcentrez\&rendertype $=$ abstract [Accessed July 16, 2014].

Önal, A., Tekkeli, S.E.K. \& Önal, C., 2013. A review of the liquid chromatographic methods for the determination of biogenic amines in foods. Food Chemistry, 138(1), pp.509-15. Available at: http://www.ncbi.nlm.nih.gov/pubmed/23265518 [Accessed January 30, 2013].

Osborne, J.P. \& Edwards, C.G., 2005. Bacteria important during winemaking. Advances in food and nutrition research, 50(05), pp.139-77. Available at: http://www.ncbi.nlm.nih.gov/pubmed/16263430 [Accessed April 1, 2013].

Ough, C.S., 1971. Measurement Histamine in California Wines. Journal of Agricultural and Food Chemistry, 19(2), pp.241-244.

Ough, C.S., 1996. Tratado Básico de Enología, Acribia, Editorial, S.A. Available at: http://books.google.com.mx/books?id=ySffAAAACAAJ. 
Palacios, A. et al., 2005. Influencia organoléptica de las aminas biógenas producidas durante la fermentación maloláctica del vino. ACE Revista de Enología, 70, pp.14-20.

Petri, A. et al., 2013. Fast identification of wine related lactic acid bacteria by multiplex PCR. Food Microbiology, 33(1), pp.48-54. Available at: http://www.ncbi.nlm.nih.gov/pubmed/23122500 [Accessed March 5, 2013].

Peynaud, É., 1977. Enología Práctica: Conocimiento y elaboración del vino, Madrid, España: Mundi-Prensa.

Pramateftaki, P. V. et al., 2006. Evolution of malolactic bacteria and biogenic amines during spontaneous malolactic fermentations in a Greek winery. Letters in Applied Microbiology, 43(2), pp.155-60. Available at: http://www.ncbi.nlm.nih.gov/pubmed/16869898 [Accessed January 21, 2014].

Proestos, C., Loukatos, P. \& Komaitis, M., 2008. Determination of biogenic amines in wines by HPLC with precolumn dansylation and fluorimetric detection. Food Chemistry, 106(3), pp.1218-1224. Available at: http://linkinghub.elsevier.com/retrieve/pii/S0308814607006413 [Accessed October 15, 2012].

Quevauviller, A. \& Mazière, M.A., 1969. Recherche et dosage biologique de l'histamine dans les vins. Annales Pharmaceutiques Françaises, 27(6), pp.411-414.

Restuccia, D. et al., 2011. A new method for the determination of biogenic amines in cheese by LC with evaporative light scattering detector. Talanta, 85(1), pp.363-9. Available at: http://www.ncbi.nlm.nih.gov/pubmed/21645711 [Accessed October 15, 2012].

Riley, W.D. \& Snell, E.E., 1968. Histidine Decarboxylase of Lactobacillus 30a. The Presence of Covalently Bound Pyruvate as the Prosthetic Group. Biochemistry, 7(10), pp.3520-3528.

Rodas, A.M. et al., 2003. 16S-ARDRA, a Tool for Identification of Lactic Acid Bacteria Isolated from Grape Must and Wine. Systematic and Applied Microbiology, 26(3), pp.412-422. Available at: http://www.ncbi.nlm.nih.gov/pubmed/14529184.

Rodas, A.M., Ferrer, S. \& Pardo, I., 2005. Polyphasic study of wine Lactobacillus strains: taxonomic implications. International Journal of Systematic and Evolutionary 
Microbiology, 55(Pt 1), pp.197-207. Available at:

http://www.ncbi.nlm.nih.gov/pubmed/15653876 [Accessed January 29, 2014].

Romano, A. et al., 2012. Evidence of two functionally distinct ornithine decarboxylation systems in lactic acid bacteria. Applied and Environmental Microbiology, 78(6), pp.1953-61. Available at:

http://www.pubmedcentral.nih.gov/articlerender.fcgi?artid=3298143\&tool= pmcentrez\&rendertype $=$ abstract [Accessed July 17, 2014].

Romano, A. et al., 2014. Putrescine production via the ornithine decarboxylation pathway improves the acid stress survival of Lactobacillus brevis and is part of a horizontally transferred acid resistance locus. International Journal of Food Microbiology. Available at:

http://linkinghub.elsevier.com/retrieve/pii/S0168160514000373 [Accessed January 29, 2014].

De Rosa, T., 1988. Tecnología del vino tinto, Mundi-Prensa Libros, S.A. Available at: http://books.google.com.mx/books?id=g2GaPQAACAAJ.

Rosenthaler, J. et al., 1965. Purification and Properties of Histidine Decarboxylase from Lactobacillus 30a. Biochemistry, 54, pp.152-158.

Rundberget, T., Skaar, I. \& Flåøyen, A., 2004. The presence of Penicillium and Penicillium mycotoxins in food wastes. International Journal of Food Microbiology, 90(2), pp.181-188. Available at:

http://linkinghub.elsevier.com/retrieve/pii/S0168160503002915 [Accessed June 20, 2014].

Sauer, S. et al., 2008. Classification and identification of bacteria by mass spectrometry and computational analysis. PloS one, 3(7), p.e2843. Available at: http://www.pubmedcentral.nih.gov/articlerender.fcgi?artid=2475672\&tool= pmcentrez\&rendertype $=$ abstract [Accessed January 20, 2014].

Sauer, S. \& Kliem, M., 2010. Mass spectrometry tools for the classification and identification of bacteria. Nature reviews. Microbiology, 8(1), pp.74-82. Available at: http://www.ncbi.nlm.nih.gov/pubmed/20010952 [Accessed January 15, 2014].

Schelp, E. et al., 2001. pH-induced structural changes regulate histidine decarboxylase activity in Lactobacillus 30a. Journal of Molecular Biology, 306(4), 
pp.727-32. Available at: http://www.ncbi.nlm.nih.gov/pubmed/11243783 [Accessed November 25, 2013].

Schirone, M. et al., 2013. High content of biogenic amines in Pecorino cheeses. Food Microbiology, 34(1), pp.137-144. Available at:

http://linkinghub.elsevier.com/retrieve/pii/S0740002012002663 [Accessed February 21, 2013].

Schlegel, H.G., 1997. Microbiología General Séptima. OMEGA, ed., Barcelona, España.

Schwelberger, H.G. \& Bodner, E., 1997. Purification and characterization of diamine oxidase from porcine kidney and intestine. Biochimica et Biophysica Acta, 1340, pp.152-164.

Shalaby, A.R., 1997. Significance of biogenic amines to food safety and human health. Food Research International, 29(7), pp.675-690.

Silla Santos, M.H., 1996. Biogenic amines: their importance in foods. International Journal of Food Microbiology, 29(2-3), pp.213-31. Available at: http://www.ncbi.nlm.nih.gov/pubmed/8796424.

Smit, A.Y. et al., 2013. Evaluating the influence of maceration practices on biogenic amine formation in wine. LWT - Food Science and Technology, 53(1), pp.297-307. Available at: http://linkinghub.elsevier.com/retrieve/pii/S0023643813000078 [Accessed December 9, 2013].

Smit, A.Y. \& du Toit, M., 2011. Evaluating the Influence of Malolactic Fermentation Inoculation Practices and Ageing on Lees on Biogenic Amine Production in Wine. Food and Bioprocess Technology, 6(1), pp.198-206. Available at: http://www.springerlink.com/index/10.1007/s11947-011-0702-8 [Accessed February 21, 2013].

Snell, E.E., 1990. Vitamin B6 and decarboxylation of histidine. Annals of the New York. Academy of Sciences, 585, pp.1-12. Available at: http://www.ncbi.nlm.nih.gov/pubmed/2192605.

Soufleros, E.H. et al., 2007. Determination of biogenic amines in Greek wines by HPLC and ultraviolet detection after dansylation and examination of factors affecting their presence and concentration. Food Chemistry, 101(2), pp.704-716. 
Available at: http://linkinghub.elsevier.com/retrieve/pii/S0308814606001427 [Accessed October 15, 2012].

Soufleros, E.H., Barrios, M.-L. \& Bertrand, A., 1998. Correlation between the content of Biogenic Amines and other Wine compounds. American Journal of Enology and Viticulture, 49, pp.266-277.

Straub, B.W. et al., 1995. The formation of biogenie amines by fermentation organisms. Z Lebensm Unters Forsch, 201, pp.79-82.

Suárez, J.A. \& Íñigo, B., 2004. Microbiología enológica: fundamentos de vinificación, Ediciones Mundi-Prensa. Available at: http://books.google.com.mx/books?id=w6znd1plFtAC.

Subden, R.E. et al., 1979. Histamine content of Canadian wines determined by Reverse Phase High Performance Liquid Chromatografy. American Journal of Enology and Viticulture, 30(1), pp.19-21.

Sun, Z. et al., 2011. Complete genome sequence of Lactobacillus delbrueckii subsp. bulgaricus strain ND02. Journal of Bacteriology, 193(13), pp.3426-7. Available at: http://www.pubmedcentral.nih.gov/articlerender.fcgi?artid=3133281\&tool= pmcentrez\&rendertype $=$ abstract [Accessed July 16, 2014].

Thomsen, L.L. \& Olesen, J., 2001. Nitric oxide in primary headaches. Current Opinion in Neurology, 14(3), pp.315-21. Available at: http://www.ncbi.nlm.nih.gov/pubmed/11371754.

Vázquez Lasa, M.B. et al., 1998. Biogenic Amines in Rioja Wines. American Journal of Enology and Viticulture, 49(3), p.229.

Verde-Calvo, J.R., 2004. Efecto de la fermentación maloláctica sobre la edad química de un vino tinto Cabernet Sauvignon en diferentes condiciones de añejamiento. Revista Mexicana de Ingeniería Química, 3, pp.265-272.

Vidal-Carou, M. del C. et al., 1989. Histamine and Tyramine in Natural Sparkling Wine, Vermouth, Cider and Vinegar. Journal of Food Composition and Analysis, 18, pp.210-218.

Vidal-Carou, M. del C. et al., 1990. Histamine and Tyramine in Spanish Wines: Their Formation During the Winemaking Process. American Journal of Enology and Viticulture, 41(2), pp.160-167. 
Vidal-Carou, M. del C., Codony-Salcedo, R. \& Meriné-Font, A., 1991. Changes in the Concentration of Histamine and Tyramine During Wine Spoilage at Various Temperatures. American Journal of Enology and Viticulture, 42(2), pp.145149.

Voigt, M.N. \& Eitenmiller, R.R., 1978. Role of Histidine and Tyrosine Decarboxylases and Mono- and Diamine Oxidases in Amine Build-Up in Cheese. Journal of Food Protection, 41(3), pp.182-186.

Wang, Y. et al., 2011. Complete genome sequence of the probiotic Lactobacillus plantarum ST-III. Journal of Bacteriology, 193(1), pp.313-4. Available at: http://www.pubmedcentral.nih.gov/articlerender.fcgi?artid=3019943\&tool= pmcentrez\&rendertype $=$ abstract [Accessed July 16, 2014].

Ward, L.J.H. \& Timmins, M.J., 1999. Differentiation of Lactobacillus casei, Lactobacillus paracasei and Lactobacillus rhamnosus by polymerase chain reaction. Letters in Applied Microbiology, 29, pp.90-92.

Yildirim, H.K., Üren, A. \& Ufuk, Y., 2007. Evaluation of Biogenic Amines in Organic and Non-Organic Wines by HPLC OPA Derivatization. Food Technology and Biotechnology, 45(1), pp.62-68.

Yongsawatdigul, J., Rodtong, S. \& Raksakulthai, N., 2007. Acceleration of Thai fish sauce fermentation using proteinases and bacterial starter cultures. Journal of Food Science, 72(9), pp.M382-90. Available at:

http://www.ncbi.nlm.nih.gov/pubmed/18034732 [Accessed May 27, 2014].

Zee, J.A. et al., 1983. Biogenic Amines in Wines. American Journal of Enology and Viticulture, 34(1), pp.6-9.

Zee, J.A., Simard, R.E. \& Roy, A., 1981. A Modified Automated Ion-Exchange Method for the Separation and Quantitation of Biogenic Amines. Canadian Institute of Food and Technology, 14(1), pp.71-75.

Zhang, Z.-Y. et al., 2009. Complete genome sequence of Lactobacillus plantarum JDM1. Journal of Bacteriology, 191(15), pp.5020-1. Available at:

http://www.pubmedcentral.nih.gov/articlerender.fcgi?artid=2715720\&tool= pmcentrez\&rendertype $=$ abstract [Accessed July 16, 2014].

Zhijun, L. et al., 2007. A survey of biogenic amines in chinese red wines. Food Chemistry, 105(4), pp.1530-1535. Available at: 
http://linkinghub.elsevier.com/retrieve/pii/S0308814607004566 [Accessed October 15, 2012]. 